Georgia State University

ScholarWorks @ Georgia State University

$11-28-2007$

\title{
Trauma Exposure and Behavioral Outcomes in Sheltered Homeless Children: The Moderating Role of Perceived Social Support
}

Beryl Ann Cowan

Georgia State University

Follow this and additional works at: https://scholarworks.gsu.edu/psych_diss

Part of the Psychology Commons

\section{Recommended Citation}

Cowan, Beryl Ann, "Trauma Exposure and Behavioral Outcomes in Sheltered Homeless Children: The Moderating Role of Perceived Social Support." Dissertation, Georgia State University, 2007.

doi: https://doi.org/10.57709/1059917

This Dissertation is brought to you for free and open access by the Department of Psychology at ScholarWorks @ Georgia State University. It has been accepted for inclusion in Psychology Dissertations by an authorized administrator of ScholarWorks @ Georgia State University. For more information, please contact scholarworks@gsu.edu. 


\title{
TRAUMA EXPOSURE AND BEHAVIORAL OUTCOMES IN SHELTERED HOMELESS CHILDREN: \\ THE MODERATING ROLE OF PERCEIVED SOCIAL SUPPORT
}

\author{
by \\ BERYL ANN COWAN, J.D., M.A. \\ Under the Direction of Gabriel Kuperminc Ph.D. and Gregory Jurkovic, Ph.D.
}

\begin{abstract}
This study examined the association between traumatic exposure and mental health outcomes in sheltered homeless children. Also investigated was the moderating role of perceived social support in the pathway between traumatic exposure and emotional distress. Trauma exposure was conceptualized in two ways: first through lifetime exposures to abuse, neglect, negative peers, community and interpersonal violence, and the loss of significant attachment figures, and; second through highly stressful events that occur specifically in the context of homelessness. Mental health outcomes included symptoms of depression, anxiety, anger, aggression and posttraumatic stress. Perceived social support was measured through inventories of relationships with mothers, fathers, siblings and best friends. The sample consisted of 81 children between the ages of 8-16 and one of their parents. Hierarchical multiple regression analyses found that lifetime trauma exposure and homeless specific complex stress independently accounted for a significant amount of the variance in symptoms of depression, anxiety, aggression, and posttraumatic stress. Lifetime trauma alone accounted for the variance in anger and anxiety related symptomatology. Perceived social support was found to have no influence on mental health morbidity. The study consisted of a novel approach to understanding the psychological experiences of sheltered homeless children. These findings inform the design of clinical interventions for this vulnerable population of children and may have important public policy implications.
\end{abstract}

INDEX WORDS: $\quad$ Homeless children, shelters, trauma exposure, complex stress, Perceived social support. 
TRAUMA EXPOSURE AND BEHAVIORAL OUTCOMES IN SHELTERED

HOMELESS CHILDREN:

THE MODERATING ROLE OF PERCEIVED SOCIAL SUPPORT

by

BERYL ANN COWAN, J.D., M.A.

A Dissertation Submitted in Partial Fulfillment of Requirements for the Degree of

Ph.D.

In the College of Arts and Sciences

Georgia State University 
Copyright by

Beryl Ann Cowan, J.D., M.A 
TRAUMA EXPOSURE AND BEHAVIORAL OUTCOMES IN SHELTERED

HOMELESS CHILDREN:

THE MODERATING ROLE OF PERCEIVED SOCIAL SUPPORT

by

Beryl Ann Cowan, J.D., M.A.

Committee Chairs: Gabriel Kuperminc, Ph.D.

Gregory Jurkovic, Ph.D.

Committee: Lisa Armistead, Ph.D.

Sarah Cook, Ph.D.

Electronic Version Approved:

Office of Graduate Studies College of Arts and Sciences Georgia State University

December 2007 


\section{DEDICATION}

To my parents, Marvin and Lois Cowan, both of whom have led by example.

And to my children, Gabriel and Amara, you have been my light.

And with special thanks to the many families who were brave enough to share their experiences with me, and to the tireless and committed shelter program directors and personnel who facilitated this research, and truly make a difference. 


\section{ACKNOWLEDGEMENTS}

Many people have supported my dream to become a clinical and community psychologist as well as an attorney. Gabriel Kuperminc, Ph.D. has served as my mentor and as my advocate since I returned to graduate training in 1998. In addition to being a wonderful teacher in the classroom, he has trained me to think about research design and has taught me how to write like a social scientist instead of a lawyer writing about social science issues. Gabe has also valued and accommodated my commitment to being a "hands on" mom, and his genuine support of all of my endeavors has made possible my completion of this program.

Gregory Jurkovic, Ph.D. has been a valued mentor as well. Greg has shared his passion for research and clinical work with traumatized children and families with me and other members of his Family Trauma Lab at Georgia State University. I have also benefited greatly from Greg's many gifts as a clinical supervisor, and I will continue to "channel" him in my ongoing clinical work.

Other faculty members who have supported my personal and professional growth over the past years include Katherine Burge-Calloway, Ph.D., Sarah Cook, Ph.D., Martha Foster, Ph.D. and Lisa Armistead, Ph.D.

Several graduate and undergraduate students helped me collect data in shelters: Sam Fasulo, Amanda Lowe, Yara Betancourt, Sandra Yuric, Jocelyn Barton, Angeantte McCall, Chantal Poister, Leon Chafee, Margie Ayati, and Kara Snead. They used their free time to work diligently and under tough conditions. I thank them all for their commitment to my work and the well-being of the children and parents interviewed. I would also like to acknowledge and thank the clinicians who made themselves available to serve as emergency consultants to high risk families: Joanna Ball, 
Claire Rubin, Gerry Goodman, Martha Foster, Susan Kupferberg, Susan Barrett, and Karen Schwartz.

Regina Pyke, Ph.D. has been an inspiring role model as well as an enduring support, and I will always be grateful to her for holding my hand. Finally, I want to thank Myra Carter and Joyce Jackson for loving and caring for my children and for me. Without these two amazing women I would never have had the courage to keep going. 


\section{TABLE OF CONTENTS}

DEDICATION IV iv

ACKNOWLEDGEMENTS $\quad$ v

LIST OF TABLES $\quad$ ix

CHAPTER

1. INTRODUCTION 1

2. UNDERSTANDING THE LANDSCAPE OF HOMELESSNESS 5

3. METHODS 21

4. RESULTS 33

5. DISCUSSION 48

$\begin{array}{ll}\text { REFERENCES } & 62\end{array}$ 


\section{APPENDICES}

$\begin{array}{lll}\text { A Parent Consent Form } & 74\end{array}$

B Parent Interview Form 76

$\begin{array}{lll}\text { C } & \text { PROPS } & 79\end{array}$

D Form to Parent- Warning Signs $\quad 81$

E $\quad$ Youth Assent Form $\quad 82$

F Child Interview Form 83

$\begin{array}{lll}\text { G NRI Short Form } & 84\end{array}$

$\begin{array}{lll}\mathrm{H} & \mathrm{TSCC}-\mathrm{A} & 96\end{array}$

$\begin{array}{llr}\text { I Aggression Form } & 99\end{array}$

J Homeless Experiences Questionnaire Form 100

$\begin{array}{lll}\text { K } & \text { ASTEQ Lite- Parts } 1 \text { and 2 } & 104\end{array}$

$\begin{array}{ll}\text { L Debriefing Form } & 107\end{array}$ 


\section{LIST OF TABLES}

Table 1: 2.1 Criteria for Homelessness (McKinney-Vento Act) 5

Table 2: 4.1 Overall Demographic Characteristics of Adult Participants 34

Table 3: 4.2 Demographic Characteristics of Child Participants 34

Table 4: 4.3 Frequency of Lifetime Traumatic/Stressful Exposures 35

Table 5: 4.4 Overview of Most Frequent Exposures to Traumatic Events 35

Table 6: 4.5 Frequency of Homeless Related Exposures 36

Table 7: 4.6 Overview of Homeless Exposures to Traumatic Events 36

Table 8: 4.7 Scores in Clinical Range for Dependent Variable 38

Table 9: 4.8 Network of Relationships Inventory Results by Relationship Type 38

Table 10: 4.9 Correlations between Independent, Moderating and Dependent Variables 40

Table 11: 4.10 Independent Variables on PROPS 42

Table 12: 4.11 Independent Variables on Aggression 43

Table 13: 4.12 Independent Variables on TSCC-A Posttraumatic Scale 43

Table 14: 4.13 Independent Variables on TSCC-A Depression Scale 44

Table 15: 4.14 Independent Variables on TSCC-A Anxiety Scale 45

Table 16: 4.15 Independent Variables on TSCC-A Anger Scale 46 


\section{Chapter 1}

\section{Introduction}

It is estimated that every year 1.35 million children experience homelessness. Families with children under the age of eighteen constitute $50 \%$ of the homeless population, and are its fastest growing segment (National Alliance to End Homelessness, 2007). It is likely that the exact number of homeless families is higher, as many individuals without their own lodging live temporarily "doubled up" with friends or relatives, or in transient motels, cars, parks and abandoned buildings thus evading census inclusion (National Alliance to End Homelessness, 2007; U.S. Conference of Mayors, 2004; Zima, Wells \& Freeman, 1994). Nonetheless, it is believed that on any given night between 61,000 and 500,000 children are without homes (Children's Defense Fund, 2000; Davey, 2004). Among America's school children, 744,000 are homeless over the course of the school year (Buckner, Bassuk, Weinreb \& Brooks, 1999).

The rise in homelessness nationwide has been associated with declining incomes and an inadequate supply of affordable housing (Burt, \& Laudan, 2000; National Alliance to End Homelessness, 2007; Shinn, et al., 1998). Economically fragile families with limited incomes and facing the increasing costs of food, transportation, clothes, and other necessaries must compete to secure limited stocks of affordable or subsidized housing after paying other bills (National Coalition for the Homeless, 2004; Nuñez, 1994). Forty percent of the people living in poverty are children and homeless youth are undoubtedly among the poorest (Anooshian, 2005; Institute of Children \& Poverty, 2004). While an overarching profile does not exist, homeless families tend to be headed by single women, include young children, and lack strong social networks ( Bassuk, 1993; Bassuk \& Rosenberg, 1990; National Coalition for the Homeless, 2007; 2007; Shinn, et al, 1998). African American families make up the majority of homeless 
families, with Latino families comprising the second most representative ethnic segment of the homeless population (U.S. Conference of Mayors, 2005) As with other impoverished adults, homeless heads of households tend to be poorly educated and under-employed, with limited ability to obtain incomes commensurate with their basic needs (Bassuk, 1993; Friedman, Meschede, \& Hayes, 2003; Hausman, \& Hammen,1993; National Coalition for the Homeless, 2007). Higher incidences of mental health disturbance, debilitating chronic illnesses, substance abuse, domestic violence, unemployment and transience affect the homeless (American Academy of Pediatrics, 2005; Douglas, 1996; Bassuk et al., 1997; Burg, 1994; Rafferty \& Shinn 1991; Weinreb, Buckner, Williams, \& Nicholson, 2006). Families are most likely to become homeless when combinations of factors collide to overwhelm the precarious underpinnings of their everyday existence (Menke, 2000; Muñoz, Vazquez, Bermejo, \& Vazquez, 1999; Shinn, Weitzman, et al., 1998; Shinn, 2002).

The experience of homelessness can be best understood as highly stressful, and, in some instances, traumatic (Anooshian, 2005, Browne, 1993; Goodman, Saxe, \& Harvey, 1991; Muñoz, Vazquez, Bermejo, \& Vazquez, 1999). While homelessness is enormously stressful to individuals of any age, children's experiences are unique in that it involves multiple losses during critical developmental periods (Anooshian, 2005; Zima, Bussing, Bystritsky, Widawski, Belin, \& Benjamin, 1999). Children who are homeless are likely to be forced to leave behind valued possessions, experience disruptions in friendships and other significant relationships, and both change and infrequently attend school (Berck, 1993; Kozol, 1988; Menke, 2000; Stern \& Nuñez, 1999; Yamaguchi, et al., 1997). Additional emotional strains are tied to enduring the social stigma of homelessness (Berck, 1993; Kozol, 1998; Nuñez, 1994; Zima, 1994). 
Living in homeless shelters may be traumatic or at the very least exacerbate pre-existing vulnerability to traumatic exposure (Anooshian, 2005; Berck, 1993; Kozol, 1988; Penuel \& Davey, 1999). Homeless children are often required to spend part of their days alongside their parents negotiating the hierarchical maze of social service agencies that might provide them with a place to sleep (US Conference of Mayors, 2005). When children are sheltered, they must learn and then conform to new rules which dictate what time and under what conditions they eat, sleep, shower, leave and/or return to a building (Friedman, 2000; Kozol, 1988; Penuel \& Davey, 1999). Living in a shelter setting challenges pre-existing family rituals and unbalances the authority of parents creating disharmony for adults and children alike (Anooshian, 2005; Friedman, 2000; Graham-Berman, et al., 1996). Entering shelters may also result in forced separations from parents and siblings due to program restrictions that exclude fathers and/or adolescent boys (U.S. Conference of Mayors, 2005). Shelters crowded with strangers of all ages, some of whom may be emotionally unbalanced or aggressive, may create destabilizing and unsafe environments for children (Anooshian, 2005; Berck, 1992; Friedman, 2000; GrahamBerman, et al., 1996; Kozol, 1988; Nuñez, 1994). Taken individually or cumulatively, the experiences of homelessness are likely to have profound effects on children's social, emotional and cognitive development (Anooshian, 2005; Bassuk, Buckner, et al, 1997; Buckner, Bassuk, Weinreb \& Brooks, 1999; Davey, 2004; Donahue \& Tuber, 1995; Goodman, Saxe, \& Harvey, 1991; Graham-Bermann, Coupet, Egler, Mattis, \& Banyard, 1996; Masten, Miliotis, GrahamBermann, Ramirez, \& Neeman, 1993).

Despite the growing number of homeless children in rural and urban communities, surprisingly little research has assessed empirically the effects of these highly stressful and traumatic experiences on this population (Douglass, 1996). Previous research has focused on 
maladjustment among homeless children without explaining the pathways to such outcomes. The present study was intended to shed light on how exposures to complex trauma and stress, experienced both prior to and in the context of being homeless, affect a population of sheltered homeless children. The types and frequency of lifetime complex trauma exposure which includes maltreatment, loss of significant attachment figures, interpersonal and community violence were investigated. The frequency of homeless related stressors including changes in family functioning, loss of social networks and daily events that were experienced as threatening was also examined. The role played by children's perceptions of social support in the pathway between traumatic exposures and behavioral outcomes was also studied. The implications of this research are many. With better conceptual understanding of the psychological context of homelessness, clinical interventions and program design may be implemented for children and families in need. Moreover, this research may inform policies in ways that ameliorate the long range deleterious effects of homelessness. 


\section{Chapter Two}

\section{Understanding the Landscape of Homelessness}

\section{An Ecological Perspective on Homelessness}

Who are the homeless? Homeless children are those who do not have suitable and/or safe place to live intended for their consistent habitation. The McKinney Vento Act (42 USC 11431), originally enacted in 1984 to provide access to education for homeless children, and later incorporated into Leave No Child Behind Act (2004) has expansive criteria of homelessness, set forth in Table 2.1 below.

\section{Table 2.1}

Criteria for Homelessness (McKinney-Vento Act) ${ }^{1}$

- People doubled up with family and/or friends due to economic conditions

- People living in motels or hotels due to lack of otherwise suitable housing

- Individuals or families living in shelters created for those without homes

- Women and children with homes who are victims of domestic violence

- Children living in transitional housing programs

- Runaway or "throw away" youths

- People living on the street or in abandoned buildings

- People living in public places not intended for housing such as parks, movie theatres, bus stations and campgrounds

- People living in cars

- Children waiting for foster care placement

- Children of migrants living in uninhabitable buildings

\footnotetext{
${ }^{1}$ Access to public education continues to be difficult for many homeless children. Homeless children with special needs have considerable difficulties obtaining appropriate educational opportunities guaranteed to them by law.
} 
Homelessness often occurs when any number of interpersonal and financial factors collide leaving families overwhelmed and without adequate resources to meet daily living needs (Bassuk, et al., 1997; Burt \& Laudan, 2004, National Coalition for the Homeless, 2007; Shinn, Weitzman, et al., 1998). It is not unusual for families experiencing a housing crisis to move from their own homes to those of family members and friends, to move again when overcrowded conditions or interpersonal strife dictates, to seek accommodations in low priced extended stay hotels, or to end up in cars, parks or other public places. In any U.S city, there are more requests for short-term shelter beds or emergency housing than both the public and private sector provide (National Coalition for the Homeless, 2006; U.S. Conference of Mayors, 2005). Waiting lists exist for almost every emergency bed available and for spaces in more long term transitional housing programs (National Law Center on Homelessness and Poverty, 2004). When shelter beds do exist, placement is competitive, and intact families must often disband if an adult male or an adolescent boy seeks admission (U.S. Conference of Mayors, 2004). Many requests for shelter are denied (National Coalition for the Homeless, 2006; U.S. Conference of Mayors, 2005). Homeless shelters rarely exist in rural and suburban areas, forcing some families to travel to larger cities where need already exceeds the demand for shelter (National Law Center on Homelessness and Poverty, 2004). In congregant shelter situations, families are often exposed to persons of all ages, many of whom may be the untreated mentally ill (Friedman, 2000; Kozol, 1989). Children and adults may be subject to overcrowded and noisy conditions at night, and unbending rules and regulations that place them on the street to fend for themselves during the day (Anooshian, 2005; Berck, 1992). The entrance into the morass of "being homeless" exacerbates the already fragile coping mechanisms of poor families, ratcheting up the risk for emotional dysfunction (Anooshian, 2005; Browne, 1993; Davey, 2004; Goodman, Saxe 
\& Harvey, 1991; Graham-Bermann, Ramirez \& Neemann, 1993; Hausman \& Hammen, 1993;

Masten, Miliotis, Graham-Bermannn, Ramirez, \& Neemann, 1993; Menke, 2000; Muñoz, Vazquez, Bermejo, \& Vazquez, 1999; Park, Metraux, Brodbar, \& Cuhane, 2004; Zima, Bussing,et al., 1999; Zima, Wells, \& Freeman, 1994).

\section{The Social Context of Children's Homeless Experiences}

What forces shape the psychological experiences of homeless children? This study investigated homeless children's transactions within their social environments. Of primary focus was the association between parents' and children's reports of traumatic or highly stressful exposures and mental health outcomes. Also explored were children's perceptions of the quality of their relationships with important figures: parents, siblings, and best friends. Each assessment tool utilized in this study tapped into children's perceived transactions with various levels of their ecologies.

Contextualizing the experiences of homeless children from the perspective of an ecological-transactional paradigm is useful. Homeless children, like all children, must be understood within the context of the world in which they live, and the risks and protective factors that they experience. Adjustment and well being, according to the ecological-transactional framework, is the result of interrelated transactions between the individual and the multidimensional ecology that he or she lives in (Bronfenbrenner, 1978, 1979; Livert, \& Hughes, 2002; Lynch \& Cicchetti, 1998; Kuperminc \& Brookmeyer, 2006). An individual's development is molded, in part, through ontogenetic or biological, genetic, neurophysiologic, and intrapsychic processes, and also though continuous transactions with three distinct but interrelated systems: 
the micro-system, the macro-system and the exo-system (Bronfenbrenner, 1978, 1979;

Kuperminc, \& Brookmeyer, 2006; Lynch \& Cicchetti, 1998).

Homelessness is almost always associated with poverty and its entangled sequelae (Bassuk, et al., 1997; Burt \& Laudan, 2000; Friedman, Meschede \& Hayes, 2003; National Coalition for Homelessness, 2007; Shinn, 2002). Through various mechanisms, poverty impacts the developing individual and infiltrates each ecological level, shaping transactions both within and between systems. Even prior to birth, poverty creates risks for unhealthy human development. In utero exposures to illegal substances and alcohol are significantly greater during the pregnancies of poor versus advantaged mothers (Carter, 2002; Hans, 1999). Children born to impoverished mothers often begin life with biological vulnerabilities associated with insufficient or absent prenatal care, inadequate maternal nutrition, low birth weight and/or perinatal complications (National Research Council, Institute of Medicine, 2002; Racine, Joyce \& Grossman, 1999; Reichman \& Teitler, 2003). Poor youngsters are more likely to have chronic, and often untreated medical conditions, as well as cognitive delays (American Academy of Pediatrics, 2005; Singh \& Kogan, 2007).

Children with compromised neurobiological systems may experience emotional dysregulation, attentional deficits, or personality structures that increase vulnerability for maladjustment (Cicchetti, 2002; Kuperminc, \& Brookmeyer, 2006; Leadbeater, Kuperminc, Blatt, \& Hertzog, 1999). These ontogenetic vulnerabilities translate into perceptible stressors that tax the developing child (and his or her family), and leave him or her more susceptible to insults that are encountered at each ecological level. Given lifelong poverty and its impact on ontogenetic processes, many homeless children are especially vulnerable to the stressors attendant in their social environments. 
The micro-system includes, but is not limited to, the family environment (Lynch \& Cicchetti, 1998; Brofenbrenner, 1977, 1979). An extensive literature explores the transactions between individuals and family systems, and the corresponding effect on mental health outcomes among family members. Interactions within family systems are complex at best, and dysfunction may occur regardless of socio-economic class, culture, ethnicity or race. Low income and impoverished families, however, often experience added stressors that compound the difficult path to healthy outcomes (Attar, Guerra, \& Tolan, 1994; Barrera, et al., 2002; Bassuk, 1993;Conger, Ge, Elder, Lorenz \& Simmons, 1994; Graham-Bermann, Coupet, Egler, Mattis, \& Bayard, 1996 ). Various researchers have examined the pathways that link economic instability with behavioral and emotional outcomes in children and adolescents (Barrera, Prelow, et al., 2002; Conger, Ge, Elder, Lorenz, \& Simmons, 1994; Lynch \& Cicchetti, 1998; McLeod \& Shanahan, 1996). Economic instability has been associated with disruptions in parenting, maternal depression and traumatic experiences each of which has been linked to the emergence of childhood emotional and behavioral problems. (Attar, Guerra \& Tolan, 1994; Barrera, Prelow et al., 2002, Conger, Ge, Elder, Lorenz \& Simmons, 1994; Faust \& Katchen, 2004; McLeod \& Shanahan, 1996; Pettit, Bates, \& Dodge, 1997; Vinokur, Price, \& Caplan, 1996). Poor families overall tend to experience greater numbers of significant stressors that impact the developing child (Lynch \& Cicchetti, 1998; McLeod \& Shanahan, 1996; Vinokur, Price \& Kaplan, 1996). When compared with advantaged families, low income families have a higher prevalence of untreated mental illnesses, substance abuse and domestic violence that in turn confound the experiences of many poor children within their homes (Rayburn, Wenzel, Elliott, Hambarsoomians, Marshall \& Tucker, 2005; Johnson \& Glassman, 1990). Chronic illnesses are pervasive in low income families and access to both preventative and primary health care is 
limited (Friedman, Meschede, \& Hayes, 2003; Klerman, 1992). Many poor children have caregivers who are seriously and chronically ill and unable to provide them with appropriate levels of parenting and nurturance (Reyland, McMahon, Higgins-Delessandro \& Luthar, 2002; Rayburn, et al., 2005). Similarly, when a low income child is physically or mentally ill, parents or caregivers may lack the resources, financial and otherwise, to adequately address or remediate the particular needs of their fragile offspring. Stressors associated with poor health or chronic illnesses detrimentally affect each family member and tax the family system as a whole (Reyland, et al., 2002; Behrman, 1992).

Unstable family systems and absentee parents are more prevalent among the poor when compared with more advantaged families (Cummings, Pepler, Moore, 1999; Kilmer, Cowan, \&Wyman, 2001). Low income families experience greater transience and destabilizing life events such as unemployment or job layoffs, frequent moves, interfamily conflict, separation, divorce and premature death (Barerra, et al., 1996; Ickovics, Meade, Kershaw, Milan, Lewis \& Ethier, 2006). Poor families are less likely to enjoy the benefits of strong social support networks that may provide buffers in times of overwhelming stress (Bassuk, 1993; Graham-Bermann, Coupet, Egler, Mattis, \& Bayard, 1996; Maton, 2002). The inadequacy of social support among low income families has been identified as a risk factor for child maltreatment (Anooshian, 2005; Sheidow, Gorman-Smith, Tolan, \& Henry, 2001; Szykula, Mas, Turner, Crowley, \& Sayger, 1991).

In the face of mounting stressors, and inadequate mechanisms of support, family systems may adopt practices that are toxic to healthy child development. Neglect and child abuse are more likely to occur in circumstances of poverty and family adversity (Hausman \& Hammen,1993; Lynch \& Cicchetti, 2002; Pepin \& Banyard, 2006). Researchers have 
underscored the nexus between authoritative and punitive parenting practices, emotional, physical and sexual abuse and emotional disturbance in children (Kliewer, Cunningham, et al, 2004; Cumming, Pepler \& Moore, 1999; Ford, Racusin, Ellis, Davis, Reiser, \& Fleisher, 2000). Early exposure to childhood sexual, physical and emotional abuse has been identified as one of the most significant risks for ongoing traumatic exposures throughout the life cycle (Cook, Spinazzola, Ford, Lanktree, et al., 2005; Nader, 1997; Van der Kolk, Roth, Pelcovitz, Sunday, \& Spinazzola, 2005). While families tend to come in and out of homelessness, most are consistently impoverished. As such, it is expected that many homeless children have experienced events within their family systems that increase their vulnerability to traumatic exposures.

The exo-system consists of the neighborhoods in which families reside. Poor families often live in areas with high rates of unemployment, underemployment and significant levels of neighborhood distress: overcrowded and/or unsuitable housing, abandoned buildings, and high crime rates (Krieger \& Higgins, 2002; Attar, Guerra \& Tolan, 1994). When compared with more advantaged, desirable neighborhoods, low income communities are more likely to be polluted, rat infested and situated near environmental hazards. Children are especially vulnerable to environmental health hazards (Bearer, 2005). Substandard housing has been linked with injuries, chronic disease, including asthma, infectious illnesses, and mental health morbidity (Krieger \& Higgins, 2002; National Council, 2002). Instead of a place of safety and nurturance, extremely poor neighborhoods present many of its inhabitants with adverse conditions which at the very least are daily hassles, and at most, are insurmountable challenges (Attar, Guerra, Tolan, 1994). Low income families are often unable to secure adequate or stable housing resulting in frequent moves and displacement (Shinn, et al., 1998; Friedman, Meschede, \& Hayes, 2003; 
U.S. Conference of Mayors, 2005). Inaccessibility to public transportation limits employment opportunities for residents in many poor neighborhoods. Under-funded school systems are more likely to exist in poor neighborhoods and low income students in need of remedial or special education services are less likely to receive them (Frazier, Cappella \& Atkins, 2007). Untreated learning disabilities contribute to higher than average rates of school failure and truancy thereby perpetuating school drop out, negative peer association and marginal employment (Barrera, Prelow, Dumka, et al., 2002; Yamaguchi, Strawser, \& Higgins, 1997; Zima, Wells, \& Freeman, 1994; Zinkus \& Gottlieb, 1979).

Poor children are at increased risk of exposure to deviant peers and adults engaged in antisocial activities (Self-Brown, LeBlanc, \& Kelly, 2004; Sheidow, Gorman-Smith, Tolan, \& Henry, 2001). Acts of community violence are more prevalent in poor neighborhoods, and children are likely to witness or become victims of aggressive acts (Cicchetti \& Lynch, 1993; Gorman-Smith \& Tolan, 1998; Kliewer, et al., 2004; Lynch \& Cicchetti, 1998, 2002; Sullivan, Kung, \& Farrell, 2004). Exposure to community violence has been associated with emotional and behavioral disturbances in urban and rural youth (Lynch \& Cicchetti, 2002; Overstreet \& Dempsey, 2003; Self-Brown, LeBlanc, \& Kelly, 2004).

The macro-system encompasses the culture and beliefs as well as the social systems that organize the world that children live in (Brofenbrenner, 1978, 1979; Cicchetti \& Lynch, 1998). While an in depth discussion of the macro-system is beyond the scope of the present study, several issues are particularly salient in understanding homelessness. At its core, American society rests on ideals of individualism and self sufficiency. A pervasive ethic of "blaming the poor" for hardship experienced is widely accepted. In the past twenty five years, a conservative political agenda has dismantled many social assistance programs, enacted welfare 
reform and restricted access to other benefits to aid those in need. Poverty rates have risen, affordable low income housing stocks have declined and subsidies or vouchers for existing housing stock have frozen (National Coalition to End Homelessness, 2007). Additionally, urban renewal programs continue to displace low income or impoverished residents without providing alternative housing leaving increasing numbers of families to fend for themselves. Returning veterans from the war in Iraq and people who have lost homes due to the sub-prime mortgage crisis are joining the ranks of the homeless. Many jobs, once available to blue collar and low income labor in this country, are outsourced to grossly underpaid workers in developing nations creating fewer jobs for local unskilled workers. Private and non-profit programs have been unable to meet the demands of families in need of varying degrees of assistance (Burt \& Laudan, 2000; Park, Metraux, Brodbar, \& Cuhane, 2004).

At each level of their social ecologies, homeless children are exposed to potential risk factors that have been associated with poor adjustment at each level of their social ecologies. Protective factors are also inherent in the lives of many homeless children, and many children and families are resilient (Douglass, 1996). Balanced research requires that this population be understood in the context of their social ecologies, with emphasis on strength based and culturally appropriate perspectives.

\section{Using a Trauma Framework to Understand the Effects of Homelessness on Children}

The lifetime poverty experienced by most homeless children places them at increased risk for traumatic exposures (de Vicente, Munoz, Perez-Santos, \& Santos-Olmo, 2004; Ackerman, Newton, McPherson, Jones, \& Dykman, 1998; Bassuk \& Rosenberg, 1990). It is likely that from birth onward, a significant number of the children who ultimately become homeless have been 
exposed to cumulative events of inordinate stress that place them at risk for long range emotional disturbance (Anooshian, 2005; Rayburn, Wenzel, Elliott, Hambarsoomians, Marshall, \& Tucker, 2005; Barber, Fonagy, Simulinas, \& Yates, 1997) Homeless children are more likely than their housed peers to have mothers who have experienced victimization and are suffering from untreated mental health disturbances, particularly depression (Bassuk, et al., 1997; Browne, 1993; Burg, 1994; D’Ercole, \& Struening, 1990; Masten, Miliotis, Graham-Bermann, Ramirez,\& Neeman, 1993; National Coalition for the Homeless, 2007). Moreover, the experience of being homeless may reactivate earlier experiences of trauma for mothers, making them less available to support and or protect their children (Cichhetti \& Lynch, 2002; Browne, 1993). The stressors endured as a result of homelessness may serve to tip the scale for all family members into emotional dysfunction.

Briere \& Spinazzola, 2005;Cook, Spinazzola, et al 2005; van der Kolk \& Courtois, 2005, Van der Kolk, Roth, Pelcovitz, Sunday \& Spinazzola (2005); Briere \& Spinazzola (1995), and others conceptualize the psychological manifestations of posttraumatic stress and/or complex trauma exposures in more expansive terms than those enumerated in the definition of posttraumatic stress disorder contained in the Diagnostic and Statistical Manual IV (American Psychiatric Association, 2004). According to these theorists, complex trauma can occur in the family or home, schools, community or environment and includes events such as maltreatment (neglect, sexual, physical and emotional abuse), interpersonal or community violence, and loss of important caregivers (Cook, Spinazzola, et al, 2005). Many children experience chronic or cumulative trauma. Complex trauma interrupts healthy development, and contributes to maladjustment in seven domains: attachment; biological responses; affect regulation; dissociation; behavior control, cognition and self concept. Symptoms are varied and occur on a 
continuum ( Briere \& Spinazzola, 2005; Van der Kolk \& Courtois, 2005; Van der Kolk, Roth, Pelcovitz, Sunday \& Spinazzola, 2005). Maladjustment is more likely to occur in children whose parent or caregiver invalidates his/her child's posttraumatic reaction, cannot tolerate the child's his/her posttraumatic affect, or cannot manage his or her own reaction to the child's experience of trauma (Cook, et al., 2005). The effects of complex trauma can occur in infancy and persist throughout childhood and adolescence into adulthood (Briere, 1988; Briere \& Spinazzola, 2005; Cook, et al., 2005; Kang, Deren \& Goldstein, 2002; Van der Kolk, et al., 2005).

Children experience symptoms of traumatic exposure differently than adults (Faust \& Katchen, 2004; Ford, et al., 2000; Ickovics, Meade, Kershaw, Milan, Lewis \& Ethier, 2006; Kilpatrick, et al., 2003; Miller, 1999; Pynoos, Steinberg \& Piacentini, 1999). In clinical practice, it is not unusual to observe traumatized children manifesting severe attachment disorders (Cicchetti \& Lynch, 1993), inattention, regressive behaviors (such as encopresis), self mutilation (Glassman,Weierich, Hooley, Deliberto, \& Nock, 2007), and conduct disorders (Ford, et al., 2000; Nader, 1997). Nonetheless, childhood presentations of posttraumatic or complex stress disorders are often overlooked or misdiagnosed. Ackerman, et al. (1998) have reported that traumatized children are often mistakenly identified as having separation disorders, anxiety disorders, oppositional disorders, attention deficit disorder and phobias. Van der Kolk and his colleagues (2005) have noted that when traumatic exposures are recognized they are often viewed as "comorbid" or secondary to other psychopathology, rather than as a complex and multi-symptomatic disturbance in itself. The implications for missing or misunderstanding trauma based psychopathology are critical. First, failure to recognize that a child has been subjected to traumatic abuse or other life threatening events places the child at continued risk for 
ongoing exposures. Second, untreated childhood trauma has been associated with long term psychiatric morbidity including mood disorders, personality disorders, substance abuse, and interpersonal violence both as victim and perpetrator (Moskvina, et al., 2007; Rodriguez, Ryan, van der Kemp, \& Foy, 1997). In the short term, children with untreated or unresolved early trauma tend to function poorly in social and academic settings (Van der Kolk, et al., 2005; Nader, 1997). Early childhood trauma, especially that experienced in the first ten years of life has been associated with greater disturbance than that experienced later (Van der Kolk, 2005, Windom, 1997) Third, unresolved trauma is transmitted across generations: adults with untreated psychopathology are more likely to have children who themselves become victims of childhood trauma. (Lauterbach, Bak, Reiland, Mason, Lute \& Earls, 2007; Van der Kolk et al., 2005; Schumm, Stines, Hobfoll, \& Jackson, 2005; Ackerman, et al., 1998). Untreated posttraumatic stress has been implicated in punitive and remote parenting styles (Lauterbach, et al., 2007). Parents with untreated PTSD are also likely to experience difficulties in establishing social support networks (Anooshian, 2005; Rayburn, Wenzel, Elliott, Hambarsoomians, Marshall \& Tucker, 2005), thereby reinforcing isolation and intensifying stressors for all family members. It is imperative to employ every means necessary to appropriately assess traumatic exposure (Nader, 1997) and to incorporate clinical interventions whenever possible.

This study was designed to investigate the complex trauma exposures of homeless children within their social ecologies. Due to social ecologies of homeless children, the potential for traumatic exposures, as conceptualized by Cook and others was anticipated. Homeless related stress was conceptualized as contributing to psychological maladjustment. Children were envisioned to be the most accurate reporters of the types and frequencies of traumatic events they experienced over the course of their lifetimes, as well as since becoming 
homeless. Children and parents also provided information on their current emotional functioning. This research design was a novel approach to the study of mental health functioning in homeless children.

\section{Perceived Social Support}

Notwithstanding exposure to traumatic events, many children do not suffer deleterious psychological outcomes. Over the past twenty five years, a growing literature has investigated why some individuals appear resilient in the face of adverse circumstances (Luthar, Cicchetti \& Becker, 2000, Masten, 2001). Resilience has been defined as "a dynamic process encompassing positive adaptation within the context of significant adversity" (Luthar, Cicchetti, \& Becker, 2000; Rutter, 1987; Gavazzi, 1994). In efforts to better understand the mechanisms of resilience, researchers have focused on internal resources as well as external events, or factors present in individuals' social ecologies that may serve to moderate the negative outcomes of adverse or traumatic exposures in the developmental pathway (Hoge, Austin \& Pollack, 2007; Jackson, Kim \& Delap, 2007; Hammack, et al 2004; Luthar, Cicchetti, \& Becker, 2000; Gavazzi, 1994; Rutter, 1987).

Studies of resilience begin with empirical evidence of a negative association between specific exposures and psychological outcomes (Douglas, 1996; Gavazzi, 1994; Kilmer, Cowen \& Wyman, 2001; Luthar, Cicchetti \& Becker, 2000). Using multiple regression and other statistical analyses (Holmbeck , 1997, 2002; Baron \& Kenney, 1986) protective factors are investigated to determine the degree to which adverse outcomes are diminished. Kuperminc and Brookmeyer (2006) describe three mechanisms by which protective factors mitigate risk exposure: through actual disruption of the causal pathway between risks and adverse mental 
health; by counteracting direct effects; or by buffering negative effects. Protective factors, like risks, must be understood as transactions within the context of interconnected ecological systems: individual characteristics and vulnerabilities, family systems, and neighborhoods (Kuperminc \& Brookmeyer, 2006; Brooks, 1995; Wills \& Cleary, 1996).

Researchers have investigated the protective role of perceived social support in adults and children exposed to traumatic events (Haden, Scarpa, Jones, \& Ollendick, 2007; Jackson, Kim \& Delap, 2007; Hammack, et al, 2004; Overstreet \& Dempsey, 1999). Perceived social support is not the same as social support; actual social support is best understood as what happens or is likely to happen in the face of adversity, while perceived social support is cognition or an internalized construct about one's relationship with others. Hammack and colleagues (2004) have conceptualized perceived social support as "a general perception of the availability of interpersonal relationships reflected in the daily, social ecology of development". The focus on the protective role of perceived social support is particularly intriguing in light of findings that families at high risk of trauma exposure are likely to have limited social support networks.

In research that shares some of the theoretical underpinnings of the present study, the moderating role of perceived social support in children exposed to community violence has been investigated (Hamack, 2004; Oversetreet \& Dempsy, 1999; Gorman-Smith \& Tolan, 1998). Findings suggest that despite exposure to community violence, some youngsters who perceive that they have or do in fact have relationships that they can turn to for protection, validation, nurturance and comfort, experience less symptoms of internalizing or externalizing disorders (Gorman-Smith \& Tolan, 1998; Hammack, 2004; Overstreet \& Dempsey, 1999). Other researchers have found that strong relationships with significant others, most importantly parents, best friends and more recently siblings, diminishes the degree of posttraumatic 
symptomatology (Hoge, Austin, \& Pollack, 2007). The relative importance of supportive relationships with parents as compared with best friends over the course of childhood has been a particular focus of research interest.

To date, there is no existing research on the protective role of perceived social support on homeless children who have been exposed to significant stress or trauma. Understanding the moderating role of perceived social support is critical to understanding the pathways between traumatic exposure and mental health outcomes in this extremely vulnerable population of children. Investigating children's perceptions of social support from parents, siblings, and best friends independently and in combination may clarify why some homeless children fare better emotionally than others. An understanding of perceived social support in the context of homelessness may inform clinical interventions and programmatic design.

\section{Goals of the Present Study}

This study was designed to study the association between trauma exposures and mental health outcomes. The moderating role of perceived social support, in this pathway was also investigated. The following research questions guided this study:

1. To what extent have homeless children been exposed to potentially traumatic events and does the frequency of these exposures contribute to variance in symptoms of aggression, depression, anxiety, anger and posttraumatic stress? It was hypothesized that homeless children would have cumulative exposures to lifetime trauma and that such exposures would account for statistically significant amounts of variance in these psychological outcomes.

2. Once homeless to what extent do children experience highly stressful events, and does 
the frequency of such events independently contribute to statistically significant variance in symptoms of anger, aggression, depression, anxiety, anger and posttraumatic stress? It was hypothesized that the frequency of contextual homeless related stress would contribute to significantly significant variance in these symptoms over and above that attributed to lifetime trauma exposure, age and gender.

3. Lifetime exposure to trauma and homeless related stress will contribute independently to explained variance in symptoms of aggression, anxiety, depression, anger and posttraumatic stress in homeless children.

4. Perceived social support from mothers, fathers, siblings and best friends will moderate the psychological effects of lifetime traumatic exposures and homeless related trauma on symptoms of aggression, anxiety, depression, anger and posttraumatic stress in homeless children. 


\section{Chapter Three}

\section{Methods}

\section{Participants}

Eighty- one children between the ages of 8-16 and one of their respective parents or parental figures participated in the current study. Of the adult participants, only two were males. ${ }^{2}$ Participants were interviewed between May 2006 and July 2007.

Sixty-two percent $(n=81)$ of the child participants were female. The children ranged in ages from eight to sixteen with fifty- eight percent of the children between the ages of eight through eleven, and forty-two percent between the ages of twelve and sixteen. The mean age of the child participants was $11.11(\mathrm{SD}=2.4)$.

The adult participants ranged in ages from 26 through 53. Seventy-six percent $(n=81)$ of the adults were ages forty or younger. The median age of the parents was 34.5 years old and the mean age was 36.2. A significant majority of the parents were single heads of households with $47 \%$ reporting their marital status as single; $21 \%$ stating they were separated and $18.5 \%$ indicating that they were divorced.

At the time of data collection, a majority of the participants were residing at one of twelve shelter or transitional housing locations in the metropolitan areas of two large American cities. Eighty-five percent $(n=81)$ were interviewed at programs within the metropolitan area of a southern city, whereas fifteen percent were located at programs in a northeastern city. The majority of participants were African American $(74 \%, n=81)$. The participants in the northeastern city included Cape Verdians, Latinos as well as African American and white participants, and thus were more racially and ethnically diverse than the southern sample.

\footnotetext{
${ }^{2}$ Given the predominance of female participants in the adult sample, all parents will be referred to as mothers.
} 


\section{Procedures}

The procedures were approved by the Institutional Review Board at the investigator's academic institution. Initial contacts were made with program directors of licensed homeless shelters and/or transitional programs, and the purpose and methodology of the study were explained. None of the programs contacted were exclusively serving victims of domestic violence. By having already been pre-identified as witnesses or victims of domestic violence, it was determined that residents of programs exclusively serving battered women and their children would bias the randomness of the sample. Adults who became homeless in the wake of Hurricanes Rita and Katrina were excluded from the study. Again, it was determined that the traumatic nature of experiencing a natural disaster and relocating in its aftermath might skew the results of the study.

Group information sessions were scheduled to explain the purpose of the study to potentially eligible adult program residents. Eligibility was determined on the basis of having at least one child between the ages of eight through sixteen. After providing general information about the study, interested adult participants were invited to meet individually with trained research staff. Following further discussion of the risks and benefits, as well as the parameters and limits of confidentiality, adult participants gave written consent for their own inclusion and that of their child. Where a parent participant had more than one child who met criteria for inclusion in the study, random selection was made. Written assent was obtained from each child participant after he or she was explained the risks, benefits and limits of confidentiality in age appropriate terms. 
Upon obtaining written parental consent and child assent, a trained researcher met separately with parent and child participants in a designated private office or conference room within each shelter location. Parent interviews took approximately thirty minutes, while sessions with children lasted one hour on average. Parents were given ten-dollar gift certificates. Children were allowed to select age appropriate prizes for themselves as well as a prize for each of their siblings.

All researchers were trained extensively in the assessment of parents and children in shelter and transitional housing settings. Where a family had more than one child who met the age criteria for inclusion in the study, a random selection was made, usually through a coin flip. Data collection was conducted in one to one sessions, with the same investigator interviewing both the parent and randomly selected child. The child and the parent were interviewed separately. When administering the data collection measures, the investigator read each question aloud. All questions were written in language that was easy to understand and culturally sensitive. No difficulties understanding the measures were observed in any of the participants.

\section{Measures}

\section{Dependent Variables}

Parent Report of Posttraumatic Symptoms (PROPS, Greenwald \& Rubin, 1996)

The PROPS is a 32 item parent report measure of a child's posttraumatic symptoms during a one week period. The measure is intended for use in clinical and/or research settings with parents of children with or without known traumatic exposure, ages eight through fifteen (Greenwald \& Rubin, 2002). Parents report the prevalence of symptoms using a three point Likert Scale $(0=$ Not True or Rarely True, $1=$ Somewhat True or Sometimes True, $2=$ Very True or Often True). Questions are such as: "difficulty concentrating", "thinks of bad memories", and 
"startles easily" capture symptoms of posttraumatic stress. Higher scores are associated with greater likelihood of posttraumatic distress. A score of 16 or greater is used as a clinical cutoff score indicating greater than average distress. Noting that parents tend to be more reliable in reporting their child's behaviors versus their internal states (Loeber, Green, \& Lahey, 1990), the authors intended the PROPS to be used alone or in conjunction with other reports of trauma related symptomatology (Greenwald \& Rubin, 1999). The behaviors measured through the PROPS correspond to the more expansive conceptualization of trauma or complex stress experienced by children (Briere \& Spinazzola, 2005; Cook, et al., 2005; Van der Kolk \& Courtois, 2005) and is not restricted to symptomatic manifestations of PTSD as defined in the DSM-IV (Greenwood \& Rubin, 1999; DSM-IV, 1994).

In five separate studies the PROPS has been shown to have sound psychometric properties with high levels of internal consistency $($ alpha $=.93)$, test-retest reliability $(r=.79)$ and criterion validity $(r=.56)$ as indicated by prior exposure to trauma (Greenwald, Rubin, Jurkovic, Wiedemann, et al., 2002). The measure has been validated on samples of urban and rural youth in the United States, many of whom were ethnic minorities, and on select populations of children in several European countries. In the present study, the internal consistency estimate was alpha $=.92$.

Trauma Symptom Checklist for Children-A (TSCC-A, Briere, 1996)

The Trauma Symptom Checklist for Children-A (TSCC-A) is a 44 item self report measure used to assess symptoms of posttraumatic and complex stress disorders in children 8-16. The measure is designed to identify clinical presentations of children exposed to complex stress and trauma and is not limited to assessment of posttraumatic stress disorder as outlined in the 
DSM-IV (Briere \& Spinazzola, 2005). Utilizing a 4 point Likert Scale $(0=$ never, $1=$ sometimes, $2=$ lots of times, $3=$ almost all of the time) respondents endorse how often they experience specific feelings, thoughts or behaviors. Examples of questions include "Feeling scared of men/women"; "Pretending I am somewhere else", "Getting scared all of a sudden and don't know why". The measure is written at an eight year old reading level. The TSCC-A contains no questions that are related to sexual concerns. This measure was included in this study because it provides complementary information regarding internal feeling states and experiences not available through the other dependent variable measures.

The TSCC-A contains 2 validity scales (Under-reporting and Over-reporting) as well as 5 clinical subscales: Anxiety, Depression, Aggression, Posttraumatic Stress, and Disassociation. Raw scores are converted to $\mathrm{T}$ scores with a clinical cutoff point at 65 indicating above average levels of emotional distress. Normative data for the measure were obtained from 3000 inner city, urban and suburban children. The measure has been found to be internally consistent with alpha coefficients for clinical scales ranging from .77-89 in the standardization sample. Reasonable convergent, discriminant and predictive validity has also been shown in both normative and clinical samples (Brierre, 1996; Sadowski \& Friedrich, 2000).

In this study, the TSCC-A measure was administered orally due to its length and the hypothesized range of reading abilities among the sample of youths. Raw scores and $\mathrm{T}$ scores were tallied. The internal consistency of responses to the overall measure was high with a Cronbach alpha of .94. Internal consistency of the subscales are reported with the following Cronbach alphas: anxiety .82; depression .86 ; anger .89 and posttraumatic stress .87 . 
Aggression Scale (Orpinas \& Frankowski, 1993)

The Aggression Scale (Orpinas \& Frankowski, 1993) is an eleven item self report measure of the frequency of aggressive acts. The measure was designed to assess the prevalence of common types of overt aggressive behaviors in middle school students. Using a Likert Scale, respondents are required to identify how many times ( ranging from 0 to $6+$ times) in a given one week period they have engaged in specific aggressive acts including physical actions (hitting, slapping, pushing) and verbal behaviors (teasing others, calling others bad names, or threatening to hurt someone else). Respondents are also required to specify how many times during the same period they experienced anger or were motivated by anger.

The psychometric properties of the Aggression Scale have been established in three studies with an ethnically and socio-economically diverse population of sixth graders (Orpinas \& Frankowski, 2001). Internal consistency was high, with a Cronbach alpha coefficient of .87. Test-restest reliability was also high and did not vary significantly across gender, ethnicity or grade level. Construct and predictive validity was also strong when measured against independent ratings of behaviors (including teacher reports) and other predictors of violent behaviors (Orpinas \& Frankowski, 2001; Orpinas, Parcel, McAlister, \& Frankowski, 1995). In the present study, children were asked to report the number of times over the past week that they had engaged in each of the eleven behaviors. Participants were assured that there would be no negative consequences resulting from their truthful reports. The number of times an act occurred was entered, and an over all score ranging from 0-60+ was tallied. Internal consistency was high with a Cronbach alpha of .914. 


\section{Independent Variables}

\section{Parent Interview}

Demographic information concerning the parent's age, marital status, and numbers of children were collected. Also obtained was information related to the present experience of homelessness including precipitant events, lengths of stays in shelters, and number of schools that their child had attended in the past year. Parents were also asked to enumerate past experiences of homelessness. Finally, each parent was asked whether their child's behavior had changed during the recent period of homelessness.

Adolescent Stress and Exposure Questionnaire-Brief Version (ASTEQ- Lite, Cowan, Jurkovic \& Kuperminc, 2005)

The ASTEQ -Lite (Cowan, Kuperminc, \& Jurkovic, 2005) is a new measure that has been developed to assess lifetime exposures to a range of potentially stressful and/or traumatic events. Modeled on the ASTEQ-2 (Jurkovic et al.,2006) and its prior version, the Youth Trauma and Stress Screening Inventory (Ball, et al, 2006; Fasulo, 2007) the ASTEQ- Lite is intended to assess stressful or traumatic exposures in a wider age range of children by including school aged youth as well as adolescents. The ASTEQ-Lite differs also from the two other measures in that it is comprised of fewer questions (45 questions versus 63 questions).

As with the ASTEQ-2, the ASTEQ-Lite assesses possible lifetime exposures to events of interpersonal and domestic violence, community violence, neglect, natural disasters and loss. As with the prior two iterations, the ASTEQ-Lite questions were designed following the careful review of the existing literature of complex trauma in high risk families and children, and the input of clinicians and researchers working with this population. The ASTEQ-Lite questions are 
worded to be easily understandable by school aged children. Moreover, the ASTEQ-Lite contains five questions that are intended to be excluded when the measure is administered to children eleven and younger. These excluded questions are considered inappropriate for younger children due to their sexual related content (Have you ever been pregnant or gotten someone pregnant? Have you ever had a really bad break up with a boyfriend or girlfriend? Have you ever had an abortion or helped someone have an abortion?) or inclusion of experiences unlikely to have occurred prior to attaining early adolescence (Have you every had to take a job to help support your family? Have you ever had a bad experience when using drugs and alcohol?).

Due to the almost identical formats of the ASTEQ-Lite with the prior iterations, it is expected that all three share psychometric properties. Predictive validity of the original YTSSI measure was established in a study of incarcerated juvenile offenders with various psychosocial outcomes (See Ball et al., 2006 for further discussion). Utilizing confirmatory factor analysis results, a second study (Fasulo, 2007) supported the predictive validity of the ASTEQ-2 when measuring emotional distress and trauma related symptoms in incarcerated youth (Fasulo, 2007). However, it is noted that the use of the ASTEQ-Lite in the present study breaks new ground in two important respects: first, in its application to a population of school aged children as well as adolescents, and second, in its administration to youths not currently detained in juvenile justice facilities.

The ASTEQ-Lite was administered to the child participants as a card sorting task. Respondents made separate piles of events that happened to them, or "yes piles" and events that did not happen, or "no piles". Examples of questions: "Has your mom or dad ever been arrested and put in jail"; "Have you seen your parent punch, fight or hit another grown up", "Have you ever been around a shooting, drug bust or gang fight"; "Has someone that you really loved died" 
track events of loss, interpersonal and community violence exposure, and deviant peer association. . Positive responses were tallied, with greater numbers of "yes" cards signifying more exposure to chronic or discreet events of trauma or significant stress. Internal consistency was high with a Cronbach alpha of .83 .

Homeless Experiences Questionnaire for Children (Cowan, Kuperminc \& Jurkovic, 2005)

The Homeless Experiences Questionnaire for Children (HEQC) is a new measure specifically designed to assess stressful exposure within the context of homelessness. This measure is novel in that until now there has been no known psychometric tool that empirically documents both the frequency of such experiences and how children feel about them. The importance of creating such a measure, as well as its contents and design were informed after an extensive multidisciplinary review of the social science literatures on homeless children, narratives published by homeless or formerly homeless children, and interviews with advocates and personnel working in programs that serve homeless families .

The HEQC encompass five interrelated thematic stressors that are endemic in the experiences of homeless children: the loss of important attachments (possessions, pets, friends and family members); the disruption of a sense of place and belonging (schools and peer groups); the displacement of previous family hierarchies, rituals and autonomy; and experiences of personal vulnerability and stigma. The two part format of the measure allows children to identify through a card sorting task whether any of 18 separate experiences pertained to them. Yes and no piles are established, and the frequencies of events were tallied. Questions are tied to common homeless related stressors: 'Did you lose important toys and stuff?”, "Have you missed 
a lot of school?", "Have other people at your shelter said or done something to you that was threatening or scary to you?". Then using a 4 point Likert Scale, (1=Not Hard at All, 2=A Little Hard, 3= Medium Hard, 4=Very Hard) child participants were asked to rate how hard each positively endorsed experience was (i.e. If you had to learn a lot of new rules at your shelter, how hard has that been for you?) The responses to each positively endorsed question were tallied. Only Part 1 of the HEQC was used in this study. The Cronbach alpha for Part 1 of the HEQC was .76.

\section{Moderating Variables}

Perception of Social Support (Furman \& Burhmester, 1992)

The Network of Relationship Inventory (short form) was used to measure each child's perception of social support from four different relationships: mother, father, sibling and best friend. This 7 item measure assesses a child's perception of the stability of each relationship, and the functions of each relationship. Examples of question included : "How much does your mom really care about you?"; "How much does your mom help you figure out and fix things?", "How much do you share your secrets and private feelings with your mom?". Each inventory is exactly the same, and overall children responded to 28 questions about their relationships with significant others.

In this sample, coefficient alphas representing the internal reliability of the subscales fell between .51 and $.82 .($ father $=.82$, mother $=.73$, sibling $=.73$, best friend $=.51$ ) Each scale was considered a separate moderating variable in the present study. 


\section{Analyses}

The initial data analyses involved descriptive statistics. Demographic information pertaining to the sample (age, gender, race, ethnicity, marital status, duration of homelessness) was analyzed. Additionally, frequencies and types of lifetime and homeless stressful exposures were calculated. The second stage in the analysis encompassed analyses of the association between trauma exposure and mental health outcomes using hierarchical multiple regression. Dependent variables were parent reported observations of children's posttraumatic symptoms (PROPS), and child reported symptoms of aggression (Aggression Scale) anxiety (TSCC-A Anxiety subscale) depression (TSCC-A Depression subscale) posttraumatic stress (TSCC-A Posttraumatic Stress subscale) and anger (TSCC-A, Anger subscale). Separate regression models were estimated for each dependent variable. After controlling for age and gender in the first step of each regression equation, lifetime exposure to stressful or traumatic events was entered in the second step. Next, stressful events tied specifically to the experience of homelessness were entered in the third step.

The next stage in data analyses entailed examining social support as a moderating variable in the relationship between trauma exposures and mental health outcomes. Each of four significant relationships (mother, father, sibling and best friend) was investigated separately as a moderator of the associations between lifetime exposure to stress/trauma, and contextual homeless stress. Multiple regression was used to establish the significance of these moderating variables. In order to create the interaction terms, each variable (ASTEQ-lite, HEQC, NRI-Mom, NRI-Dad, NRIsibling, and NRI-bestfriend was centered by subtracting each variable's mean from each score resulting in a new centered mean. Interaction terms were created by multiplying 
the centered ASTEQ score with each centered NRI score (ASTEQcxNRIc-mom, dad, sibling, friend) and by multiplying the centered HEQC score (ASTEQcx NRIc-mom,dad, sibling,best friend). Two separate sets of moderation analyses were run. The first group of analyses involved examining the effect of perceived social support on the relationship between lifetime trauma exposure and mental health outcomes. After controlling for age and gender in the first step of the regression analyses, the centered ASTEQ score was entered into the model as step two. The centered support variable (c-nrimom, c-nridad, c-nrisib, and c-nribf, respectively) was entered as step three. The interaction term was entered as step four (ASTEQcxNRIc). This model was run on each of the six dependent variables (PROPS, Aggression Scale, TSCC-A subscales, depression, anxiety, posttraumatic stress, and anger). The second set of moderation analyses followed the same model, replacing the centered HEQC variable and the HECQx NRI interaction terms in each of the sequential steps. In all, 48 moderation analyses were run. 


\section{Chapter Four}

\section{Results}

\section{Preliminary Analyses}

\section{Data Management}

The data were inspected for skewness, outliers, and missing variables. Less than 5 percent of cases contained missing data. Data were found to be missing completely at random (MCAR) with a non-significant value for Little's $\mathrm{MCAR},(\mathrm{df}=2,1.310) p=.52$. Thus, missing data were imputed using the expectancy maximization algorithm (Tabachnick \& Fidell, 2001). Frequencies and standard deviations were calculated for each of the independent, and dependent, and moderation variables. As previously explained, the independent and moderating variables were centered to create interaction terms.

\section{Demographic Information}

All participants were homeless in accordance with the criteria set forth in the McKinney Vento Act (42 USC 11431). Participants were residing in one of twelve shelter programs located in two major metropolitan areas. Over a past one year period, the mean length of shelter stays for participants was 23.4 weeks. A majority of mothers $(54.3 \%)$ reported previous homeless experiences. Sixty five percent of the participants lived in more than two places over the past year, with the average family living in 3.3 places. Sixty five percent of children attended two or more schools over the past year.

Seventy-seven of the 81 adult participants were female heads of households, ranging in ages from 26 to 53 . The mean age of adult participants was 36.15 and the median age was 34.5 years $(\mathrm{SD}=6.4)$. Information on adult participant demographics is found in Table 4.1. 
Table 4.1

Demographic Characteristics of Adult Participants

\begin{tabular}{lcc}
\hline Variable & Frequency Percentage \\
\hline Parent Age (years) & & \\
$26-30$ & 15 & 18.5 \\
$31-35$ & 31 & 38.3 \\
$36-40$ & 15 & 18.5 \\
$41-45$ & 12 & 14.8 \\
$46-53$ & 7 & 8.6 \\
Race & & \\
African-American & 59 & 73.8 \\
Caucasian/ White & 8 & 10.0 \\
Latino & 5 & 6.3 \\
Bi-racial & 2 & 2.5 \\
Other & 6 & 7.4 \\
\hline
\end{tabular}

Forty-nine percent of the adults reported that they had children who were not living with them at the present time. A majority of the children not living with their parents were reported to be staying with friends or relatives, and fewer were in foster care. The predominant reason given for parent-child separations was the age of the child (adolescents or adult children).

A majority of the children were between eight and eleven years old (58\%), with $42 \%$ between the ages of 12-16. The children were overwhelmingly African American (73\%). Table 4.2 displays the demographic information for all child participants.

Table 4.2

Demographic Characteristics of Child Participants

\begin{tabular}{lcc}
\hline Variable & Frequency & Percentage \\
\hline Child Age (years) & 47 & \\
$8-11$ & 34 & 58.0 \\
$12-16$ & & 42.0 \\
Race & 59 & 73.8 \\
African-American & 8 & 10.0 \\
Caucasian/ White & 5 & 6.3 \\
Latino & 2 & 2.5 \\
Bi-racial & 6 & 7.4 \\
Other & & \\
Gender & 50 & 61.7 \\
Female & 31 & 38.3 \\
Male & & \\
\hline
\end{tabular}


The northeastern group of children were more racially and ethnically diverse than the southern sample.

\section{Descriptive Statistics-Independent Variables}

Using the ASTEQ-Lite (Cowan,et al., 2005), child participants were asked to positively identify lifetime exposure to specific stressful or traumatic events. The total number of events endorsed by each child was summed to create a total score. The mean exposure to stressful or traumatic events was 11.21 events $(\mathrm{SD}=5.63)$. Table 4.3 shows the frequency of lifetime traumatic/stressful events reported by the youth participants. Table 4.4 includes the relative percentages of highly stressful lifetime experiences reported by children.

\section{Table 4.3}

Frequency of Lifetime Traumatic/Stressful Exposures

\begin{tabular}{lll}
\hline Number of Exposures & Frequency & Percent \\
\hline $2-6$ & 17 & 20.9 \\
$7-11$ & 25 & 30.7 \\
$12-17$ & 30 & 37.1 \\
$18-22$ & 5 & 6.1 \\
$23-28$ & 4 & 4.9 \\
\hline
\end{tabular}

\section{Table 4.4}

Most Frequent Traumatic Events Reported

\begin{tabular}{ll}
\hline Item & Percentage \\
\hline Death of parent or family member that child really loved & 72 \\
Lots of yelling, arguing, cursing at home & 63 \\
Child heard gunshots in neighborhood & 63 \\
Child was really sick and needed to go to the hospital & 56 \\
Child witnessed fights between non-family members & 55 \\
Parent became sick and couldn't care for the child & 52 \\
Mother or father arrested and/or jailed & 48 \\
Child stayed back in school & 34 \\
Child helped break up a fight between parents or family members & 33 \\
Parents called child names or put child down & 29 \\
Child witnessed parents hurting each other & 28 \\
\hline
\end{tabular}


From the data collected, it is apparent that this population of homeless children experienced significant events of interpersonal violence; family discord and disruption; community violence; physical, emotional and sexual abuse; neglect; and, loss of significant attachments with caregivers.

Through the HEQC (Cowan, et al, 2005) children were asked to endorse stressors experienced specifically within the context of homelessness. The total numbers of positively endorsed items, ranging from 0-18 were summed to create a total score. The overall frequencies of scores are included below in Table 4.5. The frequencies of stressful homeless events are shown in Table 4.6.

Table 4.5

Frequency of Homeless Related Exposures

\begin{tabular}{lll}
\hline Number of Exposures & Frequency & Percent \\
\hline 0 & 1 & 1.2 \\
$1-5$ & 24 & 29.6 \\
$6-10$ & 40 & 49.2 \\
$11-18$ & 16 & 19.8 \\
\hline
\end{tabular}

The frequencies of stressful homeless exposures are contained in Table 4.6 below.

\section{Table 4.6}

Reported Homeless Exposure to Traumatic Events

\begin{tabular}{ll}
\hline Item Reported & Percentage \\
\hline Had to learn new rules at shelter & 80 \\
Stopped seeing special friends & 72 \\
Changed schools & 69 \\
Had to help mom in new ways since becoming homeless & 67 \\
Loss of important toys and possessions & 58 \\
Missed a lot of school & 47 \\
Friends not allowed to visit at shelter & 44 \\
Stopped seeing aunts, cousins, grandparents & 42 \\
Mom behaved differently since becoming homeless & 36 \\
Teased by peers & 33 \\
Feels unsafe at shelter & 22 \\
Bullied by peers & 21 \\
Separated from family members not allowed to stay at shelter & 20 \\
Feels threatened at shelter & 11 \\
\hline
\end{tabular}


As is evident, these children experienced shelter mandated family separations, the interruption of important connections with family and friends, and the disruption of school placement and attendance.

\section{Descriptive Statistics-Dependent Variables}

The mean score on the mother-reported PROPS was $17(\mathrm{SD}=12)$. Utilizing a clinical cut off score of 16 (Greenwald, Rubin, Jurkovic et al, 2002), 43\% of the children were found to be manifesting clinically significant levels of symptoms associated with exposures to traumatic or highly stressful events.

The child-reported TSCC-A contains 5 clinical subscales of which four: anxiety, depression, anger and posttraumatic stress are reported in this study. Using scales normed on populations of at risk, ethnically diverse youth (Briere, 1996) the TSCC-A raw scores were converted to $T$ scores. $T$ scores above 65 are reported below for each of the four clinical subscales.

Using the Aggression Scale, children reported the frequencies of aggressive acts or moods during a one week period. Aggression Scale scores ranged from 0- 62. The mean score on the Total Aggression Scale was 19 with a standard deviation of 17 . In the absence of normed scores to reflect clinical range, scores above the sample mean were reported.

Table 4.7 below contains the frequencies of scores in the clinical ranges for each of the dependent variables. 
Table 4.7

Scores in Clinical Range for Dependent Variable

\begin{tabular}{lll}
\hline Dependent Variable Measure & Frequency & Percent \\
\hline PROPS & 35 & 43 \\
TSC-Anxiety & 14 & 17 \\
TSC-Depression & 12 & 15 \\
TSC-Anger & 10 & 12 \\
TSC- PTSD & 11 & 14 \\
Aggression Scale & 32 & 40 \\
\hline
\end{tabular}

Children rated their relationships with mothers, fathers, siblings and best friends. Each relationship inventory was scored separately. The frequencies, means, and standard deviations for each of the four relationships measured are contained in Table 4.8 below.

Table 4.8

Network of Relationships Inventory Results by Relationship Type

\begin{tabular}{llll}
\hline & Frequency & Mean & Standard Deviation \\
\hline Mothers & 79 & 27 & 4.8 \\
Fathers & 44 & 23.2 & 4.8 \\
Siblings & 67 & 25 & 5.3 \\
Best Friends & 71 & 26 & 6.4 \\
\hline
\end{tabular}

Sixty seven children provided information about their relationships with siblings. Fifty two percent provided information about perceived social support from sisters, $48 \%$ responded about brothers. Seventy one children reported on the quality of their relationships with best friends. Ten children reported that they did not have a best friend. Forty six of the best friends were identified as girls while twenty five were boys.

\section{Correlations between Independent, Moderating and Dependent Variables}

Correlations between the independent, dependant and moderating variables were analyzed in Table 4.9. There was no significant correlations between age, gender and any of 
other independent, dependent or moderating variables. Correlations between the four TSCC-A subscales and the Aggression Scale were significant. The PROPS did not correlate significantly with any of the other dependent variables. While all dependent variables correlated significantly with the independent variables, the relationships between the PROPS and the ASTEQ and HEQC were the weakest. Anger symptoms and parent observed posttraumatic stress symptoms were negatively correlated with perceived social support from best friends. Aggression symptoms were positively correlated with perceived social support from fathers. Perceived support from mothers and fathers were significantly correlated. No other correlations between the moderating and other variables were statistically significant. 
Table 4.9

Correlations between Independent, Moderating and Dependent Variables

\begin{tabular}{|c|c|c|c|c|c|c|c|c|c|c|c|c|}
\hline Variable & 1 & 2 & 3 & 4 & 5 & 6 & 7 & 8 & 9 & 10 & 11 & 12 \\
\hline 1. TSCC Anxiety & - & $.66^{* *}$ & $.34 * *$ & $.87 * *$ & 0.19 & $.40 * *$ & $.33 * *$ & $.35 * *$ & 0.01 & -0.04 & 0.02 & -0.16 \\
\hline 2. TSCC Depression & & -- & $.52 * *$ & $.70 * *$ & 0.15 & $.54 * *$ & $.37 * *$ & $.43 * *$ & -0.09 & -0.09 & 0.17 & 0.08 \\
\hline 3. TSCC Anger & & & -- & $.44 * *$ & 0.02 & $.52 * *$ & $38 * *$ & 0.13 & 0.11 & 0.15 & -0.03 & $-.26^{*}$ \\
\hline 4. TSCC PTSD & & & & -- & 0.17 & $.45 * *$ & $.42 * *$ & $.48 * *$ & -0.04 & -0.002 & 0.03 & -0.2 \\
\hline 5. PROP Score & & & & & -- & 0.13 & $.25 *$ & $.31 * *$ & -0.02 & 0.13 & 0.06 & $-.24 *$ \\
\hline 6. Aggression & & & & & & -- & $.62 * *$ & $.42 * *$ & 0.18 & $.24^{*}$ & 0.08 & -0.11 \\
\hline 7. ASTEQ & & & & & & & -- & $.42 * *$ & 0.05 & 0.04 & 0.15 & -0.18 \\
\hline 8. HEQC & & & & & & & & -- & 0.04 & 0.13 & 0.09 & -0.07 \\
\hline 9. NRI Mom & & & & & & & & & 1 & $.24^{*}$ & 0.14 & -0.05 \\
\hline 10. NRI Dad & & & & & & & & & & 1 & 0.12 & 0.14 \\
\hline 11. NRI Sibling & & & & & & & & & & & 1 & 0.16 \\
\hline 12. NRI Best Friend & & & & & & & & & & & & 1 \\
\hline
\end{tabular}




\section{Correlations between Independent, Moderating and Dependent Variables}

\section{Hypothesis Testing}

The first two hypotheses entailed the relative contributions of exposures to lifetime traumatic events and homeless specific stressful experiences on mental health outcomes. First it was predicted that lifetime exposures to trauma accounts for significant amounts of the variance in children's mental health functioning as reported by parents (PROPS), children's self reports of aggressive acts and feelings (Aggression Scale), and children's experiences of anxiety, depression, anger and posttraumatic stress (TSCC-A). Second, it was expected that the highly stressful or traumatic experiences that children encounter as a result of their homelessness contributes to significant amounts of variance in the same mental health outcomes separate and apart from lifetime traumatic exposures. A third hypothesis postulated lifetime trauma and homeless related trauma or stress would be independently associated with emotional disturbance. Statistical support was found for each of these three hypotheses. A fourth hypothesis predicted that children's perceptions of support from mothers, fathers, siblings and best friends would alter the pathway between traumatic exposures and mental health outcomes. This hypothesis was not supported.

Regression Analysis of the Independent Variables on PROPS Scores

The contribution of lifetime trauma exposure and homeless related events on parent reports of PTS symptomatology was analyzed through multiple regressions. Table 4.10 reports the findings below. 
Table 4.10

Independent Variables on PROPS

\begin{tabular}{llll}
\hline & $\mathrm{B}$ & $\mathrm{R}^{2}$ & $\Delta \mathrm{R}^{2}$ \\
\hline $\begin{array}{l}\text { 1. Gender } \\
\text { Age }\end{array}$ & -.009 & .005 & .005 \\
Step One & .70 & & \\
2. ASTEQ-EM & $.266^{*}$ & .066 & $.062^{*}$ \\
$\quad \begin{array}{l}\text { Step Two } \\
\text { 3. HEQC-EM }\end{array}$ & $.257^{*}$ & $.118^{*}$ & $.052^{*}$ \\
$\begin{array}{l}\text { Step Three } \\
\text { *p }<.05 * * \mathrm{p}<.01{ }^{* * *} \mathrm{p}<.001 \mathrm{n}=81\end{array}$ & & \\
Model Summary $\mathrm{F}(4,76)=2.554 \mathrm{p}<.05$ & &
\end{tabular}

Traumatic stress and homeless stress exposure each contributed independently to explained variance in parents' reports of posttraumatic stress symptoms (6\% and 5\% respectively, $\mathrm{p}<.05$ ). The numbers of lifetime trauma experienced were strongly associated with the posttraumatic behaviors observed by parents. The stressors experienced in the context of being homeless contributed to parent observed symptomatology above and beyond the contributions of age, gender and lifetime trauma exposures.

Regression Analysis of Independent Variables on Aggression Scale

After controlling for age and gender, the independent contributions of lifetime trauma and homeless related stress on aggressive behaviors were significant. Traumatic lifetime exposures had a strong main effect accounting for $33.3 \%$ of the variance in children's aggressive behaviors and thoughts. The degree of lifetime trauma exposure experienced by children significantly impacts the degree to which they engage in aggressive behavior. Homeless related stressors contributed an incremental but statistically significant amount (3.3\%) to the overall variance of aggressive symptoms measured $(p<.05)$. The amount of stress experienced by homeless children is evident in their aggressive acts and feelings. This finding supports the 
hypothesis that both lifetime trauma and homeless related trauma significantly contribute to symptoms of aggression.

Table 4.11

Independent Variables on Aggression

\begin{tabular}{llll}
\hline & $\beta$ & $\mathrm{R}^{2}$ & $\Delta \mathrm{R}^{2}$ \\
\hline $\begin{array}{l}\text { 1. Gender } \\
\text { Age }\end{array}$ & .150 & .047 & .047 \\
Step One & .131 & & \\
2. ASTEQ-EM & $.619^{* *}$ & $.380^{* * *}$ & $.333^{* * *}$ \\
$\begin{array}{l}\text { Step Two } \\
\text { 3. HEQC-EM }\end{array}$ & $.203^{*}$ & $.412^{* * *}$ & $.033^{*}$ \\
$\quad$ Step Three & & & \\
\hline *p $<.05 * * \mathrm{p}<.01 * * * \mathrm{p}<.001 \mathrm{n}=81$ & & \\
Model Summary F $(4,76)=12.987 \mathrm{p}<.001$ & &
\end{tabular}

Regression Analysis of Independent Variables on TSCC-A Posttraumatic Scale

Table 4.12 illustrates the relationships between lifetime trauma, homeless related stress and posttraumatic symptomatolgy.

Table 4.12

Independent Variables on TSCC-A Posttraumatic Scale

\begin{tabular}{|c|c|c|c|}
\hline & $\beta$ & $\mathrm{R}^{2}$ & $\Delta \mathrm{R}^{2}$ \\
\hline 1. Gender & .006 & .022 & .022 \\
\hline Age & -148 & & \\
\hline $\begin{array}{l}\text { Step One } \\
\text { 2. ASTEQ-EM } \\
\text { Step Two }\end{array}$ & $.527^{* * *}$ & $.263^{* * *}$ & $242 * * *$ \\
\hline $\begin{array}{l}\text { 3. HEQC-EM } \\
\text { Step Three }\end{array}$ & $.203 * *$ & $.340^{* * *}$ & $.077^{* *}$ \\
\hline
\end{tabular}

After controlling for age and gender, lifetime trauma had a significant main effect upon posttraumatic symptoms. The numbers of lifetime traumatic exposures experienced by homeless 
children accounted for $24.2 \%$ of the variance in their symptoms of posttraumatic distress. The frequency of homeless related stressful exposures accounted for an additional $8 \%$ of the posttraumatic symptomatology experienced by sheltered children above and beyond that attributable to age, gender and lifetime trauma. This novel finding supports the hypothesis that posttraumatic symptoms are strongly associated with lifetime and homeless related exposures.

Regression Analysis of Independent Variables on TSCC-A Depression Scale

A statistically significant relationship was also found between lifetime trauma exposures and homeless related stressful experiences and symptoms of depression in this population of children.

Table 4.13 Independent Variables on TSCC-A Depression Scale

\begin{tabular}{llll}
\hline & $\beta$ & $\mathrm{R}^{2}$ & $\Delta \mathrm{R}^{2}$ \\
\hline $\begin{array}{l}\text { 1. Gender } \\
\text { Age }\end{array}$ & -.019 & .021 & .021 \\
Step One & -.140 & & \\
2. ASTEQ-EM & $.479 * * *$ & $.220 * * *$ & $.199 * * *$ \\
Step Two & & & \\
3. HEQC-EM & $.276^{*}$ & $.280 * * *$ & $.060 *$ \\
Step Three & & & \\
\hline * $\mathrm{p}<.05 * * \mathrm{p}<.01 * * * \mathrm{p}<.001 \mathrm{n}=81$ & & \\
Model Summary $\mathrm{F}(4,76)=7.198 \mathrm{p}<.001$ & &
\end{tabular}

After controlling for age and gender, lifetime exposures to trauma accounted for $20 \%$ of the variance in depression symptoms. This finding supports the hypothesis that the more lifetime trauma experienced by homeless children, the greater the likelihood is that they will suffer from depressive symptoms. Exposures to homeless related stress accounted for an additional $6 \%$ of the variance in depression symptoms, above and beyond that related to lifetime trauma exposures, age or gender. Homeless related stressors thus add significantly to the depressive 
thought, feelings and actions of homeless children. These data support the hypothesis that depression symptoms are strongly associated with lifetime trauma and homeless related stress.

Regression Analysis of Independent Variables on TSCC-A Anxiety Scale

After controlling for age and gender, lifetime traumatic exposures and homeless related exposures were measured on symptoms of anxiety.

Table 4.14

Independent Variables on TSCC-A Anxiety Scale

\begin{tabular}{|c|c|c|c|}
\hline & $\beta$ & $\mathrm{R}^{2}$ & $\Delta \mathrm{R}^{2}$ \\
\hline 1. Gender & -.098 & .055 & .055 \\
\hline Age & -.195 & & \\
\hline Step One & & & \\
\hline $\begin{array}{l}\text { 2. ASTEQ-EM } \\
\text { Step Two }\end{array}$ & $.470 * * *$ & $.247 * * *$ & $.192 * * *$ \\
\hline $\begin{array}{l}\text { 3. HEQC-EM } \\
\text { Step Three }\end{array}$ & .186 & $.274 * * *$ & .027 \\
\hline
\end{tabular}

Lifetime trauma had a strong main effect on symptoms of anxiety. Exposures to lifetime trauma accounted for $19.2 \%$ of the variance in anxiety symptoms in this population of children. These data suggest that the greater the frequency of lifetime trauma exposures experienced, the more likely that children will experience clinical levels of anxiety. Homeless related stressful exposures did not have a statistically significant effect on anxiety symptoms. These findings support the hypothesis linking lifetime traumatic exposures with anxiety symptoms. The hypothesis that homeless related stress would be associated with anxiety symptoms was unsupported. 
Regression Analysis of Independent Variables on TSCC-A Anger Scale

Lifetime trauma exposure accounted for $13 \%$ of the variance in anger symptoms in homeless children. Greater amounts of lifetime trauma exposure predict increased anger symptoms in homeless children, independent of age or gender. Homeless related stress did not predict anger symptoms in this population. These data support the hypothesis that there is $n$ association between lifetime trauma exposure and anger symptoms. The hypothesized relationship between homeless stress is not supported by these data.

Table 4.15

Independent Variables on TSCC-A Anger Scale

\begin{tabular}{|c|c|c|c|}
\hline & B & $\mathrm{R}^{2}$ & $\Delta \mathrm{R}^{2}$ \\
\hline 1. Gender & .078 & .014 & .014 \\
\hline Age & .076 & & \\
\hline Step One & & & \\
\hline $\begin{array}{l}\text { 2. ASTEQ-EM } \\
\text { Step Two }\end{array}$ & $.390 * * *$ & $.146^{* *}$ & $.132 * *$ \\
\hline $\begin{array}{l}\text { 3. HEQC-EM } \\
\text { Step Three }\end{array}$ & -.042 & $.148^{*}$ & .001 \\
\hline
\end{tabular}

The Contribution of the Moderating Variables on Mental Health Outcomes

Forty eight regression analyses were done to ascertain the moderating effect that perceived social support had on the pathways between trauma and mental health outcomes. Four interaction terms were created to test the relationship between lifetime trauma exposure and each of the six dependent variables representing mental health functioning. No statistically significant relationships were found between the lifetime trauma interaction terms and the dependent variables, and the hypothesis that perceived social support would impact mental health functioning was unsupported.. The moderating effect of perceived social support in the pathway between homeless related stress and mental health functioning was also tested by way of four 
created interaction terms. Again, no statistically significant relationship was found, and the hypothesis that perceived support would interrupt the pathway between homeless related stress and mental health outcomes was unsupported. These data suggest that the perceived support that children experience from mothers, fathers, siblings and best friends does not buffer them from the negative effects of lifetime trauma exposure or homeless related stress. 


\section{Chapter 5}

\section{Discussion}

This study examined the association between traumatic exposures experienced by homeless children and behavioral outcomes. Earlier research reported higher than average incidences of emotional distress and behavioral disturbances among sheltered children, but did not establish the psychological mechanisms that lead to such outcomes. The empirical findings derived from this study support observations that homeless families experience significant degrees of trauma.

Demographic information provided by mothers established that most children lived in single female headed households, had moved numerous times, and had attended several schools over the course of a year. Most families had been homeless more than one time. Once homeless, many children lived in a variety of transient settings before entering shelters; ranging from family or friend's houses, to extended stay hotels, to cars. A vast majority of mothers reported seeing changes in their children's behaviors that caused them concern.

\section{Lifetime Exposure to Traumatic Experiences}

Children's self reports revealed that this population of children experienced a variety of traumatic events at each level of their social ecologies. Not unexpectedly, many children experienced disjunction and discord in their families. Forty eight percent of children reported that currently they had siblings living away from the family unit. Families were also fractured by high rates of parental arrests and/or incarceration. Three fourths of children experienced the death of an important attachment figure. A majority of children had parents whose illnesses 
interfered with their care giving. Sixty-three percent of children described family environments colored by yelling and cursing. Approximately thirty percent of children reported being the recipient of emotionally abusive name calling by parents, whereas national averages for emotional abuse is seven percent (U.S. Department for Health and Human Services, 2005). For many of the children interviewed, the lack of stability and nurturance in their home environments laid the foundation for emotional distress and increased their vulnerability to trauma in other settings (Cicchetti, \& Lynch, 1993; Glassman, Weierich, Hooley, Deliberto, \& Nock, 2007; Grover, et al., 2007; Ickovics, Meade, Kershaw, Milan, Lewis \& Ethier, 2006; Kang, Deren, \& Goldstein, 2002; Lynch, \& Cicchetti, 2002; Ondersman, Delaney-Black, Covington, Nordstrom, \& Sokol, 2006; Whipple, 2006;).

According to a federal study, in 2005 of the children who were reported to state authorities for suspected maltreatment, $16.6 \%$ were found to be victims of physical abuse (U.S. Department of Health and Human Services Administration, 2005). In this study's sample of homeless children, twenty-two percent of participants reported physical abuse by a family member, yet many more (55\%) claimed physical abuse by a non-family member. The disparity in the responses suggests that children may have been under- reporting their physical victimization by parents. The under-reporting of parental abuse is plausible for several reasons. First, prior to giving their consent to participate in this study, parents and children were apprised, in age appropriate language, of the limitations of confidentiality. To some degree, children may have understood the risk attendant to divulging abuse. Second, in the course of interviews, some families expressed apprehension at being "kicked out" of shelters, and children may have felt pressured to present their parents and themselves in the best light. Third, it is well documented that most children are unlikely to disclose painful or shameful experiences to strangers, 
especially where trust has not been developed (Coffey, Leitenberg, Henning, Turner \& Bennett, 1996; Feiring, Taska, \& Chen, 2002; Hershkowitz, Horwitz, \& Lamb, 2007). Whereas 21\% of children reported sexual abuse compared to the national average of $9 \%$ (U.S. Department of Health and Human Services Administration, 2005), for the reasons given, it is possible that the number of actual sexual abuse victims was higher (London, Bruck, Ceci, \& Shuman, 2005; Somer \& Szwarcberg, 2001). Child maltreatment in the form of physical, sexual or emotional abuse is traumatic and has devastating and long term psychological consequences for its victims (Briere \& Spinazzola, 2005; Coffey, Leitenberg, Henning, Turner \& Bennett, 1996a; Faust, \& Katchen, 2004; Ford, et al., 2000; Garbarino, 2001; Glassman, Weierich, Hooley, Deliberto \& Nock, 2007; Grover, et al., 2007; Kang, Deren, \& Goldstein, 2002; Kuperminc \& Brookmeyer, 2006; Miller, 1999; Street, Gibson, \& Holohan, 2005; Pynoos, Steinberg \& Piacentini,1999; Whipple, 2006).

Many children reported witnessing domestic violence and physical assaults between unrelated adults. Nineteen percent of children reported witnessing someone harming their siblings. Thirty-three percent reported breaking up fights between family members. Children also observed interpersonal violence that occurred in other families, including that which took place while residing in shelter settings. A robust literature has established the harmful psychological consequences to children who observe physical assaults or intimate partner violence (Becker \& McCloskey, 2002; Coyne, Barrett \& Duffy, 2000; Cummings, Peplar, \& Moore, 1999; Groves, 1999; Kitzman, Gaylord \& Holt, 2003). For many of the children interviewed, domestic violence was a precipitant to homelessness. It is conceivable that the emotional damage derived from seeing a parent abused, and a child's concerns for that parent's safety as well as their own is exacerbated by the need to escape from a familiar home setting (Anooshian, 2005; Becker \& 
McCloskey, 2002; Cummings, Pepler, \& Moore, 1999). Most victims of domestic violence, once they leave an abusive home setting, continue to feel unsafe (Coyne, Barrett \& Duffy, 2000; Smith \& Landreth, 2003). Externalizing and internalizing behaviors would be anticipated in children who have been exposed to interpersonal violence, who have left their homes for new and unknown surroundings, and who have not had the opportunity to heal.

The attachment and trauma literatures converge when seeking to better understand the psychological experiences of abused and neglected children (Briere \& Spinazzola, 2005;

Cicchetti, \& Lynch, 1993; Cook, et al., 2005; Lynch \& Cicchetti, 2005; Stovall-McClough, \& Cloitre, 2006). In order to form healthy, organized attachments with others, children require secure, consistent relationships with caregivers who recognize and respond appropriately to their developmental needs (Bowlby, 1969, 1973; Herring, \& Kaslow, 2002; Lynch \& Cicchetti, 2002). From birth onwards the nature and quality of attachment bonds provides the individual with internalized models of self, conceptualizations of relationships with others, and modes of relating to and with others (Bowlby, 1969,1973; Herring and Kaslow, 2002). Lynch \& Cicchetti (2002), Herring and Kaslow (2002), Cook and colleagues (2005), and others have demonstrated that parents who themselves have disorganized, insecure or ambivalent attachments, who are overburdened by illnesses, addictions or life events, are often unable to provide their children with the secure foundation needed for healthy development. Moreover, highly stressful experiences in adults' lives, such as homelessness, have been found to re-activate both parental experiences of trauma and the chaos of earlier insecure attachments, thus making parents even less available to children in times of great need (Lynch, \& Cicchetti, 2002; Nader, 1997). Children who form disorganized/ insecure or ambivalent attachments are less likely to trust or expect their parents and others to provide them with comfort or protection, and as a result, are 
likely to feel depressed, anxious, isolated and unsupported (Byng-Hall, 2002; Herring, \& Kaslow, 2002; Stovall-McClough, \& Cloitre, 2006). The internalization of negative self-schema as well as the cognitive and psychological disturbances that result from insecure or disorganized attachments have lifelong ramifications (Bowlby, 1969, 1973; Cook, et al., 2005; Herring, \& Kaslow, 2002). According to trauma theorists, abuse has an overwhelming psychological impact on children because it interferes during critical developmental periods with emotional regulation and identity formation. (Briere, 1988; Briere \& Spinazzola, 2005; Cook, et al., 2005; StovallMcClough, \& Cloitre, 2006; Van der Kolk, et al., 2005). Children do not have the cognitive or psychological resources to "make sense" of their abuse, and often blame themselves, especially when they are violated by caretakers (Briere, 1988; Coffey, Ickovics, et al., 2006; Leitenberg, Henning, Turner, \& Bennett, 1996a; Feiring, Taska, \& Lewis, 2002; Stovall-McClough \& Cloitre, 2006; Street, Gibson \& Holohan, 2005). Lacking reassurance, validation or the coping mechanisms to integrate their abusive experiences, children have been found to develop traumatic responses including hyper-arousal, dissociation, emotional dysregulation, intrusive thoughts, numbing, aggression and interpersonal difficulties (Ackerman, et al., 1998; Briere \& Spinazzola, 2005; Cook, et al., 2005; van der kolk, et al., 2005). Abused and neglected children most commonly carry diagnoses of separation anxiety, oppositional defiant disorder, posttraumatic stress, phobias, ADHD, anger and aggression (Ackerman, et al. 1998; Nader, 1997; Van der Kolk, et al., 2005). Without effective treatment, adolescent and adult survivors of childhood trauma have lifetime manifestations of psychiatric morbidity including: borderline personality disorders, posttraumatic or complex stress, affective and mood disorders, eating and sleep disorders, substance abuse and somatic complaints (Briere \& Spinazzola, 2005; Moskvina, et al., 2007; Van der Kolk, et al., 2005). Nonetheless, many children do not experience clinical 
levels of psychological distress following trauma. Why some homeless children tend to be more resilient than others is not well understood, and requires further investigation.

Childhood exposure to community violence has been associated with antisocial behavior, internalizing and externalizing disorders and school failure (Bailey, Hannigan, Delaney-Black, Covington \& Sokol, 2006; Gorman-Smith \& Tolan, 1998; Ondersma, DelaneyBlack, Covington, Nordstrom \& Sokol, 2006). Poor psychological outcomes are prevalent in both victims and witnesses of acts of community violence (Bailey, Hannigan, Delaney-Black, Covington, \& Sokol, 2006; Gorman-Smith \& Tolan, 1998; Margolin, \& Gordis, 2000). Sixtyfour percent of children in this study reported hearing gunshots in their neighborhoods. Almost thirty percent of children witnessed a shooting, drug bust or gang fight. Twenty seven percent of children saw adults using illegal drugs, again, a finding that was likely to be under-reported. ${ }^{3}$ In some settings, strong social networks, consistent boundaries and authoritative parenting styles have been found to moderate the overwhelmingly negative effects of community violence (Bailey, Hannigan, Delaney-Black, Covington, \& Sokol, 2006; Barrera, 2000; Barrera, Prelow, et al, 2002; Gorman-Smith \& Tolan, 1998; Klierwer, et al, 2004; Maton, 1989 ;Overstreet \& Dempsey, 1999; Pettit, Bates \& Dodge, 1997; Sullivan, Kung \& Farrell, 2004, Syzukula, Mas, Turner, Crowley, \& Sayger, 1991). Whereas homeless parents have been found to lack strong social networks, to be highly stressed, and to be themselves traumatized, it was expected that many their children would be especially susceptible to the deleterious effects of community violence (Gorman-Smith \& Tolan, 1998; Ondersma, Delaney-Black, Covington, Nordstrom, \& Sokol, 2006).

\footnotetext{
${ }^{3}$ Many mothers informally provided information about their substance abuse. It is anticipated that many more than $27 \%$ of children observed an adult, including their mothers using illegal substances.
} 
The negative impact of lifetime trauma on psychological functioning was evident in the emotional distress experienced by this population of children. After controlling for age and gender, exposure to traumatic events within homes and in the community contributed to significant amounts of the variance in symptoms of depression, anxiety, aggression, anger, and posttraumatic stress. The association between lifetime trauma exposures and symptoms of emotional distress in homeless children is a novel finding, and provides and important lens through which to understand the psychological presentation of this population.

\section{Exposure to Stressful and Traumatic Experiences Related to Homelessness}

A new contribution of the present study is that it assessed stressful and traumatic experiences directly related to the experience of homelessness. The Homeless Experiences Questionnaire for Children (HEQC) was developed for this study, and enabled children to identify highly stressful or traumatic experiences that occurred in the context of becoming homeless. Children reported that they sustained significant losses: their important possessions, their family autonomy, and access to special friends and, in some instances, family members. The upheaval in the lives of many children was intensified by the experiences of shelter living: proximity to strangers, some of whom were experienced as threatening or unsafe and the need to learn and adhere to new rules. Almost all children reported moving from one type of shelter program to another, each with new people, personnel, and different expectations of residents. Some shelters were comprised of large congregant settings where multiple families lived in one overcrowded room, with each person getting a bunk bed, and no private space. Congregant type shelters were not limited to homeless families, and many adult residents appeared to be chronically mentally ill. Other programs included families housed in small rooms or units with 
common eating and bathroom facilities. A third type of longer term shelter program consisted of families housed in small apartments in a complex. Many of the programs required that children leave early in the mornings with their mothers and not return until nightfall.

Thirty six percent of children observed that their mother's behavior had changed since becoming homeless, and sixty eight percent of children reported having to help their mothers in new and difficult ways. Shelter personnel observed that in some instances mothers appeared to rely heavily on one identified child in their family to assume caretaking roles of both her and her other children. The reconfiguration of family hierarchies and destructive parentification or unjust filial responsibility may lead to emotional loss, depression and anxiety (Byng-Hall, 2002; Jurkovic, 1997). It should also be noted that under some circumstances, filial responsibilities can be an important protective factor for children growing up under highly stressful circumstances, including chronic poverty, war, and immigrant or refugee resettlement (Byng-Hall, 2002; Jurkovic, 1997; Jurkovic, Kuperminc, Sarac, \& Weishaar, 2005).

Upon becoming homeless, seventy percent of children had to change schools and many children reported continued poor attendance. The psychological consequences of frequently changing schools and irregular attendance cannot be overestimated (Rafferty, 1995; Yamaguchi, et al., 1997). For many children, school provides a stabilizing, structured environment where important attachments can be formed with peers and adults. Transitions to new schools can contribute to children's feelings of isolation and anxiety (Rafferty \& Shinn, 1991). Anxiety is likely to increase when children fall behind at school due to poor attendance. Grade retention furthers stigmatization and the loss of peer groups (Rafferty, 1993; Ziskus, \& Gottlieb, 1979). In this sample of children, thirty four percent reported repeating a grade; some children stayed back more than one time. For homeless children, the trajectory of changing schools numerous times, 
ongoing poor attendance, falling behind and repeating grades may be experienced as significant and cumulative stressors that contribute to emotional disturbances.

After controlling for age, gender and lifetime trauma, the traumatic or highly stressful experiences of homelessness accounted for a significant and independent increment of the variance in the symptoms of depression, aggression and posttraumatic stress experienced by this population of children. Unexpectedly, homeless related complex stress did not have a main effect on anger symptoms. It is not clear whether this finding is an artifact of the measures used to understand the association between trauma exposure and anger in this population. Further research is needed to better understand anger symptoms among homeless children.

The empirical association between homeless related trauma and emotional distress is a novel finding and adds an important dimension to the literature of the mental health functioning of homeless children. These data support what has long been observed anecdotally by providers in programs that serve homeless families.

\section{The Moderating Role of Perceived Social Support}

Many children who are homeless do not suffer clinical levels of emotional distress, and it is important to understand why. This study demonstrated that a majority of children do not experience clinical ranges of emotional or behavioral distress, despite exposures to both lifetime trauma and homeless related stress. It was expected that relationships with parents, siblings and best friends would provide a buffer in the pathways between traumatic exposures and mental health morbidity (Bailey, Hannigan, Delaney-Black, Covington, \& Sokol, 2006; Branje, van Lieshout, van Aken, \& Haselager, 2004; Cauce, 1986; Gavazzi, 1994; Hammack, Richards, Luo, Edlyn, \& Roy, 2004; Lempers \& Clark-Lempers, 1992; Milevsky \& Levitt, 2005; Slavin, \& 
Rainer, 1990; Szykula, Mas, Turner, Crowley \& Sayger, 1991). Unexpectedly, children's perceptions of supportive relationships with parents, siblings, and best friends did not affect the degree of clinical symptomatology experienced.

There are several explanations for why perceived social support may not have moderated the relationship between traumatic exposure and mental health morbidity. As noted before, many neglected and abused children have insecure or disorganized attachments (Lynch, \& Cicchetti, 2002; Nader, 1997; Stovall-McClough, \& Cloitre, 2006). Children with unhealthy attachments are less likely to perceive and experience their caregivers, or others, as capable of providing support (Bowlby, 1969, 1973; Herring, \& Kaslow, 2002). This lack of expectation limits the protective role that might otherwise be available from important relationships. Second, because homeless mothers tend to have little actual social support for themselves (Anooshian, 2005; Masten, et al, 1993), it is possible that their children lack models that enable them to them to imagine others coming to their assistance in times of need. Third, it is conceivable that the acute crisis of homelessness diminishes the protection often derived from perceived social support. Most of the children who participated in this study were relatively "new" to homelessness and were likely to have parents and siblings who were also highly stressed, depressed, and unavailable to provide them with needed emotional resources. Overwhelmed by their own reactions to past and recent lifetime trauma, and to the traumatic experiences of their children, mothers may not have been able to provide the validation, tolerance or reassurance needed by children to foster healthy attachment at such a stressful time (Cook, Spinazzola, et al, 2005; Lynch \& Cicchetti, 2002; Schumm,Stines, Hobfall \& Jackson, 2005; Street, Gibson \& Holohan, 2005). At the same time, many homeless children, forced to move from old neighborhoods and schools, were completely disconnected from usually 
supportive peers (Masten et al, 1993, Rafferty \& Shinn, 1991). These acute conditions may diminish the protective effect that would otherwise be expected from significant peer relationships. A fourth reason that perceived social support was not significantly associated with mental health outcomes may have had to do with characteristics of the sample studied. The relatively small sample involved children ranging in ages 8-16. A majority of the children were eleven years old or younger. A growing literature has investigated the differences in perceived social support across childhood with peer support replacing parent and sibling support in importance as children reach middle school and adolescence (Branje, van Lieshout, van Aken, \& Haselager, 2004; Cauce, 1986; Furman \& Buhrmeister, 1992; Lempers \& Clark-Lempers, 1992; Milevsky \& Levitt, 2005; Slavin \& Rainer, 1990). It is possible that a larger sample would provide the power necessary to detect a meaningful effect of perceived social support across childhood.

Notwithstanding the lack of empirical support for a moderating effect from perceived social support of parents, siblings and best friends in this population, it is important to understand why many homeless children do relatively well. Identifying mechanisms that support children's strengths is as critical as introducing clinical interventions for those who are not faring well psychologically.

\section{Limitations and Further Research Directions}

Recognizing the significant trauma that homeless children endure is critical to those who work with this vulnerable population. Trauma presentations in children can be masked by a misunderstanding of symptomatology, and failure to treat trauma may cause continued exposures, placing many children at risk for immediate harm as well as long term dysfunction (Briere \& Spinazzola, 2005; van der Kolk \& Courtois, 2005; van der Kolk, et al., 2005). 
Children who have untreated trauma are likely to endure cumulative traumatic exposures over the course of their lifetimes, placing themselves and others at risk (Cook, et al., 2005; Schumm, Stines, Hobfall, \& Jackson, 2005). Indeed, many homeless parents, in this and other studies, report unresolved childhood trauma (Anooshian, 2005; Browne, 1993; Burt \& Laudan, 2000). Trauma oriented mental health interventions directed towards sheltered children and their families are imperative and should be a central component of programmatic design. Shelter personnel need training and support in understanding the psychological presentation of many of the families they serve, and must strive to create "trauma sensitive environments" for their clients. Follow up clinical services and other social supports should be provided to children and parents once they become housed. Policy makers must understand that funding mental health services for this population is not only a critical intervention tool, but may prevent the continuing cycle of homelessness across generations.

A strength of the study involved the multiple informants (parents and children) that provided empirical data on the mental health functioning of homeless children. Again, this appears to be a novel approach to studying this population. The response biases as well as the discrepancies inherent in parent observations versus children's reports of symptoms were noted but not fully understood. A question is raised as to whether discrepancies between parent and child reports is simply the difference between self versus other perspectives on emotional functioning, or whether it underscores important psychological information about parent functioning including depression, attachment, and trauma. Further research into these important questions is needed.

Limitations of the study involved the small size and relative homogeneity of the participants. Most participants were relatively new to being homeless. Additional research 
should address the impact of perceived social support at different ages and at varying stages of homelessness. Further research with a larger sample might address the role of social support across various developmental periods. Another limitation of the research involved the lack of cross sectional design. While a relatively robust literature has studied differences between homeless children and housed low income children with conflicting results (Bassuk, et al., 1997; Bassuk \& Rosenberg, 1990; Masten, et al., 1993) none to date has identified trauma exposure as a critical psychological construct of experience. The novel findings of this study may inform the literature and contribute to better understanding of at risk children in important ways.

An ongoing challenge of research in this area involves access to homeless families. Identifying homeless families who may be willing to participate in research presents logistical and methodological concerns. Finding and gaining access to homeless families proves daunting. Many families once located are understandably wary of speaking with strangers about highly personal and often painful events. Parents also risked exposure for practices that amounted to child abuse and/or neglect, and for that reason, many potential participants declined to be studied. It was not possible to estimate how many parents declined to participate in the study for this or other reasons, as shelter residents had the choice to not attend informational meetings, and many of those that did attend excluded themselves for a variety of reasons (age of children etc) Forming professional alliances with shelter personnel about the importance of the research proved central to being invited into shelter settings. Explaining to parents the potential benefits of the research findings to other homeless families through the vehicle of improved mental health services appeared to persuade families to consent to participation. Furthermore, aligning with parents' overwhelming concerns for their children's' mental health was key. Recognizing 
the inherent strengths in homeless families and their right to better existences is crucial to further research, clinical interventions and program design.

The response to empirically supported findings of the long observed relationship between lifetime trauma exposure, homeless related stress and mental health difficulties cannot be limited to programmatic design and clinical intervention. Homelessness is the product, in large part, of a society that has been willing to look the other way. At each level of their social ecologies, high risk, low income families are highly stressed, isolated and unsupported. Job training, affordable day care, and accessible transportation creates financial stability for families. Availability of health care, including mental health and substance abuse services is critically needed to heal those who may otherwise remain sick and impoverished. After school and mentoring programs for high risk children must be established, and financially sustained. Advocates and activists must join forces with clinicians to present social and political initiatives to give voice to the needs of homeless and other high risk low income children. 


\section{REFERENCES}

Ackerman, P.T., Newton, J.E.O., McPherson, W.B., Jones, J.G., \& Dykman, R.A. (1998). Prevalence of posttraumatic stress disorder and other psychiatric diagnoses in three groups of abused children (sexual, physical, and both). Child Abuse and Neglect, 22(8), 759-774.

American Academy of Pediatrics, Committee on Community Health Services. (2005). Providing care for immigrant, homeless, and migrant children. Pediatrics, 115, 1095-1100.

American Psychiatric Association. (1994). Diagnostic and statistical manual of mental disorders ( $4^{\text {th }}$ ed.). Washington, DC: Author.

Anooshian, L.J. (2005). Violence and aggression in the lives of homeless children: A review. Aggression and Violent Behavior, 10, 129-152.

Attar, B.K., Guerra, N.G., \& Tolan, P.H. (1994). Neighborhood disadvantage, stressful life events, and adjustment in urban elementary school children. Journal of Clinical Child Psychology, 23, 391-400.

Bailey, B., Hannigan, J.H., Delaney-Black, V., Covington, C., \& Sokol, R.J. (2005). The role of maternal acceptance in the relation between community violence exposure and child functioning. Journal of Abnormal Child Psychology, 34(1), 54-67.

Ball, J., Jurkovic, G., Barber, C.N., Armistead, L., Koon, R., \& Zucker, M. (in press). The relationship between community violence and psychological outcomes in incarcerated male adolescents: Family factors as moderators. The Journal of Aggression, Mistreatment and Trauma.

Barrera, Jr., M. (2000). Social Support Research in Community Psychology. In J. Rappaport \& E. Seidman (Eds.), Handbook of Community Psychology, New York: Kluwer Academic/Plenum Publishers.

Barrera, M., Prelow, H.M, Dumka, L.E., Gonzales, N.A, Knight, G.P., Michaels, M.L., et al. (2002). Pathways from family economic conditions to adolescents' distress: Supportive parenting, stressors outside the family and deviant peers. Journal of Community Psychology, 30, 135-153.

Baron, R.M., \& Kenny, D.A. (1986). The moderator-mediator variable distinction in social psychological research: Conceptual, strategic, and statistical considerations. Journal of Personality and Social Psychology, 51, 1173-1182.

Bassuk, E. (1993). Social and economic hardships of homeless and other poor women. American Journal of Orthopsychiatry, 63, 340-347. 
Bassuk, E., \& Rosenberg, L. (1990). Psychosocial characteristics of homeless children and children with homes. Pediatrics, 85, 257-261.

Bassuk, E.L., Buckner, J.C., Weinreb, L.F., Browne, A., Bassuk, S.S., \& Perloff, J.N. (1997). Homelessness in female-headed families: Childhood and adult risk and protective factors. American Journal of Public Health, 87(2), 241-248.

Bearer, C.F. (1995). Environmental health hazards: How children are different from adults. The Future of Children, 5(2), 1-26.

Becker, K.B., \& McCloskey, L.A. (2002). Attention and conduct problems in children exposed to family violence. American Journal of Orthopsychiatry, 72, 83-91.

Berck, J. (1992). No Place to Be: Voices of Homeless Children. Boston, MA: Houghton Mifflin Co.

Bowlby, J. (1969). Attachment and Loss, Vol.1: Attachment. New York: Basic Books.

Bowlby, J. (1973). Attachment and Loss, Vol.2: Separation. New York: Basic Books.

Branje, S.J.T., van Lieshout, C.F.M., van Aken, M.A.G., \& Haselager, G.J.T. (2004). Perceived support in sibling relationships and adolescent adjustment. Journal of Child Psychology and Psychiatry, 45(8), 1385-1396.

Briere, J. (1988). The long-term clinical correlates of childhood sexual victimization. In R.A. Prentky \& V.L. Quinsey (Eds.), Annals of the New York Academy of Sciences: Vol, 528. Human sexual aggression: Current perspectives (pp. 327-334). New York: New York Academy of Sciences.

Briere, J. (1996a). Trauma Symptom Checklist for Children (TSCC) Professional Manual. Odessa, FL: Psychological Assessment Resources.

Briere, J. (1996b). Psychometric review of the Trauma Symptom Checklist for Children. In B.H. Stamm (Ed.), Measurement of stress, trauma, and adaptation.(pp. 1-10) Lutherville, MD: Sidran Press.

Briere, J. \& Spinazzola, J. (2005) Phenomenology and psychological assessment of complex posttraumatic states. Journal of Traumatic Stress, 18 (5),401-412.

Bronfenbrenner, U. (1977). Toward an experimental ecology of human development. American Psychologist, 32, 513-531.

Bronfenbrenner, U. (1979). The ecology of human development. Cambridge, MA: Harvard University Press. 
Browne, A. (1993). Family violence and homelessness: The relevance of trauma histories in the lives of homeless women. American Journal of Orthopsychiatry, 63, 370-384.

Buckner, J.C., Bassuk, E.L., Weinreb, L.F., \& Brooks, M.G. (1999). Homelessness and its relation to mental health and behavior of low-income school age children. Developmental Psychology 35, 246-57.

Burg, M. (1994). Health problems of sheltered homeless women and their dependent children. Health \& Social Work, 19, 125-131.

Burt, M., \& Laudan, A. (2000). America's Homeless II: Populations and Services. The Urban Institute. (numbers)

Byng-Hall, J. (2002). Relieving parentified children's burdens in families with insecure attachment patterns. Family Process, 41(3), 375-388.

Cauce, A.M. (1986) Social networks and social competence: Exploring the effects of early adolescent friendships. American Journal of Community Psychology, 14(6), 607-628.

Carter, C.S. (2002). Perinatal care for women who are addicted and implications for empowerment. Health and Social Work, 27(3), 166-174.

Children's Defense Fund (2000). The State of America's Children: Yearbook 2000. Washington, DC: Children's Defense Fund.

Cicchetti, D., \& Lynch, M. (1993). Towards an ecological/transactional model of community violence and child maltreatment: Consequences for children's development. Psychiatry, 56, 96-118.

Coffey, P., Leitenberg, H., Henning, K., Turner, T., \& Bennett, R.T. (1996a). Mediators of the long-term impact of child sexual abuse: Perceived stigma, betrayal, powerlessness, and self-blame. Child Abuse and Neglect, 20, 447-455.

Conger, R.E., Ge, X., Elder, G.H., Lorenz, F.O., \& Simmons, F.L. (1994). Economic stress, coercive family process, and developmental problems of adolescents. Child Development, $65,541-561$.

Cowan, B.A., Kuperminc, G. P., \& Jurkovic, G. J. (2005). The Homeless Experiences Questionnaire for Children. Unpublished measure.

Cowan, B.A., Jurkovic, G. J. \& Kuperminc, G.P. (2005). The ASTEQ- Brief Version (ASTEQlite). Unpublished measure.

Coyne, J.J., Barrett, P.M., \& Duffy, A.L. (2000). Threat vigilance in child witnesses of domestic violence: A pilot study utilizing the ambiguous situation paradigm. Journal of Child and Family Studies, 9(3), 377-388. 
Cummings, J.G., Pepler, D.J., \& Moore, T.E. (1999). Behavior problems in children exposed to wife abuse: Gender differences. Journal of Family Violence, 14, 133-156.

Davey, T.L. (2004). A multiple family group intervention for homeless families: The weekend retreat. Health and Social Work, 29, 326-329.

DeVicente, A., Muñoz, M., Perez-Santos, E., \& Santos-Olmo, A.B. (2004). Emotional disclosure in homeless people: A pilot study. Journal of Traumatic Stress, 17(5), 439-443.

Donahue P.J., \& Tuber, S.B. (1995). The impact of homelessness on children's level of aspiration. The Bulletin of the Menninger Clinic, 59 (1), 1-10.

Douglass, A. (1996). Rethinking the effects of homelessness on children: Resiliency and competency. Child Welfare, 75, 741-51.

Faust, J., \& Katchen, L.B. (2004). Treatment of children with complicated posttraumatic stress reactions. Psychotherapy: Theory, Research, Practice, Training, 41, 426-437.

Fasulo, S.J. (2007). Complex trauma exposure and psychological outcomes in incarcerated offenders. Unpublished doctoral dissertation, University of Georgia.

Feiring, C., Taska, L.S., \& Chen, K. (2002). Trying to understand why horrible things happen: Attribution, shame, and symptom development following sexual abuse. Child Maltreatment, 7, 26-41.

Follette, V.M., Polusny, M.A., Bechtle, A.E., \& Naugle, A.E. (1996). Cumulative trauma: The impact of child sexual abuse, adult sexual assault and spouse abuse. Journal of Traumatic Stress, 9, 25-35.

Ford, J.D., Racusin, R., Ellis, C.G., Davis, W.B., Reiser, J., Fleisher, A., et al. (2000). Child maltreatment, other trauma exposure and posttraumatic symptomatology among children with oppositional defiant and attention deficit disorder. Child Maltreatment, 5(3), $205-$ 217.

Friedman, D.H. (2000). Parenting in Public . New York, NY: Columbia University Press.Friedman, D.H., Meschede, T., \& Hayes, M. (2003). Surviving against the odds: Families' journeys off welfare and out of homelssness. Cityscape: A Journal of Policy Development and Research, 6(2), 187-206.

Furman, W., \& Buhrmester, D. (1992). Age and sex differences in perceptions of networks of personal relationships. Child Development, 63, 103-115.

Garbarino, J. (2001). An ecological perspective on the effects of violence on children. Journal of Community Psychology, 29, 345-361. 
Gavazzi, S.M. (1994). Perceived social support from family and friends in a clinical sample of adolescents. Journal of Personality, 1, 465-471.

Glassman, L., Weierich, M.R., Hooley, J.M., Deliberto, T.L., \& Nock, M.K. (2007) Child maltreatment, non-suicidal self injury and the mediating role of self-criticism. Behavior Research and Therapy, 45(10), 2483-2490.

Gorman-Smith, D. \& Tolan, P. (1998). The role of exposure to community violence and developmental problems among inner city youth. Development and Psychopathology, 10, 101-116.

Graham-Bermann, S.A., Coupet, S., Egler, L., Mattis, J., \& Banyard, V. (1996). Interpersonal relationships and adjustment of children in homeless and economically distressed families. Journal of Clinical Child Psychology, 25, 250-261.

Greenwald, R., \& Rubin, A. (1999). Assessment of posttraumatic symptoms in children: Development and preliminary validation of parent and child scales. Research on Social Work Practice, 9(1), 61-75.

Greenwald, R., Rubin, A., Jurkovic, G.J., Weidemann, J., Russell, A.M., O’Connor, M.B., et al. (2002, June). Psychometrics of the CROPS and PROPS in multiple cultures/translations. Poster session presented at the meeting of the International Society for Traumatic Stress, Baltimore, MD.

Grover, K., Carpenter, L.L., Price, L.H., Gagne, G.G., Mello, A.F., Mello, M.F., \& Tyrka, A.R. (2007). The relationship between childhood abuse and adult personality disorders. Journal of Personality Disorders, 21(4), 442-447.

Groves, B.M. (1999) Domestic violence and children. The Future of Children, 9(3), 122-132.

Goodman, L., Saxe, L., \& Harvey, M. (1991). Homelessness and psychological trauma: Broadening perspectives. American Psychologist, 46, 1219-1225.

Gorman-Smith, D., \& Tolan, P. (1998). The role of exposure to community violence and developmental problems among inner-city youth. Development and Psychopathology, 10, 101-116.

Haden, S.C., Scarpa, A., Jones, R.T., \& Ollendick, T.H. (2007). Posttraumatic stress disorder symptoms and injury: The moderating role of perceived social support. Personality: Individual Differences, 42(7), 1187-1198.

Hammack, P.L., Richards, M.H., Luo, Z., Edlynn, E.S., \& Roy, K. (2004). Social support factors as moderators of community violence exposure among inner-city African American young adolescents. Journal f Clinical child and Adolescent Psychology, 33(3), 450-462.

Hans, S.L. (1999). Demographics and psychosocial characteristics of substance abusing pregnant women. Clinics in Perinatology, 26(1), 55-74. 
Hausman, B., \& Hammen, C. (1993). Parenting in homeless families: The double crisis. American Journal of Orthopsychiatry, 63, 358-369.

Herring, M. \& Kaslow, N. (2002). Depression and attachment in families: A child-focused perspective. Family Process, 41 (3), 494-418.

Hershkowitz, I., Lanes, O., Lamb M.E. (2007). Improving credibility assessments in children's sexual abuse allegations: The role of the NICHD investigation interview protocol. Child Abuse \& Neglect, 31 (2), 111-123.

Hoge, E.A., Austin, E.D., \& Pollack, M.H. (2007). Resilience: Research evidence and conceptual considerations for posttraumatic stress disorder. Depression and Anxiety, 24(2), 139-152.

Ickovics, J.R., Meade, C.S., Kershaw, T.S., Milan, S, Lewis, J.B. \& Ethier, B. (2006). Urban teens: Trauma, posttraumatic growth, and emotional distress among female adolescents. Journal of Counseling and Clinical Psychology, 74(5), 841-850.

Jackson, Y.K., Kim, K.L., \& Delap, C. (2007). Mediators of control beliefs, stressful life events and adaptive behaviors in school age children: The role of appraisal and social support. Journal of Traumatic Stress, 20(2), 147-160.

Jurkovic, G.J. (1997). Lost Childhoods: The plight of the parentified child. New York: Brunner/Mazel.

Jurkovic, G.J., Kuperminc, G.P., Sarac, T., \& Weishaar, D. (2005). Role of filial responsibility in the post-war adjustment of Bosnian young adolescents. Journal of Emotional Abuse, 5(4), 219-235.

Kang, S., Deren, S., \& Goldstein, M.F. (2002). Relationships between childhood abuse and neglect experiences and HIV risk behaviors among methadone treatment dropouts. Child Abuse and Neglect, 26(12), 1275-1289.

Kilpatrick, D.G., Ruggeiero, K.J., Acierno, R., Saunders, B.E., Resnick, H. S. \& Best, C.L. (2003). Violence and risk of PTSD, major depression, substance abuse/dependence and comorbidity: Results from the National Survey of Adolescents. Journal of Consulting and Clinical Psychology, 71, 692-700.

Kilmer, R.P., Cowen, E.L., \& Wyman, P.A. (2001). A micro-level analysis of developmental, parenting and family milieu variables that differentiate stress-resilient and stress-affected children. Journal of Community Psychology, 29, 391-416.

Kitzman, K.M., Gaylord, N.K., \& Holt, A.R. (2003). Child witnesses to domestic violence: A meta-analytic review. Journal of Consulting and Clinical Psychology, 71 (2), 339-352. 
Klerman, L.V. (1992). Nonfinancial barriers to the receipt of health care. The Future of Children, 2(2), 173-187.

Kliewer, W., Cunningham, J.N., Diehl, R., Parrish, K.A., Walker, J.M., Atiyeh, C., Neace, B., Duncan, L., Taylor, K.,\& Meija R. (2004) Violence exposure and adjustment in innercity youth: Child and caregiver emotional regulation skill, caregiver-child relationship quality and neighborhood cohesion as protective factors (2004). Journal of Clinical Child and Adolescent Psychology, 33(3), 477-487.

Krieger, J., \& Higgins, D.L. (2002). Housing and health: time again for public health action. American Journal of Public Health, 92(5), 758-768.

Kozol, J. (1988). Rachel and her Children: Homeless Families in America. New York, NY: Ballantine Books.

Kuperminc, G.P., \& Brookmeyer, K.A. (2006). Developmental psychopathology. In R. Ammerman (Ed.), Comprehensive Handbook of Personality and Psychopathology : Vol. 3 (pp.1-10). New York: Wiley.

Lauterbach, D., Bak C., Reiland, S., Mason, S., M.R., \& Earls, M. (2007). Quality of parental relationships among person with a lifetime history of posttraumatic stress disorder. Journal of Traumatic Stress, 20(2), 161-172.

Leadbeater, B.J., Kuperminc, G.P., Blatt, S.J., Herzog, C. (1999). A multivariate model of gender differences in adolescents' internalizing and externalizing problems. Developmental Psychology, 35, 1268-1282.

Lempers, J.D., \& Clark-Lempers, D.S. (1992). Young, middle and late adolescents'comparisons of the functional importance of five significant relationships. Journal of Youth and Adolescence, 21 (1), 53-96. (NRI)

Livert, D. \& Hughes, D.L. (2002). The ecological paradigm: Persons in Settings. In T.A. Revenson, et. al (Eds.), A Quarter Century of Community Psychology: Readings from the American Journal of Community Psychology, (pp. 1-10). New York: Kluwer Academic/Plenum Publishers.

Loeber, R., Green, S.M., \& Lahey, B.B. (1990). Mental health professionals' perceptions of the utility of children, mothers, and teachers as informants on childhood psychopathology. Journal of Clinical Child Psychology, 19, 136-143.

London, K., Bruck, M., Ceci, S.J., \& Shuman, D.W. (2005). Disclosure of child sexual abuse: What does the research tell us about the ways children tell? Psychology, Public Policy and Law, 11(1), 194-226.

Luthar, S.S., Cicchetti, D., \& Becker, B. (2000). The construct of resilience: A critical evaluation and guidelines for future work. Child Development, 71(3), 543-562. 
Lynch, M., \& Cicchetti, D. (1998). An ecological-transactional analysis of children and contexts: The longitudinal interplay among child maltreatment, community violence, and children's symptomatology. Development and Psychopathology, 10, 235-257.

Lynch, M., \& Cicchetti, D. (2002). Links between community violence and family systems Evidence from children's feelings of relatedness and perceptions of parent behavior. Family Process, 41, 519-532.

Masten, A. S., Miliotis, D., Graham-Bermannn, S.A., Ramirez, M., \& Neemann, J. (1993). Children in homeless families: Risks to mental health. Journal of Consulting and Clinical Psychology, 61, 335-343.

Maton, K.I. (1989). Community settings as buffers of life stress? Highly supportive churches, mutual help groups, and senior centers. American Journal of Community Psychology, 17 (2), 203-232.

McLeod, J.D., \& Shanahan, M.J. (1996). Trajectories of poverty and children's mental health. Journal of Health and Social Behavior, 37, 207-220.

Menke, E.N. (2000). Comparison of the stressors and coping behaviors of homeless, previously homeless and never homeless poor children. Issues in Mental Health Nursing, 21, 691710.

Milevsky, A., \& Levitt, M.J. (2005). Sibling support in early adolescence: Buffering and compensation across relationships. European Journal of Developmental Psychology, 2(3), 299-320.

Miller, L. (1999). Treating post-traumatic stress disorder in children and families: Basic principles and clinical applications. American Journal of Family Therapy, 27 (1), 21-34.

Moskvina,V. Farmer, A., Swainson,V., O’Leary,J., Gunasinghe, C., Owen, N., McGuffin, P., \& Korsun, A. (2007). Interrelationship of childhood trauma, neuroticism and depressive phenotype. Depression and Anxiety, 24(3)

Muñoz, M., Vazquez, C., Bermejo, M., \& Vazquez, J.J. (1999). Stressful life events among homeless people: Quantity, types, timing and perceived causality. Journal of Community Psychology, 27, 73-90.

Nader, K.O. (1997). Assessing traumatic experiences in children. In T.M. Wilson and J. Pike, (Eds.), Assessing Psychological Trauma and PTSD. (pp 291-348) New York, NY: Guilford Press.

National Alliance to End Homelessness. (2007). Fact Checker: Family Homelessness. [Brochure].Washington, DC: Author. 
National Coalition for the Homeless (2007). Who is Homeless? NCH Facts \#3.[Brochure].Washington, DC:Author.

National Research Council (2002) From Neurons to Neighborhoods,

Nuñez, R. (1994). Hopes, Dreams \& Promise: The Future of Homeless Children in America. New York: Institute for Children and Poverty.

Racine, A.D., Joyce, T.J. \& Grossman, M. (1992) Effectiveness of health care services for pregnant women and children. The Future of Children, 2(2), 42-59.

Rafferty, Y., \& Shinn, M. (1991). The impact of homelessness on children. American Psychologist, 46, 1170-1179.

Rafferty, Y. (1995). The legal rights and educational problems of homeless children and youth. Educational Evaluation and Policy Analysis, 17 (1), 39-61.

Rayburn, N.R., Wenzel, S.L., Willott, M.N., Hambarsoomians, K., Marshall, G.N., \& Tucker, J.N. (2005). Trauma, depression, coping and mental health service seeking among impoverished women. Journal of Consulting and Clinical Psychology, 73 (4), 667-677.

Reyland, S.A., McMahon, T.J., Higgins-Delessandro, A., \& Luthar, S.S. (2002). Inner-city children living with a HIV-positive mother: Parent-child relationships, perception of social support, and psychological disturbance, Journal of Child and Family Studies, 11(3), 313-329.

Reichman, N.E., \& Teitler, J.O. (2003). Effects of psychosocial risk factors and perinatal interventions on birth weight: Evidence from New Jersey's HealthStart program. Perspectives on Sexual and Reproductive Health, 35(3), 130-137.

Rodriguez, N., Ryan, S.W., Van der Kemp, H., \& Foy, D.W. (1997). Posttraumatic stress disorder in adult female survivors of childhood sexual abuse: A comparison study. Journal of Consulting and Clinical Psychology, 65, 53-59.

Rogasch, F. \& Cicchetti, D. (2004). Child maltreatment and emergent personality organization: Perspectives from the 5 factor model. Journal of Abnormal Child Psychology, 32, 1-10.

Rutter, M. (1987). Psychosocial resilience and protective mechanisms. American Journal of Orthopsychiatry, 57(30), 16.

Orpinas, P., \& Frankowski, R. (2001). The aggression scale: A self report measure of aggressive behavior for young adolescents. Journal of Early Adolescence, 21 (1), 50-67.

Orpinas, P., Parcel, G.S., McAlister, A. \& Frankowski, R. (1995) Violence prevention in middle schools: A pilot evaluation. Journal of Adolescent Health, 17(6), 360-371. 
Overstreet, S., \& Dempsey, M (1999). Availability of family support as a moderator of exposure to community violence. Journal of Clinical Child psychology, 28 (2), 151-160.

Park, J.M., Metraux, S., Brodbar G., \& Cuhane, D.P. (2004). Child welfare involvement among children in homeless families. Child Welfare, 83, 423-437.

Penuel, W.R. \& Davey, T.L. (1999). "I don't like to live nowhere but here": The shelter as mediator of U.S. homeless youth's identity formation. Mind, Culture, \& Activity, 6, 222236.

Pepin, E.N. \& Banyard, V.L. (2006). Social support: A mediator between child maltreatment and developmental outcomes. Journal of Youth and Adolescence,35(4), 617-640.

Pettit, G.S., Bates, J.E., \& Dodge, K.E. (1997). Supportive parenting, ecological context, and children's adjustment: A seven-year longitudinal study. Child Development, 68, 908-923.

Pynoos, R.S., Steinberg, A.M., \& Piacentini, J,C. (1999). A developmental psychopathology model of childhood traumatic stress and intersection with anxiety disorders. Biological Psychiatry, 46, 1542-1554.

Sadowski, C.M., \& Friedrich, W.N. (2000). Psychometric properties of the trauma symptom checklist for children (TSCC) with psychiatrically hospitalized adolescents Child Maltreatment, 364-372.

Schumm, J.A., Stines, L.R., Hobfall, S.E., Jackson, A.P. (2005). The Double -barreled burden of child abuse and current stressful circumstances on adult women: The kindling of early traumatic experience. Journal of Traumatic Stress, 18(5), 467-476.

Self-Brown, S., LeBlanc, M., \& Kelley, M.L. (2004). Effects of violence exposure and daily stressors on psychological outcomes in urban adolescents. Journal of Traumatic Stress, 17 (6), 519-527.

Sheidow, A.J., Gorman-Smith, D., Tolan, P.H., \& Henry, D.B. (2001). Family and community characteristics: Risk factors for violence exposure in inner-city youth. Journal of Community Psychology, 29, 345-360.

Shinn, M. (2002). Homelessness: What is a psychologist to do? In T.A. Revenson, et al. (Eds.), A Quarter Century of Community Psychology: Readings from the American Journal of Community Psychology, (pp. 1-10). New York: Kluwer Academic/Plenum Publishers.

Shinn, M., Weitzman, B.C., Stojanovic, D., Knickman, J.R., Jimenez, L., Duchon L., James, S., et al. (1998). Predictors of homelessness among families in New York City: From shelter request to housing stability. American Journal of Public Health, 88 (11), 1561-1657.

Singh, G. K., \& Kogan, M.D. (2007).Persistent socioeconomic disparities in infant, neonatal and post neonatal mortality rates in the US: 1969-2001. Pediatrics, 119(4), 1-12. 
Slavin, L.A., \& Rainer, K.L. (1990). Gender differences in emotional support and depressive symptoms among adolescents: A prospective analysis. American Journal of Community Psychology, 18(3), 407-421.

Smith, N., \& Landreth, G. (2003). Intensive filial therapy with child witnesses of domestic violence: A comparison of individual and sibling group therapy. International Journal of Play Therapy, 12(1), 67-88.

Somer, E., \& Szwarcberg, S. (2001). Variables in delayed disclosure of childhood sexual abuse. American Journal of Orthopsychiatry, 71 (3), 1-10.

Stern, L., \& Nuñez, R. (1999). Homeless in America: A Children's Story. New York, NY: The Institute for Children and Poverty.

Stovall-McClough, K.C. \& Cloitre, M. (2006). Unresolved attachment, PTSD, and dissociation in women with childhood abuse histories. Journal of Consulting and Clinical Psychology, 74 (2), 219-228.

Street, A.E., Gibson, L.E., \& Holohan, D.R. (2005). Impact of childhood traumatic events, trauma-related guilt, and avoidant coping strategies on PTSD symptoms in female survivors of domestic violence. Journal of Traumatic Stress, 18(3), 245-252.

Sullivan, T.N., Kung, E.M. \& Farrell, A.D. (2004). Relation between witnessing violence and drug use initiation among rural adolescents: Parental monitoring and family support as protective factors. Journal of Clinical Child and Adolescent Psychology, 33, 488-498.

Szykula, S.A., Mas, C.H., Turner, C.W., Crowley, J., \& Sayger, T.V. (1991). Maternal social support and pro-social mother-child interactions. Journal of Family Psychology, 71 (3), $1-10$.

Tabachnick B.G. \& Fidell, L.S. (2001). Using Multivariate Statistics ( $4^{\text {th }}$ ed.). Needham, MA: Allyn \& Bacon.

U.S. Conference of Mayors. (2004). Hunger and homelessness survey: A status report on hunger and homelessness in America's cities. A 27-city survey. Retrieved October 1, 2005 from http://www.usmayors.org/uscm/hungersurvey/2004/onlinereport/HungerAndHomelessne ssReport2004.pdf.

U.S. Conference of Mayors. (2005). Hunger and homelessness survey: A status report on hunger and homelessness in America's cities. A 27-city survey. Retrieved October 1, 2007 from http://www.usmayors.org/uscm/hungersurvey/2005/onlinereport/HungerAndHomelessne ssReport2005.pdf.

U.S. Department of Health and Human Services. (2005). Child Maltreatment (Administration for Children and Families Publication). Rockville, MD: Author. 
U.S. Department of Health and Human Services. (2001). Report of the Surgeon General's Conference on Children's Mental Health. Rockville, MD: Author.

U.S. Department of Health and Human Services. (1999). Mental Health: A Report of the Surgeon General. Rockville, MD: Author.

Van der Kolk, B., B.A., Roth, S., Pelcovitz, D., Sunday, S., \& Spinazzola, J. (2005). Disorders of extreme stress: The empirical foundation of a complex adaptation to trauma. Journal of Traumatic Stress, 18(5), 389-399.

Vinokur, A.D., Price, R.H., \& Caplan, R.D. (1996). Hard times and hurtful partners: how financial strain affects depression and relationship satisfaction of unemployed persons and their spouses. Journal of Personality and Social Psychology, 71, 166-179.

Weinreb, L.F., Buckner, J.C., Williams, V., \& Nicholson, J. (2006). A comparison of the health and mental health sttus of homelss mothers in Worcester MA: 1993 and 2003. American Journal of Public Health, 96(8), 1444-1448.

Whipple, E.E. (2006). Child abuse and neglect: Consequences of physical, sexual and emotional abuse of children. In H.E. Fitzgerald, E. Hiram, \& B.M. Lester (Eds.), The crisis in youth mental health, critical issues and effective program. Vol 1: Childhood disorders (pp. 205229). Westport CT: US. Praeger Publishers/Greenwood Publishing Group.

Wills, T.A. \& Cleary, S.D. (1996). How are social support effects mediated?A test with parental supports and adolescent substance use. Journal of Personality and Social Psychology, 937-952.

Windom, C.S. (1999). Posttraumatic stress disorder in abused and neglected children grown up. American Journal of Psychiatry, 156, 1223-1229.

Yamaguchi, B. J., Strawser, S., \& Higgins, K. (1997). Children who are homeless: Implications for educators. Intervention in School and Clinic, 33, 90-97.

Zima, B.T., Bussing, R., Bystritsky, M., Widawski, M.H., Belin, T.R., \& Benjamin, B. (1999). Psychosocial stressors among sheltered homeless children: Relationship to behavior problems and depressive symptoms. American Journal of Orthopsychiatry, 69, 127-133.

Zima, B.T., Wells, K.B., \& Freeman, H.E. (1994). Emotional and behavioral problems and severe academic delays among sheltered homeless children in Los Angeles County. American Journal of Public Health, 84, 260-264.

Zinkus, P.W. \& Gottlieb, M.I. (1979). Patterns of perceptual deficits in academically deficient juvenile delinquents. Psychology in the Schools, 16 (1), 19-27. 


\begin{abstract}
APPENDIX A
Georgia State University

Department of Psychology

Informed Consent: Trauma Exposure and Behavioral Outcomes in Sheltered Homeless Children

Parent Consent Form

Principal Investigators:

Gabriel Kuperminc, Ph.D. and Gregory Jurkovic, Ph.D.

Student Principal Investigator:

Beryl Ann Cowan, J.D., M.A.
\end{abstract}

Dear Parent,

\title{
Purpose and Procedures
}

You and your child are being asked to take part in a research study. We want to learn more about the difficult experiences that homeless families have and how this affects children. Parents and children will be asked about things that happened to them before and after they became homeless. Parents will also be asked some questions about their child's behavior now. Children will be asked about some things that they might be feeling and doing. We also want to learn what helps homeless children feel good. We are going to ask children about their special feelings for their moms or dads, their sisters and brothers and their friends. Answering these questions will take parents about 30 minutes, and will take children about 45 minutes.

\section{Voluntary Participation and Withdrawal}

No one has to take part in this study. If you do not want to participate in the study, nothing bad will happen to you. You and your child can decide not to answer a question, or to skip some questions. If you decide to be in the study and then change your mind, you can stop answering questions and nothing bad will happen to you or your child.

If you decide to be part of this study, you will only meet with us one time. We will ask you questions in a private room where no-one else can listen to your answers. The answers that you give us will only be used in our research, and will not be talked about with anyone. The answers to our questions will be written down on pieces of paper that do not have your name or your child's name on it. No one will be able to know who you are or what you said, and the information will be kept in locked files at Georgia State University. Only our research staff will be able to look at this information.

\section{Risks}

Most parents who answer the types of questions that are asked in our study are not likely to feel uncomfortable. There is a risk that some parents might feel uncomfortable talking about the number of times that they have been homeless, or events that happened that led to homelessness. Some children who answer questions may feel uncomfortable talking about hard things that happened to them, or how they are feeling or behaving now. This does not usually 
happen. If you allow your child to be a part of our study, and she or he starts to act upset or worried, we will stop asking questions immediately. We will talk to you, and let you know that your child is upset and we will give you the name of a mental health center where you can take your child for treatment at no cost to you. In very rare circumstances, if your child becomes extremely upset, and is threatening to hurt him or herself, we will call a licensed psychologist immediately to come to the shelter to interview your child at no cost.

\section{Confidentiality}

Any information that you or your child tells us is private except in three situations. If your child tells us that he or she is presently being abused by someone, we are will report this information to DFCAS. If your child tells us that she or he is going to hurt someone else this will be reported to your facility director. Finally, if your child tells us that he or she is planning kill herself or himself, we will immediately call a licensed psychologist to come to the clinic.

\section{Contact Information}

Call Dr. Gabriel Kuperminc at (404) 651-0763 or Dr. Gregory Jurkovic at (404) 6512859 or Beryl Ann Cowan (678)-592-6368 if your have any questions about this study. If you have any questions or concerns about your rights as a participant in this research study, you may call the Institutional Review Board (IRB) which oversees the protection of human research participants. Susan Vogtner can be reached at (404) 463-0674. Pleases complete the enclosed research form as soon as possible. We will give you a copy of this consent form to keep.

Print Your Name:

Print Your Child's name:

Please check one option below:

I have read this consent form and I will participate in the study and I allow my child to take part in the study.

I have read this consent form and I will not take part in the study and I do not allow my child to take part in the study.

Parent/Guardian Signature: Date:

Researcher Printed Name: Date: 


\section{APPENDIX B}

Parent

Interview

We are trying to learn about experiences of homeless parents and their children in order to help other families. Please answer these questions the best you can. There are no right or wrong answers. This information will only be used for research purposes and will not be shared with your shelter staff. This interview should last no longer than 10 minutes.

Thanks for your time.

1. How old are you?

2. Are you: married?

separated?

divorced?

single?

Partnered?

3. How old were you when you first became homeless?

4. Were you in foster care when you were a child?

yes no

5. Were you homeless when you were a child?

yes

no

6. What are the ages of your children?

\begin{tabular}{lrr} 
child $\# 1$ & age & gender \\
child $\# 2$ & age & gender \\
\cline { 2 - 3 } child $\# 3$ & age & gender \\
child $\# 4$ & age & gender \\
child $\# 5$ & age & gender
\end{tabular}

7. What is your race or cultural background?

African American

Caribbean

African

White

Latino/Latina

Biracial

Asian/Pacific Islander

Other 
8. What are the races or cultural backgrounds of your children?

African American

Caribbean

African

Latino/Latina

Biracial

Asian/Pacific Islander

Other

9. Do all of your children live with you at the shelter?

yes

no

10. Are any of your children who are not living with you presently staying with your relatives or friends?

yes

no

11 Are any of your children who are not living with you presently in foster care?

yes

no

12. In the past did you ever have children living away from you with relatives or friends?

yes__ no

13. In the past did you ever have children who were in foster care?

yes

no

14. How old were each of your children when they first became homeless?

child \#1 child \#2

child\#3 age when first homeless

child \#4_age when first homeless

child $\# 5$ age when first homeless

15. Over the past year, how many months or weeks have you lived in a shelter with your children?

16. Before this most recent time, how many times have you been homeless?

17. Before you were most recently homeless (past twelve months) where did you live?

An apartment

I owned a condo

A rented house

I owned a house 
With friends

With family

18. Before you were most recently homeless, who did you live with?

(check all that apply)

alone

all of my kids

some of my kids

friends

family members

my boyfriend

my husband

19. What are some of the reasons that you became homeless? (check all that apply)

You were getting physically abused by your husband or boyfriend

You were getting emotionally abused by your husband or boyfriend

There were too many people staying where you were living

You got evicted by the landlord

You lost your job and didn't have money for rent

You lost you job and didn't have money for your mortgage

You moved to a new city or town

You lost your benefits

Your house was destroyed by a fire, flood or hurricane

Your house was run down and not fit or healthy to live in

You weren't getting along with friends or family that you were living with

20. How many different places have you and your children lived in the past year?

21. In the past year, how many schools have your children gone to?

22. Has your child's behavior changed since you became homeless?

Yes

No

Research staff are to insert the word program/facility for shelter where appropriate. 


\section{APPENDIX C}

PARENT FORM

Child's Name

Date

Your Name

Mark how well each item describes your child in the past week. (circle the number)

Don't skip any, even if you're not sure.

\begin{tabular}{|c|c|c|c|}
\hline $\begin{array}{l}\text { Not True } \\
\text { or } \\
\text { Rarely } \\
\text { True }\end{array}$ & $\begin{array}{l}\text { Somewhat } \\
\text { or } \\
\text { Sometimes } \\
\text { True } \\
\end{array}$ & $\begin{array}{l}\text { Very True } \\
\text { or } \\
\text { Often } \\
\text { True } \\
\end{array}$ & \\
\hline 0 & 1 & 2 & Difficulty concentrating \\
\hline 0 & 1 & 2 & Mood swings \\
\hline 0 & 1 & 2 & Thinks of bad memories \\
\hline 0 & 1 & 2 & Spaces out \\
\hline 0 & 1 & 2 & Feels too guilty \\
\hline 0 & 1 & 2 & Anxious \\
\hline 0 & 1 & 2 & Irrational fears \\
\hline 0 & 1 & 2 & Repeats the same game or activity \\
\hline 0 & 1 & 2 & Clings to adults \\
\hline 0 & 1 & 2 & Avoids former interests \\
\hline 0 & 1 & 2 & Fights \\
\hline 0 & 1 & 2 & Bossy with peers \\
\hline 0 & 1 & 2 & Sad or depressed \\
\hline 0 & 1 & 2 & Hyper-alert \\
\hline 0 & 1 & 2 & Feels picked on \\
\hline 0 & 1 & 2 & Gets in trouble \\
\hline 0 & 1 & 2 & Worries \\
\hline 0 & 1 & 2 & Fearful \\
\hline 0 & 1 & 2 & Withdrawn \\
\hline 0 & 1 & 2 & Nervous \\
\hline 0 & 1 & 2 & Startles easily \\
\hline 0 & 1 & 2 & Irritable \\
\hline 0 & 1 & 2 & Quick temper \\
\hline 0 & 1 & 2 & Argues \\
\hline 0 & 1 & 2 & Secretive \\
\hline 0 & 1 & 2 & Doesn't care anymore \\
\hline
\end{tabular}


0

0

0

0

0

0
1

1

1

1

1

1
2

2

2

2

2

2

PROPS 1.2xr @ Ricky Greenwald, 1997
Difficulty sleeping

Nightmares or bad dreams

Wets bed

Eating problems

Stomach aches

Headaches 
Hello Parents:

\section{APPENDIX D}

Thank you for letting your child talk to us. Sometimes kids feel upset after talking about hard things that have happened to them, and they might need some extra help or attention.

Here are some things to watch out for:

1. Lots of crying for no reason.

2. Acting really angry for no reason, hitting, having tantrums or "falling out."

3. Having bad nightmares.

4. Wetting the bed after being potty trained.

5. Saying that they want to die or hurt themselves, or kill someone else.

If any of these things a re happening with your child please get help for him or her. You can talk to someone at your shelter, or you can call Beryl Ann Cowan 678-592-6368. We can give you the name of someone who can help your child.

Thank you. 


\section{APPENDIX E \\ Youth Assent Form}

Hello:

We want to learn about kids like you who live in shelters and transitional programs. We want to learn about things that might have happened to you before and after you came to live here. Also, we want to know how you are feeling and acting now. We would like to know what makes you feel good and your special times with your mom or dad, your brother or sister, or a best friend. It will take about 45 minutes to talk to us.

You do not have to answer the questions if you don't want to. It is totally up to you. Nothing bad will happen to kids who don't want to be part of our study. If you do answer some questions and then change your mind, you can stop at any time. Nothing bad will happen to you or your family.

Usually when we ask kids questions, they feel fine. But sometimes, kids feel upset talking about hard times. If a question makes you feel upset or sad, you can stop at any time. When kids feel very sad after talking to us, we help them by finding a grown up whose job it is to listen to their feelings.

Anything that you tell us is private. We will not tell anyone about what you have shared with us, unless you tell us that someone is hurting you or touching you in a bad way, or that you plan to hurt yourself or hurt another person. If this happens, we will only tell this information to doctors or other special grown-ups who will be able to help you because it is our job to help kids who might be in danger.

Learning about your feelings might help other kids who become homeless. Thank you for learning about our study. You may ask us any questions at any time. If you would like to be a part of our study, please print your name below.

Name

Date

Research staff

Date 


\section{APPENDIX F}

\section{Child Interview}

Can we ask you some questions about yourself? This information is totally private. There are no right or wrong answers.

1. How old are you?

2. Race ( research staff shall fill in this answer based on information provided from parent not visual observation)

3. Who lives with you at the shelter?

4. Do you have any brothers or sisters who don't live with you here?

5. What grade are you in?

6. How many schools have you gone to this grade/year?

7. How long have you been at this shelter?

8. Have you lived at any other shelters?

9. How did you live with before you came here?

\section{INSTRUCTIONS FOR SCORING NETWORK OF RELATIONSHIP INVENTORY}

The first two pages of the Network of Relationships Inventory are used to identify the people who will be rated on the questionnaire. We include an option for an extra person, such as a step-parent. You may also choose to select different relationships. If you wish, you can restrict friendships or romantic relationships to current ones.

The most common version of the NRI consists of ten sets of scales. The names of the scales and item compositions go as follows:

$\begin{array}{llll}\text { Companionship: } & \text { Items } 9, & 19, & 29 \\ \text { Conflict: } & \text { Items } 10, & 20, & 30 \\ \text { Instrumental Aid: } & \text { Items } 11, & 21, & 31 \\ \text { Antagonism: } & \text { Items } 12, & 22, & 32 \\ \text { Intimacy: } & \text { Items 13, 23, } & 33 \\ \text { Nurturance: } & \text { Items 14, 24, } & 34 \\ \text { Affection: } & \text { Items } 15,25, & 35 \\ \text { Admiration: } & \text { Items 16, 26, } & 36 \\ \text { Relative Power: } & \text { Items 17, 27, } & 37 \\ \text { Reliable Alliance: } & \text { Items } 18, & 28, & 38\end{array}$


In our most recent version, we also are using the following three scales:

\section{Support}

1. How often do you turn to this person for support with personal problems?

2. How often do you depend on this person for help, advice, or sympathy?

3. When you are feeling down or upset, how often do you depend on this person to cheer things up?

\section{Criticism}

1. How often does this person point out your faults or put you down?

2. How often does this person criticize you?

3. How often does this person say mean or harsh things to you?

\section{Dominance}

1. How often does this person get his/her way when you two do not agree about what to do?

2. How often does this person end up being the one who makes the decisions for both of you?

3. How does this person get you to do things his/her way? 
You may also consider using any of the following scales that were on earlier versions.

\section{Satisfaction}

1. How satisfied are you with your relationship with this person?

2. How good is your relationship with this person?

3. How happy are you with the way things are between you and this person?

1. How much does this person punish you?

Punishment

2. How much does this person discipline you for disobeying him/her?

3. How much does this person scold you for doing something you are not supposed to do?

Scale scores are derived by simple averaging of three items. If the subjects are missing a specific item, scale scores can be derived from the other two items. I do not recommend that scale scores be derived if only one item of the three is completed.

We usually derive factors of social support and negative interchanges for each relationship. The social support measure would consist of the average of the Companionship, Instrumental Aid, Intimacy, Nurturance, Affection, Admiration, and Reliable Alliance scores. If included, Satisfaction and Support would also go on this factor. The negative interaction factor is the average of the Conflict and Antagonism scales. If included, Criticism, Dominance, and Punishment would go on this factor. Power is not part of these factors. Separate scores are derived for each relationship.

We have also used a short form assessing support with items $16,18,19,21,23,25$, and 34 and negative interaction with items $10,12,20,22,30$, and 32 . If you do this, you can only measure the factors, not the scales.

It is perfectly acceptable to us for you to include only a limited number of relationships or scales. However, we request that you include all three items for any scale that you incorporate so as to insure comparability of results across studies. Validational information can be obtained from the articles using the measure. A summary of some evidence is presented in "Furman, W. (1996). The measurement of children and adolescents' perceptions of friendships: Conceptual and methodological issues. In W. M. Bukowski, A. F. Newcomb, \& W. W. Hartup (Eds.), The company they keep: Friendships in childhood and adolescence. Cambridge, MA: Cambridge University Press."

(C) Copyright: W. Furman, Relationship Center, Department of Psychology, University of Denver, Denver, Colorado 80208 . 


\section{APPENDIX G}

Everyone has a number of people who are important in his or her life. These questions ask about your relationships with each of the following people: your mother, your father, a sibling, a relative, a grandparent, a same-sex friend, and an opposite-sex friend.

The first questions ask you to identify your mother figure, your father figure, a sibling, a relative, a grandparent, and two friends about whom you will be answering the questions.

1. Circle the mother figure you will be describing. (If you have both, choose the one you think of as your primary mother figure.)
A. Biological/Adopted Mother
B. Step-Mother (or Father's Significant Other)
C. Other

2. Circle the father figure you will be describing. (If you have both, choose the one you think of as your primary father figure.)
A. Biological/Adopted Father
B. Step-Father (or Mother's Significant Other)
C. Other

3. If one of your brothers or sisters is participating in this study also, please choose him or her. If you do not have a sibling taking part in this study, please describe your relationship with the sibling you consider to be most important/closest to you. (If several are equally important/close, just select one.) If you do not have a sibling, leave these questions blank.

Your Sibling's First Name

How old is s/he? years old.

4. Now we would like you to choose a relative who is/was most important to you. Is this person a a) grandmother, b) grandfather, c) aunt, or d) uncle? (Please circle one.) The relative's first name is

5. Now we would like you to choose a boy/girl friend whom you are dating or dated. You may choose someone you are seeing now, or someone you went out with earlier in high school. If you choose a past boy/girl friend, please answer the questions as you would have when you were in the relationship.

\section{Boy/Girl Friend's First Name}

How long is/was the relationship? years months (please fill in numbers)
Are you seeing this person now?
A. Yes
B. No 
6. Please choose the most important same-sex friend you have had in high school. You may select someone who is your most important same-sex friend now, or who was your most important same-sex friend earlier in high school. Do not choose a sibling. If you select a person with whom you are no longer friends, please answer the questions as you would have when you were in the relationship.

Same-Sex Friend's First Name

How long is/was the friendship? years months (please fill in numbers)

Are you close friends now?
A. Yes
B. Friends, but not as close as before
C. No

7. Please choose the most important other-sex friend you have had in high school. You may select someone who is your most important other-sex friend now, or who was your most important other-sex friend earlier in high school. Do not choose a sibling, relative, or boy/girl friend-even if she or he is or was your best friend. If you select a person with whom you are no longer friends, just answer the questions as you would have when you were in the relationship.

Other-Sex Friend's First Name

How long is/was the friendship? years months (please fill in numbers)

Are you close friends now?
A. Yes
B. Friends, but not as close as before
C. No

8. Sometimes we would also like you to answer the following questions about some extra person. If there is a name written in the space below, please answer about this person also.

Extra Person

Relationship

Now we would like you to answer the following questions about the people you have selected above. Sometimes the answers for different people may be the same but sometimes they may be different.

9. How much free time do you spend with this person?

\begin{tabular}{lccccc||cccccc} 
& $\begin{array}{c}\text { Little } \\
\text { or } \\
\text { None }\end{array}$ & $\begin{array}{c}\text { Some- } \\
\text { what }\end{array}$ & $\begin{array}{c}\text { Very } \\
\text { Much }\end{array}$ & $\begin{array}{c}\text { Extre- } \\
\text { mely } \\
\text { Much }\end{array}$ & $\begin{array}{c}\text { The } \\
\text { Most }\end{array}$ & $\begin{array}{c}\text { Little } \\
\text { or } \\
\text { None }\end{array}$ & $\begin{array}{c}\text { Some- } \\
\text { what }\end{array}$ & $\begin{array}{c}\text { Very } \\
\text { Much }\end{array}$ & $\begin{array}{c}\text { Extre- } \\
\text { mely } \\
\text { Much }\end{array}$ & $\begin{array}{c}\text { The } \\
\text { Most }\end{array}$ & \\
Mother & 1 & 2 & 3 & 4 & 5 & 1 & 2 & 3 & 4 & 5 & Boy/Girl Friend \\
Father & 1 & 2 & 3 & 4 & 5 & 1 & 2 & 3 & 4 & 5 & Same-Sex Friend \\
Sibling & 1 & 2 & 3 & 4 & 5 & 1 & 2 & 3 & 4 & 5 & Other-Sex Friend \\
Relative & 1 & 2 & 3 & 4 & 5 & 1 & 2 & 3 & 4 & 5 & Extra Person \\
\hline
\end{tabular}


10. How much do you and this person get upset with or mad at each other?

\begin{tabular}{|c|c|c|c|c|c|c|c|c|c|c|c|}
\hline & $\begin{array}{l}\text { Little } \\
\text { or } \\
\text { None }\end{array}$ & $\begin{array}{l}\text { Some- } \\
\text { what }\end{array}$ & $\begin{array}{l}\text { Very } \\
\text { Much }\end{array}$ & $\begin{array}{l}\text { Extre- } \\
\text { mely } \\
\text { Much }\end{array}$ & $\begin{array}{l}\text { The } \\
\text { Most }\end{array}$ & $\begin{array}{l}\text { Little } \\
\text { or } \\
\text { None }\end{array}$ & $\begin{array}{l}\text { Some- } \\
\text { what }\end{array}$ & $\begin{array}{l}\text { Very } \\
\text { Much }\end{array}$ & $\begin{array}{l}\text { Extre- } \\
\text { mely } \\
\text { Much }\end{array}$ & $\begin{array}{l}\text { The } \\
\text { Most }\end{array}$ & \\
\hline Mother & 1 & 2 & 3 & 4 & 5 & 1 & 2 & 3 & 4 & 5 & Boy/Girl Friend \\
\hline Father & 1 & 2 & 3 & 4 & 5 & 1 & 2 & 3 & 4 & 5 & Same-Sex Friend \\
\hline Sibling & 1 & 2 & 3 & 4 & 5 & 1 & 2 & 3 & 4 & 5 & Other-Sex Friend \\
\hline Relative & 1 & 2 & 3 & 4 & 5 & 1 & 2 & 3 & 4 & 5 & Extra Person \\
\hline
\end{tabular}

11. How much does this person teach you how to do things that you don't know?

\begin{tabular}{|c|c|c|c|c|c|c|c|c|c|c|c|}
\hline & $\begin{array}{l}\text { Little } \\
\text { or } \\
\text { None }\end{array}$ & $\begin{array}{l}\text { Some- } \\
\text { what }\end{array}$ & $\begin{array}{l}\text { Very } \\
\text { Much }\end{array}$ & $\begin{array}{l}\text { Extre- } \\
\text { mely } \\
\text { Much }\end{array}$ & $\begin{array}{l}\text { The } \\
\text { Most }\end{array}$ & $\begin{array}{l}\text { Little } \\
\text { or } \\
\text { None }\end{array}$ & $\begin{array}{l}\text { Some- } \\
\text { what }\end{array}$ & $\begin{array}{l}\text { Very } \\
\text { Much }\end{array}$ & $\begin{array}{l}\text { Extre- } \\
\text { mely } \\
\text { Much }\end{array}$ & $\begin{array}{l}\text { The } \\
\text { Most }\end{array}$ & \\
\hline Mother & 1 & 2 & 3 & 4 & 5 & 1 & 2 & 3 & 4 & 5 & Boy/Girl Friend \\
\hline Father & 1 & 2 & 3 & 4 & 5 & 1 & 2 & 3 & 4 & 5 & Same-Sex Friend \\
\hline Sibling & 1 & 2 & 3 & 4 & 5 & 1 & 2 & 3 & 4 & 5 & Other-Sex Friend \\
\hline Relative & 1 & 2 & 3 & 4 & 5 & 1 & 2 & 3 & 4 & 5 & Extra Person \\
\hline
\end{tabular}

12. How much do you and this person get on each other's nerves?

\begin{tabular}{|c|c|c|c|c|c|c|c|c|c|c|c|}
\hline & $\begin{array}{l}\text { Little } \\
\text { or } \\
\text { None }\end{array}$ & $\begin{array}{l}\text { Some- } \\
\text { what }\end{array}$ & $\begin{array}{l}\text { Very } \\
\text { Much }\end{array}$ & $\begin{array}{l}\text { Extre- } \\
\text { mely } \\
\text { Much }\end{array}$ & $\begin{array}{l}\text { The } \\
\text { Most }\end{array}$ & $\begin{array}{l}\text { Little } \\
\text { or } \\
\text { None }\end{array}$ & $\begin{array}{l}\text { Some- } \\
\text { what }\end{array}$ & $\begin{array}{l}\text { Very } \\
\text { Much }\end{array}$ & $\begin{array}{l}\text { Extre- } \\
\text { mely } \\
\text { Much }\end{array}$ & $\begin{array}{l}\text { The } \\
\text { Most }\end{array}$ & \\
\hline Mother & 1 & 2 & 3 & 4 & 5 & 1 & 2 & 3 & 4 & 5 & Boy/Girl Friend \\
\hline Father & 1 & 2 & 3 & 4 & 5 & 1 & 2 & 3 & 4 & 5 & Same-Sex Friend \\
\hline Sibling & 1 & 2 & 3 & 4 & 5 & 1 & 2 & 3 & 4 & 5 & Other-Sex Friend \\
\hline Relative & 1 & 2 & 3 & 4 & 5 & 1 & 2 & 3 & 4 & 5 & Extra Person \\
\hline
\end{tabular}

13. How much do you talk about everything with this person?

\begin{tabular}{lccccc||cccccc} 
& $\begin{array}{c}\text { Little } \\
\text { or } \\
\text { None }\end{array}$ & $\begin{array}{l}\text { Some- } \\
\text { what }\end{array}$ & $\begin{array}{c}\text { Very } \\
\text { Much }\end{array}$ & $\begin{array}{c}\text { Extre- } \\
\text { mely } \\
\text { Much }\end{array}$ & $\begin{array}{c}\text { The } \\
\text { Most }\end{array}$ & $\begin{array}{c}\text { Little } \\
\text { or } \\
\text { None }\end{array}$ & $\begin{array}{c}\text { Some- } \\
\text { what }\end{array}$ & $\begin{array}{c}\text { Very } \\
\text { Much }\end{array}$ & $\begin{array}{c}\text { Extre- } \\
\text { mely } \\
\text { Much }\end{array}$ & $\begin{array}{c}\text { The } \\
\text { Most }\end{array}$ & \\
Mother & 1 & 2 & 3 & 4 & 5 & 1 & 2 & 3 & 4 & 5 & Boy/Girl Friend \\
Father & 1 & 2 & 3 & 4 & 5 & 1 & 2 & 3 & 4 & 5 & Same-Sex Friend \\
Sibling & 1 & 2 & 3 & 4 & 5 & 1 & 2 & 3 & 4 & 5 & Other-Sex Friend \\
Relative & 1 & 2 & 3 & 4 & 5 & 1 & 2 & 3 & 4 & 5 & Extra Person \\
& & & & & & & & & & &
\end{tabular}


14. How much do you help this person with things she/he can't do by her/himself?

\begin{tabular}{lccccc||cccccc} 
& $\begin{array}{c}\text { Little } \\
\text { or } \\
\text { None }\end{array}$ & $\begin{array}{c}\text { Some- } \\
\text { what }\end{array}$ & $\begin{array}{c}\text { Very } \\
\text { Much }\end{array}$ & $\begin{array}{c}\text { Extre- } \\
\text { mely } \\
\text { Much }\end{array}$ & $\begin{array}{c}\text { The } \\
\text { Most }\end{array}$ & $\begin{array}{c}\text { Little } \\
\text { or } \\
\text { None }\end{array}$ & $\begin{array}{c}\text { Some- } \\
\text { what }\end{array}$ & $\begin{array}{c}\text { Very } \\
\text { Much }\end{array}$ & $\begin{array}{c}\text { Extre- } \\
\text { mely } \\
\text { Much }\end{array}$ & $\begin{array}{c}\text { The } \\
\text { Most }\end{array}$ & \\
Mother & 1 & 2 & 3 & 4 & 5 & 1 & 2 & 3 & 4 & 5 & Boy/Girl Friend \\
Father & 1 & 2 & 3 & 4 & 5 & 1 & 2 & 3 & 4 & 5 & Same-Sex Friend \\
Sibling & 1 & 2 & 3 & 4 & 5 & 1 & 2 & 3 & 4 & 5 & Other-Sex Friend \\
Relative & 1 & 2 & 3 & 4 & 5 & 1 & 2 & 3 & 4 & 5 & Extra Person \\
\hline
\end{tabular}

15. How much does this person like or love you?

\begin{tabular}{lccccc||cccccc} 
& $\begin{array}{c}\text { Little } \\
\text { or } \\
\text { None }\end{array}$ & $\begin{array}{c}\text { Some- } \\
\text { what }\end{array}$ & $\begin{array}{c}\text { Very } \\
\text { Much }\end{array}$ & $\begin{array}{c}\text { Extre- } \\
\text { mely } \\
\text { Much }\end{array}$ & $\begin{array}{c}\text { The } \\
\text { Most }\end{array}$ & $\begin{array}{c}\text { Little } \\
\text { or } \\
\text { None }\end{array}$ & $\begin{array}{c}\text { Some- } \\
\text { what }\end{array}$ & $\begin{array}{c}\text { Very } \\
\text { Much }\end{array}$ & $\begin{array}{c}\text { Extre- } \\
\text { mely } \\
\text { Much }\end{array}$ & $\begin{array}{c}\text { The } \\
\text { Most }\end{array}$ & \\
Mother & 1 & 2 & 3 & 4 & 5 & 1 & 2 & 3 & 4 & 5 & Boy/Girl Friend \\
Father & 1 & 2 & 3 & 4 & 5 & 1 & 2 & 3 & 4 & 5 & Same-Sex Friend \\
Sibling & 1 & 2 & 3 & 4 & 5 & 1 & 2 & 3 & 4 & 5 & Other-Sex Friend \\
Relative & 1 & 2 & 3 & 4 & 5 & 1 & 2 & 3 & 4 & 5 & Extra Person \\
\hline
\end{tabular}

16. How much does this person treat you like you're admired and respected?

\begin{tabular}{|c|c|c|c|c|c|c|c|c|c|c|c|}
\hline & $\begin{array}{l}\text { Little } \\
\text { or } \\
\text { None }\end{array}$ & $\begin{array}{l}\text { Some- } \\
\text { what }\end{array}$ & $\begin{array}{l}\text { Very } \\
\text { Much }\end{array}$ & $\begin{array}{l}\text { Extre- } \\
\text { mely } \\
\text { Much }\end{array}$ & $\begin{array}{l}\text { The } \\
\text { Most }\end{array}$ & $\begin{array}{l}\text { Little } \\
\text { or } \\
\text { None }\end{array}$ & $\begin{array}{l}\text { Some- } \\
\text { what }\end{array}$ & $\begin{array}{l}\text { Very } \\
\text { Much }\end{array}$ & $\begin{array}{l}\text { Extre- } \\
\text { mely } \\
\text { Much }\end{array}$ & $\begin{array}{l}\text { The } \\
\text { Most }\end{array}$ & \\
\hline Mother & 1 & 2 & 3 & 4 & 5 & 1 & 2 & 3 & 4 & 5 & Boy/Girl Friend \\
\hline Father & 1 & 2 & 3 & 4 & 5 & 1 & 2 & 3 & 4 & 5 & Same-Sex Friend \\
\hline Sibling & 1 & 2 & 3 & 4 & 5 & 1 & 2 & 3 & 4 & 5 & Other-Sex Friend \\
\hline Relative & 1 & 2 & 3 & 4 & 5 & 1 & 2 & 3 & 4 & 5 & Extra Person \\
\hline 17. Who te & $\begin{array}{l}\mathrm{r} \text { pers } \\
\text { S/he } \\
\text { always } \\
\text { does }\end{array}$ & $\begin{array}{l}\text { n what } \\
\text { S/he } \\
\text { often } \\
\text { does }\end{array}$ & $\begin{array}{l}\text { o do } \\
\text { About } \\
\text { the } \\
\text { same }\end{array}$ & $\begin{array}{l}\text { ore oft } \\
\text { I often } \\
\text { do }\end{array}$ & $\begin{array}{c}\mathrm{n}, \text { you } \\
\text { I } \\
\text { always } \\
\text { do }\end{array}$ & $\begin{array}{l}\text { or this } \\
\text { S/he } \\
\text { always } \\
\text { does }\end{array}$ & $\begin{array}{l}\text { Derson } \\
\text { S/he } \\
\text { often } \\
\text { does }\end{array}$ & $\begin{array}{l}\text { About } \\
\text { the } \\
\text { same }\end{array}$ & $\begin{array}{l}\text { I often } \\
\text { do }\end{array}$ & $\begin{array}{c}\text { I } \\
\text { always } \\
\text { do }\end{array}$ & \\
\hline Mother & 1 & 2 & 3 & 4 & 5 & 1 & 2 & 3 & 4 & 5 & Boy/Girl Friend \\
\hline Father & 1 & 2 & 3 & 4 & 5 & 1 & 2 & 3 & 4 & 5 & Same-Sex Friend \\
\hline Sibling & 1 & 2 & 3 & 4 & 5 & 1 & 2 & 3 & 4 & 5 & Other-Sex Friend \\
\hline Relative & 1 & 2 & 3 & 4 & 5 & 1 & 2 & 3 & 4 & 5 & Extra Person \\
\hline
\end{tabular}


18. How sure are you that this relationship will last no matter what?

\begin{tabular}{|c|c|c|c|c|c|c|c|c|c|c|c|}
\hline & $\begin{array}{l}\text { Little } \\
\text { or } \\
\text { None }\end{array}$ & $\begin{array}{l}\text { Some- } \\
\text { what }\end{array}$ & $\begin{array}{l}\text { Very } \\
\text { Much }\end{array}$ & $\begin{array}{l}\text { Extre- } \\
\text { mely } \\
\text { Much }\end{array}$ & $\begin{array}{l}\text { The } \\
\text { Most }\end{array}$ & $\begin{array}{l}\text { Little } \\
\text { or } \\
\text { None }\end{array}$ & $\begin{array}{l}\text { Some- } \\
\text { what }\end{array}$ & $\begin{array}{l}\text { Very } \\
\text { Much }\end{array}$ & $\begin{array}{l}\text { Extre- } \\
\text { mely } \\
\text { Much }\end{array}$ & $\begin{array}{l}\text { The } \\
\text { Most }\end{array}$ & \\
\hline Mother & 1 & 2 & 3 & 4 & 5 & 1 & 2 & 3 & 4 & 5 & Boy/Girl Friend \\
\hline Father & 1 & 2 & 3 & 4 & 5 & 1 & 2 & 3 & 4 & 5 & Same-Sex Friend \\
\hline Sibling & 1 & 2 & 3 & 4 & 5 & 1 & 2 & 3 & 4 & 5 & Other-Sex Friend \\
\hline Relative & 1 & 2 & 3 & 4 & 5 & 1 & 2 & 3 & 4 & 5 & Extra Person \\
\hline 19. How $n$ & $\begin{array}{c}\text { play } \\
\text { Little } \\
\text { or } \\
\text { None }\end{array}$ & $\begin{array}{l}\text { round } \\
\text { Some- } \\
\text { what }\end{array}$ & $\begin{array}{l}\text { nd ha } \\
\text { Very } \\
\text { Much }\end{array}$ & $\begin{array}{l}\text { fun } \\
\text { Extre- } \\
\text { mely } \\
\text { Much }\end{array}$ & $\begin{array}{l}\text { th this } \\
\text { The } \\
\text { Most }\end{array}$ & $\begin{array}{l}\text { erson } \\
\text { Little } \\
\text { or } \\
\text { None }\end{array}$ & $\begin{array}{l}\text { Some- } \\
\text { what }\end{array}$ & $\begin{array}{l}\text { Very } \\
\text { Much }\end{array}$ & $\begin{array}{l}\text { Extre- } \\
\text { mely } \\
\text { Much }\end{array}$ & $\begin{array}{l}\text { The } \\
\text { Most }\end{array}$ & \\
\hline Mother & 1 & 2 & 3 & 4 & 5 & 1 & 2 & 3 & 4 & 5 & Boy/Girl Friend \\
\hline Father & 1 & 2 & 3 & 4 & 5 & 1 & 2 & 3 & 4 & 5 & Same-Sex Friend \\
\hline Sibling & 1 & 2 & 3 & 4 & 5 & 1 & 2 & 3 & 4 & 5 & Other-Sex Friend \\
\hline Relative & 1 & 2 & 3 & 4 & 5 & 1 & 2 & 3 & 4 & 5 & Extra Person \\
\hline
\end{tabular}

20. How much do you and this person disagree and quarrel?

\begin{tabular}{|c|c|c|c|c|c|c|c|c|c|c|c|}
\hline & $\begin{array}{l}\text { Little } \\
\text { or } \\
\text { None }\end{array}$ & $\begin{array}{l}\text { Some- } \\
\text { what }\end{array}$ & $\begin{array}{l}\text { Very } \\
\text { Much }\end{array}$ & $\begin{array}{l}\text { Extre- } \\
\text { mely } \\
\text { Much }\end{array}$ & $\begin{array}{l}\text { The } \\
\text { Most }\end{array}$ & $\begin{array}{l}\text { Little } \\
\text { or } \\
\text { None }\end{array}$ & $\begin{array}{l}\text { Some- } \\
\text { what }\end{array}$ & $\begin{array}{l}\text { Very } \\
\text { Much }\end{array}$ & $\begin{array}{l}\text { Extre- } \\
\text { mely } \\
\text { Much }\end{array}$ & $\begin{array}{l}\text { The } \\
\text { Most }\end{array}$ & \\
\hline Mother & 1 & 2 & 3 & 4 & 5 & 1 & 2 & 3 & 4 & 5 & Boy/Girl Friend \\
\hline Father & 1 & 2 & 3 & 4 & 5 & 1 & 2 & 3 & 4 & 5 & Same-Sex Friend \\
\hline Sibling & 1 & 2 & 3 & 4 & 5 & 1 & 2 & 3 & 4 & 5 & Other-Sex Friend \\
\hline Relative & 1 & 2 & 3 & 4 & 5 & 1 & 2 & 3 & 4 & 5 & Extra Person \\
\hline
\end{tabular}

21. How much does this person help you figure out or fix things?

\begin{tabular}{|c|c|c|c|c|c|c|c|c|c|c|c|}
\hline & $\begin{array}{l}\text { Little } \\
\text { or } \\
\text { None }\end{array}$ & $\begin{array}{l}\text { Some- } \\
\text { what }\end{array}$ & $\begin{array}{l}\text { Very } \\
\text { Much }\end{array}$ & $\begin{array}{l}\text { Extre- } \\
\text { mely } \\
\text { Much }\end{array}$ & $\begin{array}{l}\text { The } \\
\text { Most }\end{array}$ & $\begin{array}{l}\text { Little } \\
\text { or } \\
\text { None }\end{array}$ & $\begin{array}{l}\text { Some- } \\
\text { what }\end{array}$ & $\begin{array}{l}\text { Very } \\
\text { Much }\end{array}$ & $\begin{array}{l}\text { Extre- } \\
\text { mely } \\
\text { Much }\end{array}$ & $\begin{array}{l}\text { The } \\
\text { Most }\end{array}$ & \\
\hline Mother & 1 & 2 & 3 & 4 & 5 & 1 & 2 & 3 & 4 & 5 & Boy/Girl Friend \\
\hline Father & 1 & 2 & 3 & 4 & 5 & 1 & 2 & 3 & 4 & 5 & Same-Sex Friend \\
\hline Sibling & 1 & 2 & 3 & 4 & 5 & 1 & 2 & 3 & 4 & 5 & Other-Sex Friend \\
\hline Relative & 1 & 2 & 3 & 4 & 5 & 1 & 2 & 3 & 4 & 5 & Extra Person \\
\hline
\end{tabular}


22. How much do you and this person get annoyed with each other's behavior?

\begin{tabular}{|c|c|c|c|c|c|c|c|c|c|c|c|}
\hline & $\begin{array}{l}\text { Little } \\
\text { or } \\
\text { None }\end{array}$ & $\begin{array}{l}\text { Some- } \\
\text { what }\end{array}$ & $\begin{array}{l}\text { Very } \\
\text { Much }\end{array}$ & $\begin{array}{l}\text { Extre- } \\
\text { mely } \\
\text { Much }\end{array}$ & $\begin{array}{l}\text { The } \\
\text { Most }\end{array}$ & $\begin{array}{l}\text { Little } \\
\text { or } \\
\text { None }\end{array}$ & $\begin{array}{l}\text { Some- } \\
\text { what }\end{array}$ & $\begin{array}{l}\text { Very } \\
\text { Much }\end{array}$ & $\begin{array}{l}\text { Extre- } \\
\text { mely } \\
\text { Much }\end{array}$ & $\begin{array}{l}\text { The } \\
\text { Most }\end{array}$ & \\
\hline Mother & 1 & 2 & 3 & 4 & 5 & 1 & 2 & 3 & 4 & 5 & Boy/Girl Friend \\
\hline Father & 1 & 2 & 3 & 4 & 5 & 1 & 2 & 3 & 4 & 5 & Same-Sex Friend \\
\hline Sibling & 1 & 2 & 3 & 4 & 5 & 1 & 2 & 3 & 4 & 5 & Other-Sex Friend \\
\hline Relative & 1 & 2 & 3 & 4 & 5 & 1 & 2 & 3 & 4 & 5 & Extra Person \\
\hline
\end{tabular}

23. How much do you share your secrets and private feelings with this person?

\begin{tabular}{|c|c|c|c|c|c|c|c|c|c|c|c|}
\hline & $\begin{array}{l}\text { Little } \\
\text { or } \\
\text { None }\end{array}$ & $\begin{array}{l}\text { Some- } \\
\text { what }\end{array}$ & $\begin{array}{l}\text { Very } \\
\text { Much }\end{array}$ & $\begin{array}{l}\text { Extre- } \\
\text { mely } \\
\text { Much }\end{array}$ & $\begin{array}{l}\text { The } \\
\text { Most }\end{array}$ & $\begin{array}{l}\text { Little } \\
\text { or } \\
\text { None }\end{array}$ & $\begin{array}{l}\text { Some- } \\
\text { what }\end{array}$ & $\begin{array}{l}\text { Very } \\
\text { Much }\end{array}$ & $\begin{array}{l}\text { Extre- } \\
\text { mely } \\
\text { Much }\end{array}$ & $\begin{array}{l}\text { The } \\
\text { Most }\end{array}$ & \\
\hline Mother & 1 & 2 & 3 & 4 & 5 & 1 & 2 & 3 & 4 & 5 & Boy/Girl Friend \\
\hline Father & 1 & 2 & 3 & 4 & 5 & 1 & 2 & 3 & 4 & 5 & Same-Sex Friend \\
\hline Sibling & 1 & 2 & 3 & 4 & 5 & 1 & 2 & 3 & 4 & 5 & Other-Sex Friend \\
\hline Relative & 1 & 2 & 3 & 4 & 5 & 1 & 2 & 3 & 4 & 5 & Extra Person \\
\hline
\end{tabular}

24. How much do you protect and look out for this person?

\begin{tabular}{|c|c|c|c|c|c|c|c|c|c|c|c|}
\hline & $\begin{array}{l}\text { Little } \\
\text { or } \\
\text { None }\end{array}$ & $\begin{array}{l}\text { Some- } \\
\text { what }\end{array}$ & $\begin{array}{l}\text { Very } \\
\text { Much }\end{array}$ & $\begin{array}{l}\text { Extre- } \\
\text { mely } \\
\text { Much }\end{array}$ & $\begin{array}{l}\text { The } \\
\text { Most }\end{array}$ & $\begin{array}{c}\text { Little } \\
\text { or } \\
\text { None }\end{array}$ & $\begin{array}{l}\text { Some- } \\
\text { what }\end{array}$ & $\begin{array}{l}\text { Very } \\
\text { Much }\end{array}$ & $\begin{array}{l}\text { Extre- } \\
\text { mely } \\
\text { Much }\end{array}$ & $\begin{array}{l}\text { The } \\
\text { Most }\end{array}$ & \\
\hline Mother & 1 & 2 & 3 & 4 & 5 & 1 & 2 & 3 & 4 & 5 & Boy/Girl Friend \\
\hline Father & 1 & 2 & 3 & 4 & 5 & 1 & 2 & 3 & 4 & 5 & Same-Sex Friend \\
\hline Sibling & 1 & 2 & 3 & 4 & 5 & 1 & 2 & 3 & 4 & 5 & Other-Sex Friend \\
\hline Relative & 1 & 2 & 3 & 4 & 5 & 1 & 2 & 3 & 4 & 5 & Extra Person \\
\hline
\end{tabular}

25. How much does this person really care about you?

\begin{tabular}{|c|c|c|c|c|c|c|c|c|c|c|c|}
\hline & $\begin{array}{l}\text { Little } \\
\text { or } \\
\text { None }\end{array}$ & $\begin{array}{l}\text { Some- } \\
\text { what }\end{array}$ & $\begin{array}{l}\text { Very } \\
\text { Much }\end{array}$ & $\begin{array}{l}\text { Extre- } \\
\text { mely } \\
\text { Much }\end{array}$ & $\begin{array}{l}\text { The } \\
\text { Most }\end{array}$ & $\begin{array}{l}\text { Little } \\
\text { or } \\
\text { None }\end{array}$ & $\begin{array}{l}\text { Some- } \\
\text { what }\end{array}$ & $\begin{array}{l}\text { Very } \\
\text { Much }\end{array}$ & $\begin{array}{l}\text { Extre- } \\
\text { mely } \\
\text { Much }\end{array}$ & $\begin{array}{l}\text { The } \\
\text { Most }\end{array}$ & \\
\hline Mother & 1 & 2 & 3 & 4 & 5 & 1 & 2 & 3 & 4 & 5 & Boy/Girl Friend \\
\hline Father & 1 & 2 & 3 & 4 & 5 & 1 & 2 & 3 & 4 & 5 & Same-Sex Friend \\
\hline Sibling & 1 & 2 & 3 & 4 & 5 & 1 & 2 & 3 & 4 & 5 & Other-Sex Friend \\
\hline Relative & 1 & 2 & 3 & 4 & 5 & 1 & 2 & 3 & 4 & 5 & Extra Person \\
\hline
\end{tabular}

26. How much does this person treat you like you're good at many things? 


\begin{tabular}{lccccc||cccccc} 
& $\begin{array}{c}\text { Little } \\
\text { or } \\
\text { None }\end{array}$ & $\begin{array}{c}\text { Some- } \\
\text { what }\end{array}$ & $\begin{array}{c}\text { Very } \\
\text { Much }\end{array}$ & $\begin{array}{c}\text { Extre- } \\
\text { mely } \\
\text { Much }\end{array}$ & $\begin{array}{c}\text { The } \\
\text { Most }\end{array}$ & $\begin{array}{c}\text { Little } \\
\text { or } \\
\text { None }\end{array}$ & $\begin{array}{c}\text { Some- } \\
\text { what }\end{array}$ & $\begin{array}{c}\text { Very } \\
\text { Much }\end{array}$ & $\begin{array}{c}\text { Extre- } \\
\text { mely } \\
\text { Much }\end{array}$ & $\begin{array}{c}\text { The } \\
\text { Most }\end{array}$ & \\
Mother & 1 & 2 & 3 & 4 & 5 & 1 & 2 & 3 & 4 & 5 & Boy/Girl Friend \\
Father & 1 & 2 & 3 & 4 & 5 & 1 & 2 & 3 & 4 & 5 & Same-Sex Friend \\
Sibling & 1 & 2 & 3 & 4 & 5 & 1 & 2 & 3 & 4 & 5 & Other-Sex Friend \\
Relative & 1 & 2 & 3 & 4 & 5 & 1 & 2 & 3 & 4 & 5 & Extra Person \\
\hline
\end{tabular}

27. Between you and this person, who tends to be the BOSS in this relationship?

\begin{tabular}{|c|c|c|c|c|c|c|c|c|c|c|c|}
\hline & $\begin{array}{l}\text { S/he } \\
\text { always } \\
\text { does }\end{array}$ & $\begin{array}{l}\mathrm{S} / \mathrm{he} \\
\text { often } \\
\text { does }\end{array}$ & $\begin{array}{l}\text { About } \\
\text { the } \\
\text { same }\end{array}$ & $\begin{array}{l}\text { I often } \\
\text { do }\end{array}$ & $\begin{array}{c}\text { I } \\
\text { always } \\
\text { do }\end{array}$ & $\begin{array}{l}\text { S/he } \\
\text { always } \\
\text { does }\end{array}$ & $\begin{array}{l}\text { S/he } \\
\text { often } \\
\text { does }\end{array}$ & $\begin{array}{l}\text { About } \\
\text { the } \\
\text { same }\end{array}$ & $\begin{array}{l}\text { I often } \\
\text { do }\end{array}$ & $\begin{array}{l}\text { I } \\
\text { always } \\
\text { do }\end{array}$ & \\
\hline Mother & 1 & 2 & 3 & 4 & 5 & 1 & 2 & 3 & 4 & 5 & Boy/Girl Friend \\
\hline Father & 1 & 2 & 3 & 4 & 5 & 1 & 2 & 3 & 4 & 5 & Same-Sex Friend \\
\hline Sibling & 1 & 2 & 3 & 4 & 5 & 1 & 2 & 3 & 4 & 5 & Other-Sex Friend \\
\hline Relative & 1 & 2 & 3 & 4 & 5 & 1 & 2 & 3 & 4 & 5 & Extra Person \\
\hline
\end{tabular}

28. How sure are you that your relationship will last in spite of fights?

\begin{tabular}{|c|c|c|c|c|c|c|c|c|c|c|c|}
\hline & $\begin{array}{l}\text { Little } \\
\text { or } \\
\text { None }\end{array}$ & $\begin{array}{l}\text { Some- } \\
\text { what }\end{array}$ & $\begin{array}{l}\text { Very } \\
\text { Much }\end{array}$ & $\begin{array}{l}\text { Extre- } \\
\text { mely } \\
\text { Much }\end{array}$ & $\begin{array}{l}\text { The } \\
\text { Most }\end{array}$ & $\begin{array}{l}\text { Little } \\
\text { or } \\
\text { None }\end{array}$ & $\begin{array}{l}\text { Some- } \\
\text { what }\end{array}$ & $\begin{array}{l}\text { Very } \\
\text { Much }\end{array}$ & $\begin{array}{l}\text { Extre- } \\
\text { mely } \\
\text { Much }\end{array}$ & $\begin{array}{l}\text { The } \\
\text { Most }\end{array}$ & \\
\hline Mother & 1 & 2 & 3 & 4 & 5 & 1 & 2 & 3 & 4 & 5 & Boy/Girl Friend \\
\hline Father & 1 & 2 & 3 & 4 & 5 & 1 & 2 & 3 & 4 & 5 & Same-Sex Friend \\
\hline Sibling & 1 & 2 & 3 & 4 & 5 & 1 & 2 & 3 & 4 & 5 & Other-Sex Friend \\
\hline Relative & 1 & 2 & 3 & 4 & 5 & 1 & 2 & 3 & 4 & 5 & Extra Person \\
\hline 9. How & $\begin{array}{l}\text { go pla } \\
\text { Little } \\
\text { or } \\
\text { None }\end{array}$ & $\begin{array}{l}\text { es and } \\
\text { Some- } \\
\text { what }\end{array}$ & $\begin{array}{l}\text { do enj } \\
\text { Very } \\
\text { Much }\end{array}$ & $\begin{array}{l}\text { yable } \\
\text { Extre- } \\
\text { mely } \\
\text { Much }\end{array}$ & $\begin{array}{l}\text { ings v } \\
\text { The } \\
\text { Most }\end{array}$ & $\begin{array}{l}\text { th this } \\
\text { Little } \\
\text { or } \\
\text { None }\end{array}$ & $\begin{array}{l}\text { persor } \\
\text { Some- } \\
\text { what }\end{array}$ & $\begin{array}{l}\text { Very } \\
\text { Much }\end{array}$ & $\begin{array}{l}\text { Extre- } \\
\text { mely } \\
\text { Much }\end{array}$ & $\begin{array}{l}\text { The } \\
\text { Most }\end{array}$ & \\
\hline Mother & 1 & 2 & 3 & 4 & 5 & 1 & 2 & 3 & 4 & 5 & Boy/Girl Friend \\
\hline Father & 1 & 2 & 3 & 4 & 5 & 1 & 2 & 3 & 4 & 5 & Same-Sex Friend \\
\hline Sibling & 1 & 2 & 3 & 4 & 5 & 1 & 2 & 3 & 4 & 5 & Other-Sex Friend \\
\hline Relative & 1 & 2 & 3 & 4 & 5 & 1 & 2 & 3 & 4 & 5 & Extra Person \\
\hline
\end{tabular}


30. How much do you and this person argue with each other?

\begin{tabular}{|c|c|c|c|c|c|c|c|c|c|c|c|}
\hline & $\begin{array}{l}\text { Little } \\
\text { or } \\
\text { None }\end{array}$ & $\begin{array}{l}\text { Some- } \\
\text { what }\end{array}$ & $\begin{array}{l}\text { Very } \\
\text { Much }\end{array}$ & $\begin{array}{l}\text { Extre- } \\
\text { mely } \\
\text { Much }\end{array}$ & $\begin{array}{l}\text { The } \\
\text { Most }\end{array}$ & $\begin{array}{l}\text { Little } \\
\text { or } \\
\text { None }\end{array}$ & $\begin{array}{l}\text { Some- } \\
\text { what }\end{array}$ & $\begin{array}{l}\text { Very } \\
\text { Much }\end{array}$ & $\begin{array}{l}\text { Extre- } \\
\text { mely } \\
\text { Much }\end{array}$ & $\begin{array}{l}\text { The } \\
\text { Most }\end{array}$ & \\
\hline Mother & 1 & 2 & 3 & 4 & 5 & 1 & 2 & 3 & 4 & 5 & Boy/Girl Friend \\
\hline Father & 1 & 2 & 3 & 4 & 5 & 1 & 2 & 3 & 4 & 5 & Same-Sex Friend \\
\hline Sibling & 1 & 2 & 3 & 4 & 5 & 1 & 2 & 3 & 4 & 5 & Other-Sex Friend \\
\hline Relative & 1 & 2 & 3 & 4 & 5 & 1 & 2 & 3 & 4 & 5 & Extra Person \\
\hline
\end{tabular}

31. How often does this person help you when you need to get something done?

\begin{tabular}{|c|c|c|c|c|c|c|c|c|c|c|c|}
\hline & $\begin{array}{l}\text { Little } \\
\text { or } \\
\text { None }\end{array}$ & $\begin{array}{l}\text { Some- } \\
\text { what }\end{array}$ & $\begin{array}{l}\text { Very } \\
\text { Much }\end{array}$ & $\begin{array}{l}\text { Extre- } \\
\text { mely } \\
\text { Much }\end{array}$ & $\begin{array}{l}\text { The } \\
\text { Most }\end{array}$ & $\begin{array}{l}\text { Little } \\
\text { or } \\
\text { None }\end{array}$ & $\begin{array}{l}\text { Some- } \\
\text { what }\end{array}$ & $\begin{array}{l}\text { Very } \\
\text { Much }\end{array}$ & $\begin{array}{l}\text { Extre- } \\
\text { mely } \\
\text { Much }\end{array}$ & $\begin{array}{l}\text { The } \\
\text { Most }\end{array}$ & \\
\hline Mother & 1 & 2 & 3 & 4 & 5 & 1 & 2 & 3 & 4 & 5 & Boy/Girl Friend \\
\hline Father & 1 & 2 & 3 & 4 & 5 & 1 & 2 & 3 & 4 & 5 & Same-Sex Friend \\
\hline Sibling & 1 & 2 & 3 & 4 & 5 & 1 & 2 & 3 & 4 & 5 & Other-Sex Friend \\
\hline Relative & 1 & 2 & 3 & 4 & 5 & 1 & 2 & 3 & 4 & 5 & Extra Person \\
\hline
\end{tabular}

32. How much do you and this person hassle or nag one another?

\begin{tabular}{|c|c|c|c|c|c|c|c|c|c|c|c|}
\hline & $\begin{array}{l}\text { Little } \\
\text { or } \\
\text { None }\end{array}$ & $\begin{array}{l}\text { Some- } \\
\text { what }\end{array}$ & $\begin{array}{l}\text { Very } \\
\text { Much }\end{array}$ & $\begin{array}{l}\text { Extre- } \\
\text { mely } \\
\text { Much }\end{array}$ & $\begin{array}{l}\text { The } \\
\text { Most }\end{array}$ & $\begin{array}{l}\text { Little } \\
\text { or } \\
\text { None }\end{array}$ & $\begin{array}{l}\text { Some- } \\
\text { what }\end{array}$ & $\begin{array}{l}\text { Very } \\
\text { Much }\end{array}$ & $\begin{array}{l}\text { Extre- } \\
\text { mely } \\
\text { Much }\end{array}$ & $\begin{array}{l}\text { The } \\
\text { Most }\end{array}$ & \\
\hline Mother & 1 & 2 & 3 & 4 & 5 & 1 & 2 & 3 & 4 & 5 & Boy/Girl Friend \\
\hline Father & 1 & 2 & 3 & 4 & 5 & 1 & 2 & 3 & 4 & 5 & Same-Sex Friend \\
\hline Sibling & 1 & 2 & 3 & 4 & 5 & 1 & 2 & 3 & 4 & 5 & Other-Sex Friend \\
\hline Relative & 1 & 2 & 3 & 4 & 5 & 1 & 2 & 3 & 4 & 5 & Extra Person \\
\hline
\end{tabular}

33. How much do you talk to this person about things that you don't want others to know?

\begin{tabular}{lccccc||cccccc} 
& $\begin{array}{c}\text { Little } \\
\text { or } \\
\text { None }\end{array}$ & $\begin{array}{l}\text { Some- } \\
\text { what }\end{array}$ & $\begin{array}{c}\text { Very } \\
\text { Much }\end{array}$ & $\begin{array}{c}\text { Extre- } \\
\text { mely } \\
\text { Much }\end{array}$ & $\begin{array}{c}\text { The } \\
\text { Most }\end{array}$ & $\begin{array}{c}\text { Little } \\
\text { or } \\
\text { None }\end{array}$ & $\begin{array}{c}\text { Some- } \\
\text { what }\end{array}$ & $\begin{array}{c}\text { Very } \\
\text { Much }\end{array}$ & $\begin{array}{c}\text { Extre- } \\
\text { mely } \\
\text { Much }\end{array}$ & $\begin{array}{c}\text { The } \\
\text { Most }\end{array}$ & \\
Mother & 1 & 2 & 3 & 4 & 5 & 1 & 2 & 3 & 4 & 5 & Boy/Girl Friend \\
Father & 1 & 2 & 3 & 4 & 5 & 1 & 2 & 3 & 4 & 5 & Same-Sex Friend \\
Sibling & 1 & 2 & 3 & 4 & 5 & 1 & 2 & 3 & 4 & 5 & Other-Sex Friend \\
Relative & 1 & 2 & 3 & 4 & 5 & 1 & 2 & 3 & 4 & 5 & Extra Person \\
& & & & & & & & & & &
\end{tabular}


34. How much do you take care of this person?

\begin{tabular}{|c|c|c|c|c|c|c|c|c|c|c|c|}
\hline & $\begin{array}{l}\text { Little } \\
\text { or } \\
\text { None }\end{array}$ & $\begin{array}{l}\text { Some- } \\
\text { what }\end{array}$ & $\begin{array}{l}\text { Very } \\
\text { Much }\end{array}$ & $\begin{array}{l}\text { Extre- } \\
\text { mely } \\
\text { Much }\end{array}$ & $\begin{array}{l}\text { The } \\
\text { Most }\end{array}$ & $\begin{array}{l}\text { Little } \\
\text { or } \\
\text { None }\end{array}$ & $\begin{array}{l}\text { Some- } \\
\text { what }\end{array}$ & $\begin{array}{l}\text { Very } \\
\text { Much }\end{array}$ & $\begin{array}{l}\text { Extre- } \\
\text { mely } \\
\text { Much }\end{array}$ & $\begin{array}{l}\text { The } \\
\text { Most }\end{array}$ & \\
\hline Mother & 1 & 2 & 3 & 4 & 5 & 1 & 2 & 3 & 4 & 5 & Boy/Girl Friend \\
\hline Father & 1 & 2 & 3 & 4 & 5 & 1 & 2 & 3 & 4 & 5 & Same-Sex Friend \\
\hline Sibling & 1 & 2 & 3 & 4 & 5 & 1 & 2 & 3 & 4 & 5 & Other-Sex Friend \\
\hline Relative & 1 & 2 & 3 & 4 & 5 & 1 & 2 & 3 & 4 & 5 & Extra Person \\
\hline
\end{tabular}

35. How much does this person have a strong feeling of affection (loving or liking) toward you?

\begin{tabular}{lccccc||cccccc} 
& $\begin{array}{c}\text { Little } \\
\text { or } \\
\text { None }\end{array}$ & $\begin{array}{c}\text { Some- } \\
\text { what }\end{array}$ & $\begin{array}{c}\text { Very } \\
\text { Much }\end{array}$ & $\begin{array}{c}\text { Extre- } \\
\text { mely } \\
\text { Much }\end{array}$ & $\begin{array}{c}\text { The } \\
\text { Most }\end{array}$ & $\begin{array}{c}\text { Little } \\
\text { or } \\
\text { None }\end{array}$ & $\begin{array}{c}\text { Some- } \\
\text { what }\end{array}$ & $\begin{array}{c}\text { Very } \\
\text { Much }\end{array}$ & $\begin{array}{c}\text { Extre- } \\
\text { mely } \\
\text { Much }\end{array}$ & $\begin{array}{c}\text { The } \\
\text { Most }\end{array}$ & \\
Mother & 1 & 2 & 3 & 4 & 5 & 1 & 2 & 3 & 4 & 5 & Boy/Girl Friend \\
Father & 1 & 2 & 3 & 4 & 5 & 1 & 2 & 3 & 4 & 5 & Same-Sex Friend \\
Sibling & 1 & 2 & 3 & 4 & 5 & 1 & 2 & 3 & 4 & 5 & Other-Sex Friend \\
Relative & 1 & 2 & 3 & 4 & 5 & 1 & 2 & 3 & 4 & 5 & Extra Person \\
\hline
\end{tabular}

36. How much does this person like or approve of the things you do?

\begin{tabular}{|c|c|c|c|c|c|c|c|c|c|c|c|}
\hline & $\begin{array}{l}\text { Little } \\
\text { or } \\
\text { None }\end{array}$ & $\begin{array}{l}\text { Some- } \\
\text { what }\end{array}$ & $\begin{array}{l}\text { Very } \\
\text { Much }\end{array}$ & $\begin{array}{l}\text { Extre- } \\
\text { mely } \\
\text { Much }\end{array}$ & $\begin{array}{l}\text { The } \\
\text { Most }\end{array}$ & $\begin{array}{l}\text { Little } \\
\text { or } \\
\text { None }\end{array}$ & $\begin{array}{l}\text { Some- } \\
\text { what }\end{array}$ & $\begin{array}{l}\text { Very } \\
\text { Much }\end{array}$ & $\begin{array}{l}\text { Extre- } \\
\text { mely } \\
\text { Much }\end{array}$ & $\begin{array}{l}\text { The } \\
\text { Most }\end{array}$ & \\
\hline Mother & 1 & 2 & 3 & 4 & 5 & 1 & 2 & 3 & 4 & 5 & Boy/Girl Friend \\
\hline Father & 1 & 2 & 3 & 4 & 5 & 1 & 2 & 3 & 4 & 5 & Same-Sex Friend \\
\hline Sibling & 1 & 2 & 3 & 4 & 5 & 1 & 2 & 3 & 4 & 5 & Other-Sex Friend \\
\hline Relative & 1 & 2 & 3 & 4 & 5 & 1 & 2 & 3 & 4 & 5 & Extra Person \\
\hline
\end{tabular}

37. In your relationship with this person, who tends to take charge and decide what should be done?

\begin{tabular}{lccccc||cccccc} 
& $\begin{array}{c}\text { S/he } \\
\text { always } \\
\text { does }\end{array}$ & $\begin{array}{c}\text { S/he } \\
\text { often } \\
\text { does }\end{array}$ & $\begin{array}{c}\text { About } \\
\text { the } \\
\text { same }\end{array}$ & $\begin{array}{c}\text { I often } \\
\text { do }\end{array}$ & $\begin{array}{c}\text { I } \\
\text { always } \\
\text { do }\end{array}$ & $\begin{array}{c}\text { S/he } \\
\text { always } \\
\text { does }\end{array}$ & $\begin{array}{c}\text { S/he } \\
\text { often } \\
\text { does }\end{array}$ & $\begin{array}{c}\text { About } \\
\text { the } \\
\text { same }\end{array}$ & $\begin{array}{c}\text { I often } \\
\text { do }\end{array}$ & $\begin{array}{c}\text { I } \\
\text { always } \\
\text { do }\end{array}$ & \\
Father & 1 & 2 & 3 & 4 & 5 & 1 & 2 & 3 & 4 & 5 & Boy/Girl Friend \\
Sibling & 1 & 2 & 3 & 4 & 5 & 1 & 2 & 3 & 4 & 5 & Same-Sex Friend \\
Relative & 1 & 2 & 3 & 4 & 5 & 1 & 2 & 3 & 4 & 5 & Other-Sex Friend \\
& 1 & 2 & 3 & 4 & 5 & 1 & 2 & 3 & 4 & 5 & Extra Person
\end{tabular}


38. How sure are you that your relationship will continue in the years to come?

\begin{tabular}{lccccc||cccccc} 
& $\begin{array}{c}\text { Little } \\
\text { or } \\
\text { None }\end{array}$ & $\begin{array}{c}\text { Some- } \\
\text { what }\end{array}$ & $\begin{array}{c}\text { Very } \\
\text { Much }\end{array}$ & $\begin{array}{c}\text { Extre- } \\
\text { mely } \\
\text { Much }\end{array}$ & $\begin{array}{c}\text { The } \\
\text { Most }\end{array}$ & $\begin{array}{c}\text { Little } \\
\text { or } \\
\text { None }\end{array}$ & $\begin{array}{c}\text { Some- } \\
\text { what }\end{array}$ & $\begin{array}{c}\text { Very } \\
\text { Much }\end{array}$ & $\begin{array}{c}\text { Extre- } \\
\text { mely } \\
\text { Much }\end{array}$ & $\begin{array}{c}\text { The } \\
\text { Most }\end{array}$ & \\
Mother & 1 & 2 & 3 & 4 & 5 & 1 & 2 & 3 & 4 & 5 & Boy/Girl Friend \\
Father & 1 & 2 & 3 & 4 & 5 & 1 & 2 & 3 & 4 & 5 & Same-Sex Friend \\
Sibling & 1 & 2 & 3 & 4 & 5 & 1 & 2 & 3 & 4 & 5 & Other-Sex Friend \\
Relative & 1 & 2 & 3 & 4 & 5 & 1 & 2 & 3 & 4 & 5 & Extra Person \\
\hline
\end{tabular}

39. Earlier, when we asked you to choose your most important same- and other-sex friends, we said that they could not be a sibling or a relative. Now please tell us who, of all these people, is your best friend?
A. My same-sex friend.
B. My opposite-sex friend.
C. My sibling. Name
D. My relative. Name

LISA (Word) ... $\mid$ adol $\backslash q u e s t \backslash n r i . d o c$ 
APPENDIX H
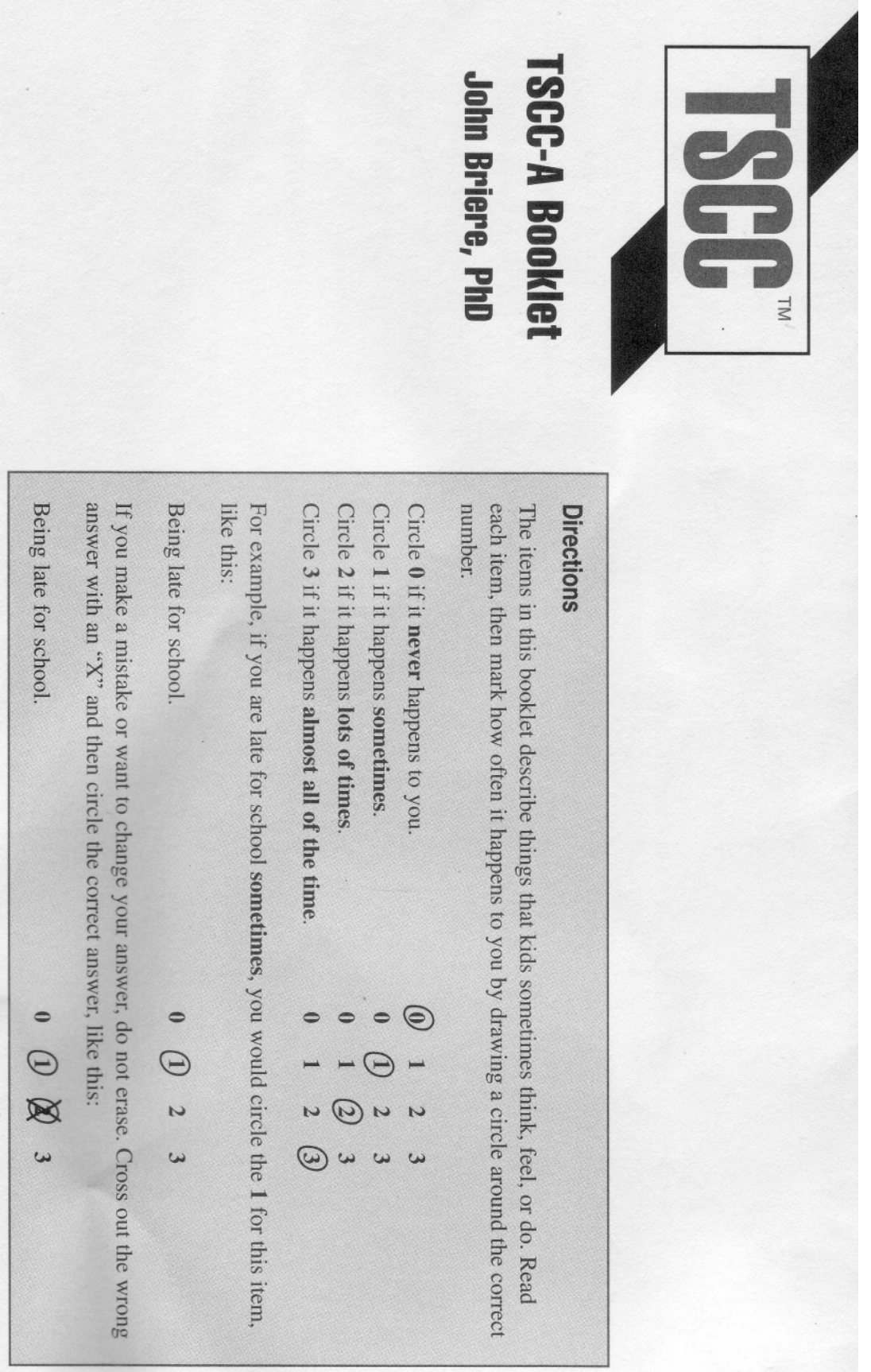


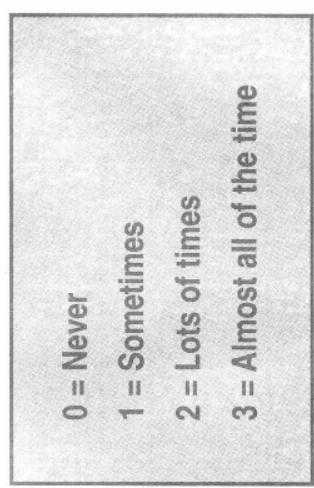

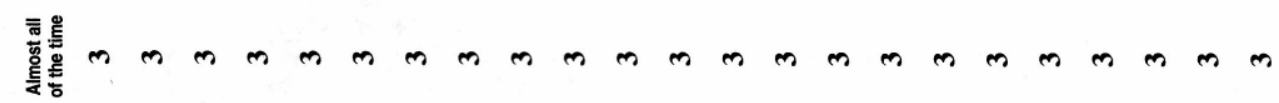

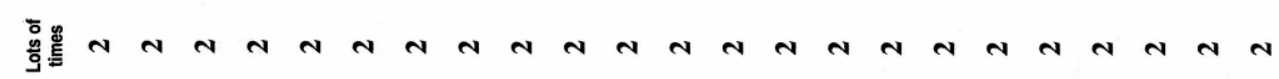
曾 产 000000000000000000000

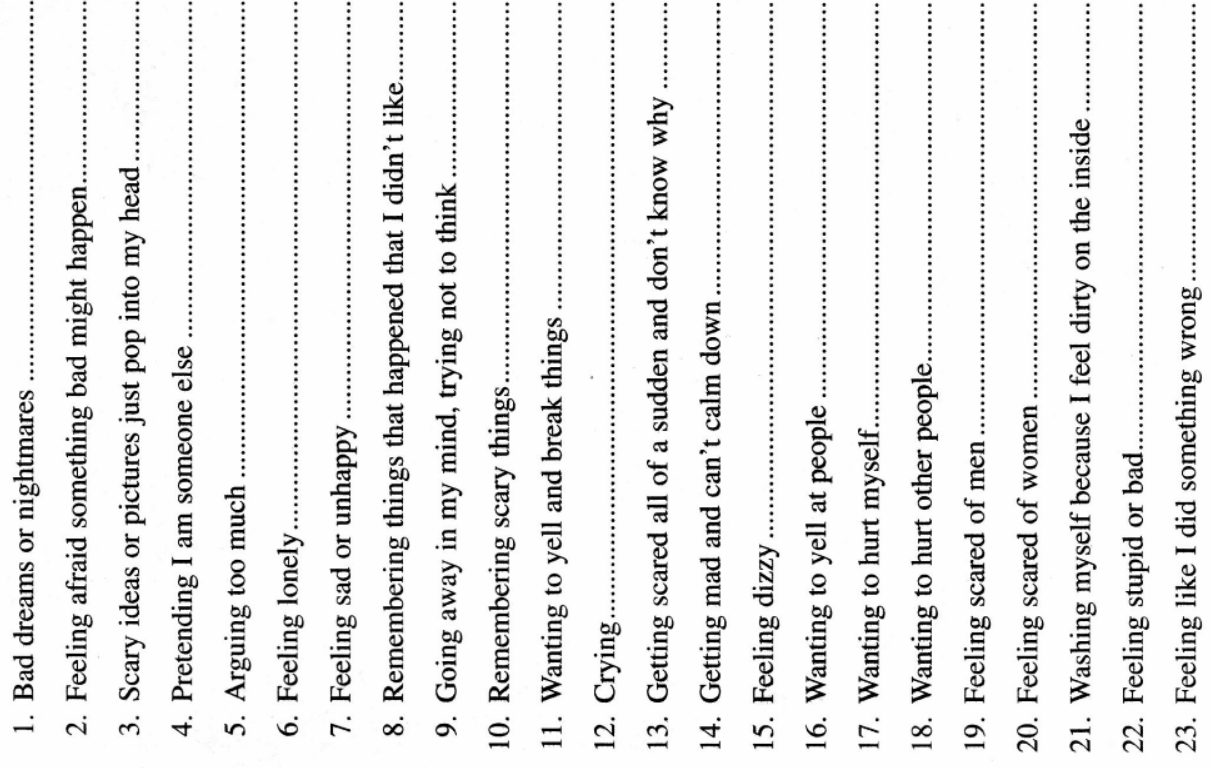




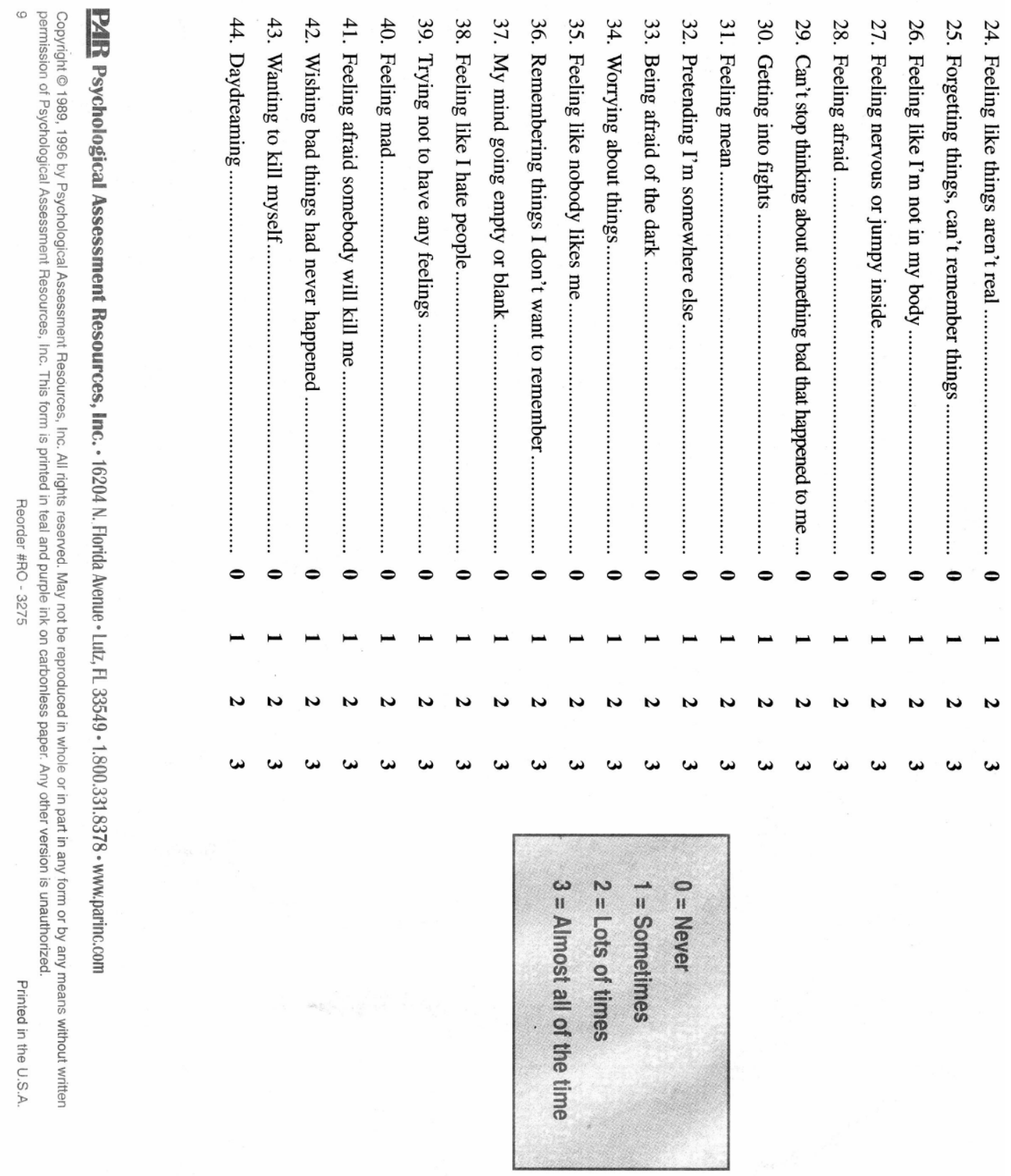




\section{APPENDIX I \\ Aggression Scale}

Please tell us about some things that you did over the last 7 days. You will not get in to trouble for anything that you did or that might have happened. For each question, please tell us how many times you did something during the last 7 days.

\section{Number of Times}

1. I teased other kids to make them angry. $\begin{array}{llllllll}1 & 2 & 3 & 4 & 5 & 6+\end{array}$

2. I got angry very easily with someone. $\quad \begin{array}{lllllllll} & 1 & 2 & 3 & 4 & 5 & 6+\end{array}$

3. I fought back when someone hit me first. $1 \quad \begin{array}{llllllll} & 2 & 3 & 4 & 5 & 6+\end{array}$

4. I said things about other kids to make $\begin{array}{lllllllll}\text { other kids laugh. } & 1 & 2 & 3 & 4 & 5 & 6+\end{array}$

$\begin{array}{llllllllll}\text { 5. I encouraged other kids to fight. } & 1 & 2 & 3 & 4 & 5 & 6+\end{array}$

$\begin{array}{llllllllll}\text { 6. I pushed or shoved other kids. } & 1 & 2 & 3 & 4 & 5 & 6+\end{array}$

$\begin{array}{llllllll}\text { 7. I was angry most of the day. } & 1 & 2 & 3 & 4 & 5 & 6+\end{array}$

8. I got into a physical fight because $\begin{array}{lllllllll}\text { I was angry. } & 1 & 2 & 3 & 4 & 5 & 6+\end{array}$

$\begin{array}{lllllllll}\text { 9. I slapped or kicked someone. } & 1 & 2 & 3 & 4 & 5 & 6+\end{array}$

10. I called other kids bad names $\quad \begin{array}{llllllll}6+\end{array}$

11. I threatened to hurt or hit someone. $\quad \begin{array}{lllllllll} & 1 & 2 & 3 & 4 & 5 & 6+\end{array}$ 


\section{APPENDIX J}

\section{Homeless Experiences Questionnaire for Children $\left(\mathrm{HEQC}^{*}\right)$}

Directions: Different things happen to kids who are homeless. This questionnaire asks about some of the things that may have happened to you since you became homeless. In the first part of the questionnaire, you will be asked to say whether or not something happened to you. In the second part, you will be asked some more questions about how you felt about what happened to you. There are no right or wrong answers to the questions and no one will see the answers to your questions at the shelter where you are staying.

\section{$\underline{\text { Part } 1}$}

This part of the questionnaire tells what happened to you. Answer yes or no if something happened since were homeless.

When you became homeless:

1. Did you lose important toys or stuff?

Yes:

No:

2. Did you stop seeing special friends?

Yes:

No:

3. Did you change schools?

Yes:

No:

4. Have you gone to lots of different schools?

Yes:

No:

5. Have you missed a lot of school?

Yes:

No:

6. Do your teachers treat you differently?

Yes:

No:

7. Do other kids make fun of you?

Yes:

No: 
8. Do other kids bully you?

Yes:

No:

9. Did you stop seeing your aunts, cousins or grandparents?

Yes:

No:

10. Were you told that you might be put in foster care?

Yes:

No:

11. Is there something at your shelter that makes you feel unsafe?

Yes:

No:

12. Have other people at your shelter said or done something to you that was threatening or scary to you?

Yes:

No:

13. Have you had to be separated or apart from your family members because they weren't allowed to stay at your shelter?

Yes:

No:

14. Have your friends not been allowed to visit you at the shelter?

Yes:

No:

15. Have you had to learn a lot of new rules at the shelter?

Yes:

No:

16. Have you had to help your mom in new ways that you weren't used to, such as helping to take care of your brothers and sisters or translating for her?

Yes: No:

17. Since becoming homeless, have you seen your mom behave in ways that you weren't used to or didn't expect?

Yes:

No:

18. Did you have a pet before you were homeless that you had to give away or leave behind?

Yes: No:

\section{Part 2}

This part of the questionnaire is to learn about how you felt about your experiences since becoming homeless. Circle the answer that is most like your feelings. 
1. If you lost important toys and stuff since becoming homeless, how hard was this for you?

Not hard at all A little hard Medium hard Very hard

2. If you stopped seeing special friends since becoming homeless, how hard was this for you?

Not hard at all A little hard Medium hard $\quad$ Very hard

3. If you changed schools since becoming homeless, how hard was this for you?

Not hard at all A little hard Medium hard $\quad$ Very hard

4. If you have gone to a lot of different schools since becoming homeless, how hard was this for you?

Not hard at all A little hard Medium hard $\quad$ Very hard

5 If you have missed a lot of school since becoming homeless, how hard is this for you?

Not hard at all A little hard Medium hard Very hard

6. If your teachers have treated you differently, how hard has this been for you?

Not hard at all A little hard $\quad$ Medium hard $\quad$ Very hard

7. If kids have made fun of you since you became homeless how hard has this been for you?

Not hard at all A little hard Medium hard Very hard

8. If kids have bullied you since you became homeless, how hard has this been for you?

Not hard at all A little hard $\quad$ Medium hard $\quad$ Very hard

9. If you have stopped seeing your aunts, cousins and grandparents since becoming homeless, how hard has this been for you?

Not hard at all A little hard Medium hard Very hard

10. If you were told that you might be put in foster care, how hard was this for you?

Not hard at all A little hard Medium hard Very hard 
11. If there is something at your shelter that makes you feel unsafe, how hard is that for you?
Not hard at all
A little hard
Medium hard
Very hard

12. If someone said something to you at the shelter that made you feel threatened or scared, how hard has that been for you?
Not hard at all
A little hard
Medium hard
Very hard

13. If you have been separated from someone in your family how hard has that been for you?
Not hard at all
A little hard
Medium hard
Very hard

14. If you have not been allowed to have friends visit you in your shelter, how hard has that been for you?

Not hard at all A little hard Medium hard Very hard

15. If you have had to learn a lot of new rules at your shelter, how hard has that been for you?

Not hard at all A little hard Medium hard $\quad$ Very hard

16. If you have had to help your mom in new ways that you weren't used to, how hard has that been for you?

Not hard at all A little hard Medium hard $\quad$ Very hard

17. If your mom has been behaving in a different way that you didn't expect since you became homeless, how hard has this been for you?

Not hard at all A little hard Medium hard $\quad$ Very hard

18. If you had to give away or leave a pet when you became homeless, how hard was that for you?

Not hard at all A little hard Medium hard $\quad$ Very hard

*copyright: Beryl Ann Cowan, Gabriel P. Kuperminc,\& Greg Jurkovic 


\section{APPENDIX K}

\section{Adolescent Stress and Trauma Exposure Questionnaire (Brief Version) \\ ASTEQ-Brief Version}

Directions: Different things happen to kids and teenagers. These cards have things printed on them that might have happened to you. The card will be read aloud to you, and you may read along silently if you can. If the event happened to you at anytime in your life, put the card in the yes pile. If the event never happened to you, put the card in the no pile. After finishing the first part, you will be asked some more questions. The first part takes about 10 minutes to answer, and the second part takes about 5-10 minutes to answer. Remember, there are no right or wrong answers. Simply try your best to remember what happened to you.

\section{Part 1}

*Questions with * only asked where age appropriate.

1. Have you ever been mugged or robbed?

2. Has a robber ever broken into your home?

3. Have any of your brothers or sisters been placed in foster care or jail?

4. Has your mom or dad ever been arrested and put in jail?

5. Have you ever been in a bad accident, like a car accident.

6. Have you ever been arrested or placed in detention?

7. Have you ever been chased by a dog or another animal?

8. Did you ever get so lost that you didn't know how to get home?

9. * Have you ever had a really bad break up with a boyfriend or girlfriend?

10. * Have you ever been pregnant or gotten someone pregnant?

11. Have you ever been around a shooting, drug bust or gang fight?

12. Have you ever been in a fire or had your house damaged by fire?

13. Have you ever been beaten up, bruised or physically hurt by a member of your family or someone taking care of you?

14. Have you ever been shot with a gun or hurt with a knife?

15. Has anyone ever touched you in private places and made you do things that were uncomfortable?

16. Have you been in foster care?

17. Have you ever had trouble trying to get along with your parent's boyfriend or girlfriend or a step-parent?

18. Has anyone tried to hurt themselves or kill themselves when you were with them?

19. Have your seen your parent punch, fight or hit another grown up?

20. Have you ever seen someone not in your family get beaten up or in a fight?

21. Have you ever been really sick and needed to go to the hospital? 
22. Have you ever heard gunshots in your neighborhood?

23. Do kids at your school or neighborhood carry guns or knives ?

24. Has someone who takes care of you, like your Mom, Dad or grandparent ever gotten really sick?

25. Have you ever seen a grown up or someone you know using drugs?

26. Have you ever had a bad experience with a gang?

27. *Have you ever a bad experience when using drugs or alcohol?

28. Have you ever been made to stop living with one parent or relative and sent to live with another parent or relative?

29. Has a parent or family member that you really loved died?

30. Have your parents or caregivers ever hit, choked, pushed or physically hurt each other?

31. Has there been a lot of yelling, fighting, arguing and cursing in your home?

32. Have there been times when your parents or caregivers called you names, put you down or said mean things to you?

33. Have your parents or caregivers ever not taken care of you or paid attention to you for a long time?

34. Has there ever been a time when your parents or caregivers did not help you when you were sick and needed to go to the doctor?

35. Have your parents or caregivers ever left you, thrown you out of your house, or told you that they were going to leave you?

36. *Have you ever had to take a job to help support your family?

37. Have you ever had to break up a fight between your parents or family members?

38.. Have you had to do a lot at home to help your family, like taking care of your sisters and brothers, cleaning, cooking, yard work, fixing things, or doing laundry?

39. Have you ever had to hide to stay safe or to avoid the police or someone who was looking to get you?

40. Have you ever been kidnapped or taken some place against your will?

41. *Have you ever had an abortion or helped someone have an abortion?

42. Have you ever seen someone hurt your brothers or sisters?

43. Has someone who is not one of your family members ever beaten you up, or physically hurt you?

44. Have you ever stayed back in school?

45. Have your parents or relatives argued about who you were going to live with?

ASTEQ Brief Version copyright by Gregory J. Jurkovic, Marla Zucker, Joanna Ball, Samuel Fasulo, Beryl Ann Cowan (2006) 


\section{ASTEQ-Brief Version}

Part 2

Directions: Thank you for completing the first part of this measure. In the second part, you will be asked to pick the 5 things that stressed you out or upset you the most and then put them in the pile. If you want to, you can go back in the pile to look through the cards more than once until you decide the top 5 things that upset you or stressed you out the most. Remember, there are no right or wrong answers. Just try to answer the questions the best you can.

Item\#

$\begin{array}{cl}- & \text { check all that apply } \\ - & \text { Young child(0-6) } \\ - & \text { Older child (7-12) } \\ - & \text { Teen-now(13-now) } \\ & \\ - & \text { Young child(0-6) } \\ - & \text { Older child (7-12) } \\ - & \text { Teen-now (13-now) } \\ & \text { Young child (0-6) } \\ - & \text { Older child(7-12) } \\ - & \text { Teen (13-now) } \\ - & \text { Young child (0-6) } \\ - & \text { Older Child (7-12) } \\ - & \text { Teen (13-now) } \\ - & \text { Young child( 0-6) } \\ - & \text { Older child (7-12) } \\ - & \text { Teen(13 -now) }\end{array}$

\section{How many times Did it happen? \\ What's the most \\ That it scared you}

circle one

$1-2 x$

3-5x

6 or morex

$1-2 \mathrm{x}$

$3-5 x$

6 or morex

1-2x

3-5x

6 or morex

\section{1-2x}

$3-5 x$

6 or morex

1-2x

3-5x

6 or more

$1=$ none

$2=$ some

$3=\mathbf{a}$ lot

$1=$ none

$2=$ some

$3=\mathbf{a}$ lot

$1=$ none

$2=$ some

$3=\mathbf{a}$ lot

$1=$ none

$2=$ some

$3=\mathbf{a}$ lot
How much do you think about it now?

circle one

$\begin{array}{lll}1=\text { none } & \begin{array}{l}1=\text { none } \\ 2=\text { some }\end{array} & \begin{array}{l}1=\text { none } \\ 2=\text { some }\end{array} \\ 2=\text { some } & 3=\text { a lot } & 3=\text { a lot } \\ 3=\text { a lot } & & \end{array}$

1=none

some

$3=\mathbf{a}$ lot

$1=$ none

$2=$ some

$3=\mathbf{a}$ lot

$1=$ none

$2=$ some

$3=\mathbf{a}$ lot

$1=$ none

$2=$ some

$3=\mathbf{a}$ lot
How much have you

You had dreams, feelings, thoughts about this in the last month? circle one

Of these things, what was the worst thing that happened? 


\section{APPENDIX L}

\section{Debriefing Form}

ID Number:

Researcher: Complete this form Before interviewing another youth.

Did the youth express significant concern or distress about any issues related to the measures or process of participation? Yes No

If yes, describe the situation including behavioral observations:

Was further action necessary? Yes No

If yes, please describe:

Please circle the following critical items that were endorsed by the youth ASTEQ brief: $\quad$ \#13 \#15 \#43

Are these events occurring now?

Yes

TSCC-A items endorsed regardless of severity

$$
\text { \#17 }
$$

\#18

\#43

If any of the above critical items are circled, complete a Mental Health Referral Form with the following information: 1) the youth's name 2)check "routine" (any urgent referrals will be extremely rare and will be handled and recorded separately 3 ) under reasons for mental health referral write a statement such as "Yuth endorsed the following statements during a GSU research project : having been physically or sexually abused by a family member/or wanting to kill himself. “ Please keep the MH referral form in a separate pile. Beryl or Greg will sign and date them and turn a copy into the facility at the end of each day of data collection.

Printed name of Research Assistant

\section{Date:}

Action taken:

Beryl Ann Cowan, J.D. ,M.A. 